\title{
Conceptual Flow Sheets Development for Coal Conversion Plant Coal Handling-Preparation and Ash/Slag Removal Operations
}

Bechtel National, Inc.,

OPERATED BY

UNION CARBIDE CORPORATION FOR THE UNITED STATES DEPARTMENT OF ENERGY 


\section{DISCLAIMER}

This report was prepared as an account of work sponsored by an agency of the United States Government. Neither the United States Government nor any agency Thereof, nor any of their employees, makes any warranty, express or implied, or assumes any legal liability or responsibility for the accuracy, completeness, or usefulness of any information, apparatus, product, or process disclosed, or represents that its use would not infringe privately owned rights. Reference herein to any specific commercial product, process, or service by trade name, trademark, manufacturer, or otherwise does not necessarily constitute or imply its endorsement, recommendation, or favoring by the United States Government or any agency thereof. The views and opinions of authors expressed herein do not necessarily state or reflect those of the United States Government or any agency thereof. 


\section{DISCLAIMER}

Portions of this document may be illegible in electronic image products. Images are produced from the best available original document. 


\section{Printed in the United States of America. Available from National Technical Information Service U.S. Department of Commerce 5285 Port Royal Road, Springfield, Virginıa 22161 NTIS price codes-Printed Copy: All Microfiche A01}

This report was prepared as an account of work sponsored by an agency of the United States Government. Neither the United States Government nor any agency thereof, nor any of their employees, makes any warranty, express or implied, or assumes any legal liability or responsibility for the accuracy, completeness, or usefulness of any information, apparatus, product, or process disclosed, or represents that its use would not infringe privately owned rights. Reference herein to any specific commercial product, process, or service by trade name, trademark, manufacturer, or otherwise, does not necessarily constitute or imply its endorsement, recommendation, or favoring by the United States Government or any agency thereof. The views and opinions of authors expressed herein do not nocessarily state nr reflest those of the United States Government or any agency thereof. 
CONCEPTUAL FLOW SHEETS DEVELOPMENT

FOR COAL CONVERSION PLANT COAL

HANDL ING-PREPARATION AND ASH/SLAG

REMOVAL OPERATIONS

\section{JULY 1979}

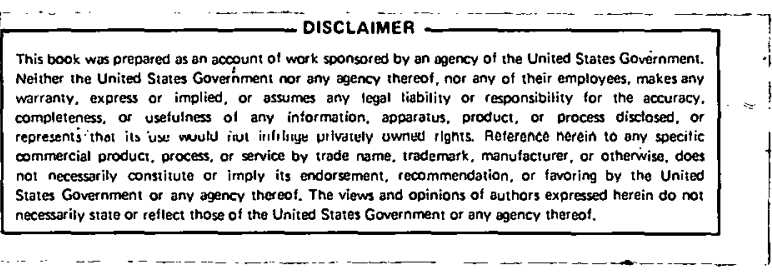

Report prepared by BECHTEL NATIONAL, INC., P.0. Box 3965, San Francisco, CA 94119 under contract number $62 X-45724 \mathrm{~V}$ for OAK RIDGE NATIONAL LABORATORY

Oak Ridge, Tennessee 37830 operated by

UNION CARBIDE CORPORATION for the

DEPARTMENT OF ENERGY 
THIS PAGE

WAS INTENTIONALLY

LEFT BLANK 
CONTENTS

Section

Page

1

ABSTRACT

$1-1$

2

SUMMARY

$2-1$

CONCLUSIONS

$3-1$

CONCEPTUAL FLOW SILEET3 BASES AND DEVELUPMEN'I' APPROACH

4-1

4.1 Introduction 4-1

4.2 Conceptual Flow Sheets Bases 4-3

4.2.1 Conversion Plants Design Feed Coal Characteristics $\quad 4-3$

4.2.2 Coal Conversion Plant Coarse Coal Inlet Boundaries

4-5

4.2.3 Coal Conversion Processes

$4-6$

4.2.4 Coal Conversion Processes Coal and Ash/S1ag Handling Boundaries 4-24

4.2.5 Coal Cleaning 4-27

4.2.6 Power/Steam Plant Coal Requirements 4-39

4.3 Conceptual Flow Sheets Development Approach 4-40

4.3.1 Coal Cleaning 4-48

4.3.2 Coal Storage and Blending 4-49

4.3.3 Coal Fine Crushing 4-51

4.3.4 Coal Pulverizing and Grinding 4-52

4.3.5 Conversion Reactor Ash/Slag Removal 4-53

5.1 Flow Sheets and Major Equipment Lists General Qualifications

$5-2$

\section{Preceding page blank}


5.2 Coal Cleaning Conceptual Flow Sheets 5-8

5.2.1 Coarse Coal Breaking, Cleaning, $5-8$ and Crushing 5-8

5.2.2 Fine Coal Cleaning and Dewatering 5-20

5.2.3 Coal Cleaning Effluent Treatment 5-31

5.3 Coal Storage and Blending Conceptual 5-33
Flow Sheets

5.4 Coal Fine Crushing Conceptual. Flow Sheets 5-48

5.4.1 Coal Finc Crushing Without U1trafines Removal $\quad 5-55$

5.4.2 $\frac{\text { Coal Fine Crushing with U1tra- }}{\text { fines Removal }} \quad$ 5-90

5.5 Coal Pulverizing and Grinding Conceptual 5-101

5.6 Ash/Slag Removal Flow Sheers 5-109

APPENDIX A A $\quad A$

REFERENCES R R 
TABLES

$\underline{\text { Table }}$

Coal Conversion Processes Summary

$2-2$

$4-1$

Coal Conversion Processes Coal Feed Requirements

$4-7$

4-2

Coal Conversion Processes Ash/Slag Removal Systems Design Information

$4-13$

$4-3$

Selected Coal Ash Analysis and Fusion Temperatures

$4=22$

$4-4$

Typical Illinois No. 5 Coal Ash Fusion Temperatures Reduring Atmosphere

$$
\text { 4-25 }
$$

4-5 Pittsburgh Seam Coal Washab1lity Characteristics Without Roof and Floor Dilution

$4-28$

4-6 Pittsburgh Seam Coal Washability Characteristics With Roof and Floor Dilution

$4-29$

4-7 Kentucky No. 9 Seam Coal Washability Characteristics Without Roof and Floor Dilution

4-8 Kentucky No. 9 Seam Coal Washability Characterisitcs With Roof and Floor Dilution

Coal Cleaning Flow Sheets Design Conditions

Selected Coal Conversion Processes Estimated Electricity and Steam Requirements

4-11 Estimated Gasification Ash and Granulated Slag Characteristics

5-1 Live Coal Storage Alternatives Summary 
THIS PAGE

\section{WAS INTENTIONALLY \\ LEFT BLANK}




\section{FIGURES}

$\underline{\text { Figure }}$

Page

4-1 Forecast of Ash-Softening Temperatures of Pittsburgh Seam Coal

4-2 Pittsburgh Seam Coal Washability Characterisitcs Without Roof And Floor Dilution

4-3 Pittsburgh Seam Coal Washability Characteristics With Ronf And Floor Dilutiun

4-4 Kentucky No. 9 Seam Coal Washability Characteristics Without Roof And Floor Dilution

Kentucky No. 9 Seam Coal Washability Characteristics With Roof And Floor Dilution

Estimated Broken Coal Size Consist 
THIS PAGE

WAS INTENTIONALLY

LEFT BLANK 
LIST OF FLOW SHEETS AND EQUIPMENT LISTS

Number

Page

FS- 1 JIG COARSE AND FINE COAL CLEANING

$5-9$

FS $-1-1$

ALTERNATIVE: HYDROCYCLONE FINE COAL CLEANING

$5-21$

FS $-1-2$

ALTERNATIVE: TABLE FINE COAL CLEANING

$5-25$

FS-2-1

ALTERNATIVE COARSE COAL LIVF STORAGE - V-BUNKERS

$5-43$

FS -3

SINGT.F STACE CAGE MILL COAL FINE CRUSIIING 3RC I AND II, EXXON DONOR SOLVENT, AND EXXON CATALYTIC GASIFICATION

FS-4 TWO STAGE CACE MILL COAL FINE CRUSHING HYGAS AND TEXACO PARTIAL OXIDATION

$5-63$

FS-4-1 ALTERNATIVE: TWO STAGE CAGE MILL COAL FINE CRUSHING STACKED ARRANGEMENT HYGAS AND TEXACO PARTIAL OXIDATION

$5-67$

FS-5 ALTERNATIVE: SINGLE STAGE CAGE MILL CLOSED CIRCUIT COAL FINE CRUSHING TO MINIMIZE ULTRAFINES PRODUCTION

$5-71$

FS-6 SINGLE STAGE CAGE MILL COAL FINE CRUSHING U-GAS AND COGAS

$5-79$

FS-7 COARSE COAL THERMAL DRYING

$5-83$

FS-8 ALTERNATIVE: SINGLE STAGE CAGE MILL COAL FINE CRUSHING WITH PRE-SCREENING U-GAS

FS-9

FINE COAL ULTRAFINES SEPARATION

$5-93$

FS-10 ROD MILL COAL WET GRINDING TEXACO PARTIAL OXIDATION

$5-97$

FS-11 SOLVENT COAL GRINDING H-COAL PROCESS

5-105

FS-12

ASH AND SLAG DEWATERTNG AND TRANSPORT

$5-111$

FS -13

ASH AND SLAG SLURRY PIPELINE TRANSPORT

5-119

\section{Preceding page blank ix}


Section 1

ABSTRACT

This report presents 14 conceptual flow sheets and major equipment lists for coal handling and preparation operations that could be required for future, commercial coal conversion plants. These flow sheets are based on converting 50,000 tons per day of clean coal representative of the Pittsburgh and Kentucky No. 9 coal seams. Flow sheets were used by Union Carbide Corporation, Oak Ridge National Laboratory, in a survey of coal handling/preparation equipment requirements for future coal conversion plants. Operations covered in this report include run-of-mine coal breaking, coarse coal cleaning, fine coal cleaning, live storage and blending, fine crushing (crushing to top sizes ranging from $1 / 4-i n c h$ to 20 mesh), drying, and grinding (70 percent minus 200 mesh).

Two conceptual flow sheets and major equipment lists are also presented for handling ash or granulated slag and other solid wastes produced by nine leading coal conversion processes. These flow sheets provide for solid wastes transport to an environmentally acceptable disposal site as either dry solids or as a water slurry. 
Section 2

SUMMARY

Union Carbide Corporation - Nuclear Division, Oak Ridge National Laboratory, is conducting a survey of coal handling, coal preparation, and ash/slag removal equipment requirements for future, commercial-scale coal conversion plants. Thie rcquirements survey is being pertormed for the Department of Energy (DOE), Fossil Energy. It is part of a major DOE program to establish equipment requirements for largc-3cale conversion plants and to determine the capabilities of manufacturers to provide such equipment.

In order to efficiently identify equipment for inclusion in their requirements survey, Union Carbide contracted with Bechtel National, Inc. for development of conceptual commercial coal conversion plant coal handlingpreparation and ash/slag removal flow sheets and major equipment lists. This report presents the resulting conceptual flow sheets and major equipment lists. It also presents the bases and development approach used in their preparation. Coal preparation operations covered by these flow sheets are run-of-mine coal breaking, coarse coal cleaning, coarse coal crushing, fine coal cleaning, live storage-blending, dead storage, fine crushing, and grinding.

All conceptual flow sheets are for coal conversion plants that consume 50,000 short tons per day of coal having a nominal total moisture of 8.0 wt percent. Of this coal quantity, 15 percent is used in an atmospheric pressure fluidized-bed (AFB) power/steam plant which is part of the coal conversion plant. The other 85 percent is provided to conversion 
reactors for the nine coal conversion processes identified in Table 2-1. This table also summarizes reported process conversion reactor coal feed requirements.

Table 2-1

COAT, CONVERSION PROC.F.SSES SUMMARY

\begin{tabular}{|c|c|c|c|}
\hline $\begin{array}{l}\text { Prnress } \\
\text { Number }\end{array}$ & Cunvelsiuñ Proceoc and Type & $\frac{\text { Conversion Reactor Coal }}{\text { S1ze Cullsist }}$ & $\frac{\text { Feed Requirements }}{\text { Moisture }}$ \\
\hline 1 & $\begin{array}{l}\text { U-Gas - Fluidized-Bed } \\
\text { Gasification }\end{array}$ & $\begin{array}{l}100 \text { Percent Minue } 1 / 4 \\
\text { Inch }\end{array}$ & As Received \\
\hline ? & $\begin{array}{l}\text { COGAS - Fluidized-Bed } \\
\text { Gasification }\end{array}$ & $\begin{array}{l}100 \text { Percult Misius } 1 / 4 \\
\text { Inch }\end{array}$ & Ac Reçeived \\
\hline 3 & $\begin{array}{l}\text { HYGAS - Fluidized-Bed } \\
\text { Gasification }\end{array}$ & $\begin{array}{l}100 \text { Percent Minus } \\
14 \text { Mesh }\end{array}$ & As Recelved \\
\hline 4 & $\begin{array}{l}\text { Texaco Partial Oxidation - } \\
\text { Entrained Flow Gasification }\end{array}$ & $\begin{array}{l}100 \text { Percent Minus } \\
20 \text { Mesh }\end{array}$ & As Received \\
\hline 5 & $\begin{array}{l}\text { Exxon Donor Solvent - } \\
\text { Liquefaction }\end{array}$ & $\begin{array}{l}100 \text { Percent Minus } \\
8 \text { Mesh }\end{array}$ & As Received \\
\hline 6 & $\begin{array}{l}\text { Exxon Catalytic Gasifica- } \\
\text { tion- Fluidized-Bed Gasifi- } \\
\text { cation }\end{array}$ & $\begin{array}{l}\text { lou Pércenr. Minus } \\
8 \text { Mesh }\end{array}$ & As Receivad \\
\hline$\underset{8}{7}$ & $\begin{array}{l}\text { SRC-I and SRC-II - Lique- } \\
\text { faction }\end{array}$ & $\begin{array}{l}100 \text { Percent Minus } \\
12 \mathrm{Mesh}\end{array}$ & As Rereived \\
\hline 9 & H-Coal - Liquefaction & $\begin{array}{l}70 \text { Percent Minus } \\
200 \text { Mesh }\end{array}$ & 2.0 Wt Percent \\
\hline
\end{tabular}


Two major bituminous coal seams were specified as possible conversion plant sources:

- Pittsburgh Seam coal as represented by this seam.in Monongalia County, West Virginia

- Kentucky No.9 Seam coal as represented by this seam in Hopkins County, Kentucky

Coal from either seam was postulated to be provided from a coal mine complex located adjacent to the conversion plant site or from regional coal mines located appreciable distances from the plant site. For both coal suulces, the conceptual flow'sheets start at the conversion plant site after coal receiving. The coal operations flow sheets terminate at conversion reactor coal feed systems.

Coal produced from the adjacent coal mine complex can be cleaned and then conveyed to live or dead storage facilities, or not cleaned, and after reduction to 2 inch $\mathrm{x} 0$, conveyed to live or dead storage. Coal transported from regional mines is sized to 2 inch $x 0$, and if justified, cleaned hefore transport in rail cars and/or river barges.

In coal cleaning, coal is broken to 6 inch $x 0$ and wet screened at $3 / 8$ inch. Six-inch $\mathrm{x}$ 3/8-inch coal is cleaned in coarse coal jigs, screen dewatered, and crushed to 2 -inch top size prior to conveying to live or dead storage. Undersize coal and crushed coarse coal jig middlings can be cleaned by selecting any one of three flow sheet processes: jig, hydrocyclone, or table fine coal cleaning. After cleaning, fine coal is dewatered with vibrating centrifuges, mixed with crushed coarse coal, and conveyed to live or dead storage. Effluents from both coarse and fine coal dewatering are treated to separate minus 28 mesh solids and recycle water.

Two methods are identified for live storage-blending following coal cleaning or unloading of coal from regional mines: open, multiple, wedge-shape stockpiles and totally-enclosed V-bunkers. Specified design raparity for 
both methods is 500,000 tons. With this live storage capacity, normal fluctuations between mining or long-distance transport operations and conversion reactor operations can be accommodated without use of a dead storage facility. Dead coal storage, for use in emergency situations, is provided by open, sealed coal piles built and reclaimed by mobile equipment.

With exception of $\mathrm{H}$-Coal, the conversion processes in 'l'able 2-1 reyuire what is defined to be fine coal conversion reactor feed; coal containing particles not greater than $1 / 4$ inch, but not all. amnller than 20 mesh in size. Kerause of the largc number uf pronesaco requiring this coal size and the different size latiges, nine conceptual roal fine crushing flow shcets and major equipment lists are presented. With two exceptions, these flow sheets use multi-row cage mill crushers. The flow sheets provide for:

- Single-stage, open-circuit cage mill fine crushing -SRC-I and SRC-II, Exxon Donor Solvent, Exxon Catalytic Gasification, $\mathrm{U}-\mathrm{Gas}$, and COGAS

- Two-stage, open-circuit cage mill fine crushing - HYGAS and Texaco Partial Oxidation

- Single-stage, closed-circuit cage mill fine crushing All fine coal feed processes except U-Gas and COGAS

- Single-stage cage mill fine crushing with prescreening $\mathrm{U}-\mathrm{Gas}$

- Single-stage, open-circuit rod mill grinding - Texaco Partial Oxidation

Some developers of fine coal consuming conversion processes indicate that ultrafines minimization is important for their conversion reactors. However, none have yet to quantify ultrafines limitations. In anticipation of possible ultrafines removal requirements, an ultrafines separation flow sheet is presented. This flow sheet uses centrifugal type air classifiers to remove minus 100 mesh coal. In order to ensure efficient separation, hot flue gas can be used in the classifiers for coal drying. 
One flow sheet is presented for the H-Coal Process. This flow sheet uses single-stage, open circuit wet ball mills to produce 70 percent minus 200 mesh coal. The grinding fluid is liquefaction solvent; a grinding approach which requires development.

Except for SRC-I, the liquefaction processes involve gasification of liquefaction residual solids. As a result, all conversion processes produce gasification ash or slag. This ash or slag may be discharged as dry solids or a water slurry depending on gasifier design. Solid wastes are also produced by the fluidized-bed steam generators specified for the conversion plant power/steam plant and coal cleaning. Because of limestone injection for sulfur oxides control, solid wastes from the power/steam plant contain calcium sulfate and calcium oxide in addition to coal ash. Quantities of all three types of solid wastes established for conversion of 50,000 tons per day of coal are:

- Granulated slag for conversion processes using slagging gasifiers: 3,912 tons per day

- Ash for conversion processes using nonslagging gasifiers: 5,472 tons per day

- Power/steam plant solid wastes: 984 tons per day

- Coal cleaning refuse: 24,000 tons per day

Two conceptual ash/slag removal flow sheets are presented for handling of the three identified conversion plant solid waste streams. One is for transport of combined solid wastes as a dry material. Methods considered for transport of dry solid wastes are overland conveyors, rail cars, and trucks. The second ash/slag removal flow sheet is for water slurry transport with recycle of water from the solid wastes disposal site. Nominal ash/slag transport distance from conversion plant site to an ultimate, environmentally acceptable disposal site is 5 miles for both ash/slag removal flow sheets. 


\section{Section 3}

\section{CONCLUSIONS}

Conclusions presented in this section apply to the nine specified coal conversion processes and to typical Pittsburgh and Kentucky No. 9 Seam coals. Major conclusions resulting from conceptual coal handling-preparation and ash/slag removal flow sheets and major equipment lists development are:

- In general, equipment which meets the projected coal handling-preparation and ash/slag removal requirements of future commercial coal conversion plants is currently : available. Present capacity limits of some commercially used equipment can probably be overcome by scaleup of existing equipment.

- Improved coal handling-preparation and ash/slag removal equipment is anticipated for future conversion plants due to development of new construction materials, higher equipment reliability requirements, and improved fabrication methods.

- Because of the large investment that will be required for coal conversion plants, substantial investment in high reliability coal handling and preparation facilities would be fully justified.

- Research into the best design approaches for achieving high plant operating reliability in large capacity coal handling and preparation facilities could result in improved coal conversion economics. In this regard evaluation of the performance of existing large capacity material handling/preparation operations, such as power plant coal operations, could provide beneficial reliability information.

- In addition to the best approach(s) to achieving high plant operating reliability, areas where development and demonstration is required.include: 
- Scaleup of coal pulverizers

- Solvent-coal slurry grinding

- Scaleup of gravimetric fecders

- Coal collection baghouse explosion prevention systems

- Pulverized and ultrafine coal transport equipment

- Pressurized ash and slag crushers

- Based on estjmated Pittsburgh and Kentucky No. 9 Seam washability data presented in this report, use of heavy-medium coal cleantng would result in only marginally cleaner coal and/or higher coal recovery than that resulting from the presented conceptual cual leaning flow sheets. However, hoth coal seams cover a wide geographic area and in some locations heavy-medium coal cleaning could be more desirable than other coal cleaning methods. (Consideration of heavy-medium coal cleaning was excluded from project scope.)

- For some codl handling preparation operatinns, economic trade-off sludies are required to determine if they are justified for specific coal conversion plants and, if so, establishment of justified performance requirements. Coal operations, where it is judged that trade-offs would be beneficial, are cleaning, blending, and, for some conversion processes, conversion reactor coal feed size consist requirements.

- Development of data for improved prediction of fine crushing equipment performance would be beneficial for engineering demonstration and commercial coal conversion plants. (Eight: of the nine coal conversion processes require fine coal feed.) A coal fine crushing program similar to that being performed for DOE on coal pulverizing and grinding should be evaluated.

- Removal of inrrafines (1 L his report ultrafina coal is defined as minus 100 mesh coal) trom fine coal befure cuinversion, when required or economically justified, could benefit from development of new or improved large capaclicy fine particulate classification equipment.

- If coal ultrafines removal is used, development of new or improved ultrafines handling and utilization methods could be required.

- The most economic method for obtaining the large quantities of hot gas required for simultaneous coal drying and pulverizing, or for coal fluid bed drying, is from a power/ steam plant steam/gas generator. This approach is more 
efficient than direct coal firing and in the case of fluidizedbed steam/gas generators eliminates the need for flue gas desulfurization following coal pulverizing or drying.

- Conversion reactor ash/slag properties data is limited. Additional data would be beneficial for engineering demonstration and commercial coal conversion plants. 


\section{Section 4}

\section{CONCEPTUAL FLOW SHEETS BASES AND DEVELOPMEITT APPROACH}

\subsection{INTRODUCTION}

Union Carbide Corporation - Nuclear Division, Oak Ridge National Laboratory, is conducting a. survey of coal handling, coal prepartion, and ash/slag removal cquipment requirements fur future, commercial-scale coal conversion plants. This requirements survey is being performed for the Department of Energy (DOE), Fossil Energy. It is part of a major DOE program to establish equipment requirements for large-scale coal conversion plants and to determine the capabilities of manufacturers to provide such equipment:

Major objectives of the Union Carbide survey are determination of : current equipment performance characteristics, suitability of specific equipment for use in commercial coal conversion plants, equipment research and development needs, and lead time requirements for producing and demonstrating equipment of advanced design of critical importance for coàl conversion commercialization.

To efficiently accomplish these objectives, use was made of conceptual flow sheets for the coal and ash/slag operations that will be required by future coal conversion plants. These flow sheets:

- Match the coal feed requirements and ash/slag characteristics of nine conversion processes being considered by DOE for possible demonstration

- Identify equipment performance requirements 
- Demonstrate how individual types of equipment can be integrated to form complete, matched, efficient, reliable materials handling-preparation operations

- Identify areas where equipment deficiencies exist or where improved or new equipment would be beneficial

The commercial-aralc coal conversion plant coal handling-preparation and ash/slag removal conceptual flow sheets were developed for Union Carbide by Bechtel. This report presents the bases established for these flow sheets, the developmental approach used, and the flow sheets. This section covers the first two topics. Section 5 presents the tlow sheets and their associated major equipment lists.

Flow sheets presented in this report represent an extension of a project titled the Coal. Mine-Coal Converision PLart Interface Evaluation and Conceptual Design (1). Th1s project, completed in November 1977, was performed for DOE. The mine-conversion plant interface evaluated consisted of:

- Operations required for mining and transport of coal to a coal conversion plant nominally designed to process 50,000 tons/day of coal and hypothetically sited in the Appalachian region

- All coal operations at the conversion plant preceding actual feeding of coal to a conversion reactor; either liquefaction, high-Btu gasification, or low-Btu gasification

- Ali operations required to collect, treat, transport, and dispose of solid wastes, including conversion reactor ash and/or slag, resulting from coal conversion

Some of the conceptual coal handling-preparation flow sheets developed for the coal mine-coal conversion plant interface project meet some of Union Carbide's flow sheet requirements. These flow sheets have not been reproduced in this report, but are referenced at appropriate points in Section 5 . In addition to flow sheets, the interface project involved development of conceptual plant designs for selected coal operations, estimation of capital costs, and estimation of annual operating costs. 
In developing the flow sheets presented in this report, emphasis was placed on selected coal liquefaction processes specified by Union Carbide. However, because commercial coal liquefaction plants will require gasification operations for hydrogen and/or fuel gas production, coal handling-preparaation and ash/slag removal equipment requirements for selected gasification processes are also included in this report.

\subsection{CONCEPTUAL FLOW SHEETS BASES}

This subsection presents design bases established by Union Carbide and Union Carbide-Bechtel for conceptual flow sheets development. The hases include conversion plants feed coal characteristics, nine coal conversion processes, flow sheets inlet and outlet boundaries, and provision of coal for conversion plant electricity. and process steam generation.

\subsubsection{Conversion Plants Design Feed Coal Characteristics}

Conceptual flow sheets presented in this report are for coal conversion plants that consume 50,000 short tons/day of coal having a nominal total moisture of $8.0 \mathrm{wt}$ percent. To establish annual conversion plant coal consumption, an annual plant operation of 330 days/year was specified. Annual conversion plant coal consumption is, therefore, 16.5 million tons. Conversion plant daily operation was specified as 24 hours.

Two major bituminous coal seams were specified as possible conversion plant coal sources:

- Pittsburgh Seam as represented in Monongalia County, West' Virginia

- Kentucky No. 9 Seam as represented in Hopkins County, - Kentucky

Coal from either seam was postulated to be provided from:

- An integrated coal mine complex located adjacent to the coal conversion plant site 
- A number of separate mines and/or mine complexes spread over the representative and neighboring counties and located an appreciable distance from the conversion plant site

- Both mining alternatives

In the first minlng allernative, the tcrm integrated coal mine complex is used to indicate that such d mining operation would bo extremely large and wnuld probably consist of several mines tied together by a common coal transport system. For the Pittsburgh Seam, such a mine complex would consist exclusively of underground mines. For the Kentucky No. 9 Seam, a significant portion, if not all coal, could probably be produced from surface mines.

In the second mining alternative, the disednces belweeu iuines and the convcroion plant site were pnstulated to be such that coal would be transported to the conversion plant by rall and/or barges. Remote mines would:

- In general, be smaller than a mine that is part of an integrated mine complex located adjacent to a conversion plant site

- In many instances, have shorter lives than the coal conversion plant (Spatial distribution of mines relative to the conversion plant site could change.with conversion plant life.)

- Include both underground and surface mines

Consideration of the teasibility and econumles assuciated with tranoport of 16.5 million tons/year of coal from regional mines in either West Virginia or kentucky to a conversion plant site was not part of the project covered by this report. However, the potential cost of coal transport by railroad and barges to a hypothetical West Virginia site along the Ohio River is discussed in the coal mine-coal conversion plant interface project final report (1). 
Coal produced from an integrated mine complex was specified to have an asreceived size consist of 12 inch $x 0$ and a nominal total moisture of 7:0 wt percent. A coal top size of 12 inches was specified because this is consistent with design requirements for the types of mine transport systems that would be used in an integrated coal mine complex. It is also the nominal. top size of coal typically produced by longwall shearers and continuous miners.

Coal transported to the conversion plant site in rail cars and/or barges was specified to have an as-delivered size consist of 2 inch $x 0$ and a Iunlulal iucal molscure of 8.0 w.t percent. 'l'he 2 inch $x U$ size is that typically used for rail and barge transport in both West Virginia and Kentucky.

\subsubsection{Coal Conversion Plant Coarse Coal Inlet Boundaries}

Two : conversion plant site inlet boundaries were established for initiation of coal handling and preparation flow sheets; one for coal from an adjacent integrated coal mine complex and one for coal transported from remote mines to the conversion plant site. The boundary for coal mined from an integrated mine complex is the discharge point(s) of a surface coal receiving facility. The receiving facility provides surge storage between the mine transport system and the conversion plant conveying system. It would include a silo or large bunker. The discharge point(s) of the conveyor(s) used to convey coal from this silo or bunker constitutes the coal conversion plant inlet boundary. From this boundary, coal (12 inches $x 0$ ) is fed to a breaking facility.

The conversion plant inlet boundary for coal transported by rail and/or barges to the plant site is the discharge point(s) of rail car and/or barge unloading facilities. (Development of flow sheets for any rail and barge unloading facilities was excluded from the project covered by this report.) From this boundary coarse coal (2 inch $\mathrm{x} 0$ ) would normally 
be conveyed to live or dead storage. In the event, however, that oversize or frozen coal is received, it would be conveyed to a crushing facility and then to storage.

\subsubsection{Coal Conversion Processes}

Conceptual flow sheets have been developed which meet the coal handing, preparation, and conversion reactor feeding requirements of nine coal conversion processes. These processes, specified by Union Carbide, and their reported coal feed requirements are presented in Table 4-1. Linformactun presented in this table is conslsteul with each proccoc develuper's. latest coal feed specifications. However, it should be recugnized that all nine conversion processes are developmental. Future process development-demonstration could result in specification of different coal feed requirements and conversion reactor coal feed systems.

Coal feed requirements presented in Table 4-1 are based on design studies using one of the two coals specified in Subsection 4.2.1 or similar bituminous coals. With the exception of $\mathrm{H}$-Coal, the processes do not require coal drying or coal drying is an integral part of the conversion process. To indicate this condition, the term "as received" has been used to identify conversion reactor coal feed moisture requirement. Processes, such as Exxon Donor Solvent (EDS), in which coal drying is part of the conversion leactor syatcm are idantified in the tahie nntes. Astual coal total moisture concentrations considered to be "as received" total moisture range from 7 to $10 \mathrm{WL}$ pereent.

The reactor coal feed size consist presented in Table 4-1 for SRC-1 and -II is only one of several size consists currently being investigated as part of SRC-II demonstration plant engineering. Others include (2):

- Simultaneous coal drying and fine crushing to 100 percent minus 50 mesh to 100 percent minus 20 mesh

- Fine crushing without drying to 100 percent minus 6 mesh to 100 percent minus 12 mesh 
Table 4-1

COAL CONVERSION PROCESSES COAL FEED REQUIREMENTS

\begin{tabular}{|c|c|c|c|c|c|c|c|}
\hline $\begin{array}{c}\text { Process } \\
\text { No. }\end{array}$ & $\begin{array}{l}\text { Conversion } \\
\text { Process } \\
\text { and Type }\end{array}$ & $\begin{array}{l}\text { Conversion Reactor Coal } \\
\text { Feed Size Requirements }\end{array}$ & $\begin{array}{c}\text { Conversion Reactor Coal } \\
\text { Feed Total Moisture } \\
\text { Requirements } \\
\text { Wt Percent }\end{array}$ & $\begin{array}{l}\text { Conversion Reactor } \\
\text { Coal Feed System }\end{array}$ & $\begin{array}{l}\text { Conversion Reactor } \\
\text { Design Operating } \\
\text { Pressure } \\
\text { psig }\end{array}$ & Notes & References ${ }^{(1)}$ \\
\hline 1 & $\begin{array}{l}\text { U-Gas } \\
\text { Fluidized-Bed } \\
\text { Gasification }\end{array}$ & $\begin{array}{l}100 \text { percent minus } 1 / 4 \\
\text { inch } \\
\text { May contain up to } \\
10 \text { percent minus } 200 \\
\text { mesh coal }\end{array}$ & As received & Lock Hopper & $50-350$ & $\begin{array}{l}\text { (1) Cleaned and uncleaned } \\
\text { Kentucky No. } 9 \text { Seam coal } \\
\text { has been successfully } \\
\text { gasified in a pilot gasi- } \\
\text { fier ( } 3 \mathrm{ft} \text { diameter) without } \\
\text { pretreatment to control } \\
\text { agglomeration durlng } \\
\text { gasification. } \\
\text { (2) Pittsburgh Seam coal may } \\
\text { require pretreatment to control } \\
\text { agglomeration during } \\
\text { gasification. }\end{array}$ & 1,2 \\
\hline 2 & $\begin{array}{l}\text { COGAS } \\
\text { Fluidized-Bed } \\
\text { Gasification }\end{array}$ & $\begin{array}{l}100 \text { percent minus } 1 / 8 \\
\text { inch. }\end{array}$ & As received & $\begin{array}{l}\text { Hot Flue Gas } \\
\text { Injection }\end{array}$ & 50 & $\begin{array}{l}\text { (1) The COGAS Process uses mul- } \\
\text { tiple-stage fluidized-bed } \\
\text { pyrolysis. Coal is dried in } \\
\text { the first-stage fluidized-bed } \\
\text { reactor }(\mathrm{s}) \text {. }\end{array}$ & \\
\hline 3 & $\begin{array}{l}\text { HYGAS } \\
\text { Fluidized-Bed } \\
\text { Gasification }\end{array}$ & $\begin{array}{l}100 \text { percent minus } 14 \\
\text { mesh with minimum } \\
\text { minus } 100 \text { mesh }\end{array}$ & As received & $\begin{array}{l}\text { Low-Pressure Lock } \\
\text { Hopper (Feeds Coal } \\
\text { to a Pretreatment } \\
\text { Vessel) }\end{array}$ & $1,155-1,165$ & $\begin{array}{l}\text { (1) Both Pittsburgh Seam and } \\
\text { Kentucky No. } 9 \text { Seam coal were } \\
\text { assumed to require pretreatment } \\
\text { to control agglomeration during } \\
\text { gasification. } \\
\text { (2) Coal is dried during } \\
\text { pretreatment. }\end{array}$ & $1,4,5$ \\
\hline 4 & $\begin{array}{l}\text { Texaco } \\
\text { Partial } \\
\text { Oxidation } \\
\text { Entrained } \\
\text { Flow } \\
\text { Gasification }\end{array}$ & $\begin{array}{l}\text { lno percent minus } 20 \\
\text { mesh with minimum } \\
\text { ultrafines }\end{array}$ & As received & $\begin{array}{l}\text { Water Slurry } \\
\text { Injection from a } \\
\text { slurrying and } \\
\text { Surge Storage } \\
\text { Vessel }\end{array}$ & $500-1,500$ & $\begin{array}{l}\text { (1) Operating temperature and } \\
\text { pressure for the Texaco Par- } \\
\text { tial Oxidation gasifier depends } \\
\text { on synthesis gas requirements } \\
\text { and feed coal composition. }\end{array}$ & 1,6 \\
\hline 5 & $\begin{array}{l}\text { Exxon Donor } \\
\text { Solvent } \\
\text { Liquefaction }\end{array}$ & $\begin{array}{l}100 \text { percent minus } 8 \\
\text { mesh }\end{array}$ & As received & $\begin{array}{l}\text { Donor Solvent } \\
\text { Slurry Injection } \\
\text { from Slurrying and } \\
\text { Drying Vessel }\end{array}$ & 1,485 & $\begin{array}{l}\text { (1) Coal is dried to less than } \\
4 \text { wt percent total moisture } \\
\text { after fine crushing during } \\
\text { slurrying in hot ( } 2750 \mathrm{~F}) \\
\text { recycle donor solvent. }\end{array}$ & 7 \\
\hline 6 & $\begin{array}{l}\text { Exxon } \\
\text { Catalytic } \\
\text { Gasification } \\
\text { Fluidized-Bed } \\
\text { Gasification }\end{array}$ & $\begin{array}{l}100 \text { percent minus } 8 \\
\text { mesh }\end{array}$ & As received & Lock Hopper & 500 & $\begin{array}{l}\text { (1) Coal is dried after fine } \\
\text { crushing and catalyst addition. } \\
\text { Catalyst is added as an aqueous } \\
\text { solution. }\end{array}$ & 8 \\
\hline
\end{tabular}

(1) Presented in Report References section 
THIS PAGE

\section{WAS INTENTIONALLY LEFT BLANK}




\begin{tabular}{|c|c|c|c|c|c|c|c|}
\hline $\begin{array}{l}\text { Process } \\
\text { No. }\end{array}$ & $\begin{array}{l}\text { Conversion } \\
\text { Process } \\
\text { and Type }\end{array}$ & $\begin{array}{l}\text { Conversion Reactor Coal } \\
\text { Feed Stze Requirements }\end{array}$ & $\begin{array}{c}\text { Conversion Reactor Coal } \\
\text { Feed Total Molsture } \\
\text { Requirements } \\
\text { Wt Percent }\end{array}$ & $\begin{array}{l}\text { Conversion Reactor } \\
\text { Coal Feed System }\end{array}$ & $\begin{array}{c}\text { Conversion Reactor } \\
\text { Design Operating } \\
\text { Pressure } \\
\text { psig }\end{array}$ & Notes & References $(1)$ \\
\hline 7 and 8 & $\begin{array}{l}\text { SRC-I and } \\
\text { SRC-II } \\
\text { Liquef action } \\
\\
\\
\text { H-Coal } \\
\text { Liquefaction }\end{array}$ & $\begin{array}{l}100 \text { percent minus } 12 \\
\text { mesh } \\
100 \text { percent minus } 40 \\
\text { mesh } \\
70 \text { percent minus } 200 \\
\text { mesh }\end{array}$ & $\begin{array}{l}\text { As received } \\
2 \text { wt percent }\end{array}$ & $\begin{array}{l}\text { Solvent Slurry } \\
\text { Injection from a } \\
\text { Slurrying and } \\
\text { Drying Vessel } \\
\\
\text { Solvent Slurry } \\
\text { Injection from a } \\
\text { Slurrying Vessel }\end{array}$ & $\begin{array}{r}2,400 \\
2,700\end{array}$ & $\begin{array}{l}\text { (1) Gulf Mineral Resource Co. } \\
\text { is currently evaluating a } \\
\text { range of conversion reactor } \\
\text { coal feed size consists for } \\
\text { SRC-I and II demonstration } \\
\text { plants. These range from } \\
100 \text { percent minus } 6 \text { mesh to } \\
100 \text { percent minus } 50 \text { mesh. } \\
\text { (2) In some commercial-scale } \\
\text { conceptual conversion plant } \\
\text { designs, pulverized coal } \\
\text { (nominally } 70 \text { percent minus } \\
\text { 200 mesh) has been specified } \\
\text { for the SRC-II process. } \\
\text { (3) Coal is dried after fine } \\
\text { crushing during slurrying in } \\
\text { hot recycle solvent. } \\
\text { (1) Coal is dried during } \\
\text { pulverizing. }\end{array}$ & 10 \\
\hline \multicolumn{8}{|c|}{ Presented in Report References section } \\
\hline
\end{tabular}




\section{THIS PAGE}

\section{WAS INTENTIONALLY LEFT BLANK}


For gasification of Pittsburgh Seam, Kentucky No. 9 Seam, and similar coals by the HYGAS process, a pretreatment operation is required. This pretreatment produces a nonagglomerating char which is then fed to the multistage HYGAS gasifier. In the pretreatment operation, coal is contacted with air in a fluidized bed at $750-850^{\circ} \mathrm{F}$. This results in coal oxidation which greatly reduces its tendency to agglomerate at the temperatures used for gasification. Gasification of Pittsburgh Seam coal by the U-Gas process may also require pretreatment similar to that required for HYGAS.

Conversion reactor pressures presented in Table 4-1 are order-of-magnitude values. They are provided only to indicate the pressurization that must be achieved by conversion reactor coal feed systems. Actual conversion reactor operating pressures depend on the coal being converted, reactor product requirements, and other conditions.

Table 4-2 presents design information used to establish ash/slag removal flow sheets starting (inlet) boundaries and ash/slag characteristics for the nine coal conversion processes. In the Exxon Donor Solvent, SRC-II, and H-Coal liquefaction processes some form of fractionation is used to recover gas and liquid products from the slurry resulting from coal liquefaction. An additional product of liquefied coal fractionation is a high boiling point slurry frequently referred to as bottoms. This slurry (the solid phase consists of coal mineral matter products and undissolved organics) is gasified to produce synthesis gas which is used for hydrogen production and in-plant fuel gas. The EDS process also recovers additional gas and liquid products from fractionation bottoms using Exxon Flexicoking technology (3). In Table 4-2 the gasifier designs identified for the EDS, SRC-II, and H-Coal processes are those believed to be currently favored by the respective process developers, for fractionation bottoms gasification. Different gasifiers. could, however, be used with these processes.

In the SRC-I process, a low-ash solid fuel is produced by removal of solids from liquefied coal. The separated solids may or may not be suitable for

\section{Preceding page blank $4-11$}


THIS PAGE

WAS INTENTIONALLY

LEFT BLANK 


\begin{tabular}{|c|c|c|c|c|c|c|c|}
\hline $\begin{array}{l}\text { Process } \\
\text { No. }\end{array}$ & Conversion Process & $\begin{array}{l}\text { Gasifier } \\
\text { Design (1) }\end{array}$ & $\begin{array}{c}\text { Gasifier } \\
\text { Design Operating } \\
\text { Temperature } \\
{ }^{\circ} \mathrm{F}\end{array}$ & $\begin{array}{l}\text { Gasifier Ash or Slag } \\
\text { Removal Method }\end{array}$ & $\begin{array}{c}\text { Ash or Slag } \\
\text { Characteristics }\end{array}$ & Notes & References ${ }^{(2)}$ \\
\hline 1 & U-Gas & 更 & $\begin{array}{c}1,800-2,000 \\
\vdots \\
\vdots \\
\vdots\end{array}$ & $\begin{array}{l}\text { The U-Gas gasifier is } \\
\text { designed to agglomerate } \\
\text { fine ash particles in a } \\
\text { specially designed } \\
\text { spout or spouts located } \\
\text { at the bottom of the } \\
\text { gasifier fludized bed. } \\
\text { When ash particles grow } \\
\text { to sufficient mass they } \\
\text { deentrain from the } \\
\text { fluidized bed and fall } \\
\text { into a water-filled } \\
\text { lock hopper located at } \\
\text { the gasifier bottom. } \\
\text { Agglomerated ash-water } \\
\text { slurry is periodically } \\
\text { discharged from the ash } \\
\text { lock hopper. }\end{array}$ & $\begin{array}{l}\text { Reported mean particle } \\
\text { sizes for agglomerated } \\
\text { ash range from } 6 \text { to } \\
14 \text { mesh } \\
\text { Ash agglomerates contain } \\
5-10 \text { wt percent carbon }\end{array}$ & $\begin{array}{l}\text { (1) Gasifier operating } \\
\text { temperature is dependent } \\
\text { on coal ash fusion tem- } \\
\text { perature characteristics. } \\
\text { Steam and oxygen fed to } \\
\text { the gasifier ash agglom- } \\
\text { erating spout (s) located } \\
\text { at the bottom of the } \\
\text { fluidized bed are con- } \\
\text { trolled to maintain ash } \\
\text { particles near their } \\
\text { softening temperature. } \\
\text { (2) Agglomerated ash } \\
\text { size consist depends on } \\
\text { feed coal size consist, } \\
\text { gasifier temperature, } \\
\text { and agglomerating spout } \\
\text { configuration. }\end{array}$ & $1,2,11$ \\
\hline 2 & COGAS & $\begin{array}{l}\text { Fluidized Bed } \\
\text { and a Cyclone } \\
\text { Char Combustor }\end{array}$ & $1,600-1,700$ & $\begin{array}{l}\text { Char from multiple- } \\
\text { stage coal pyrolysis is } \\
\text { gasified with steam in } \\
\text { a fluidized bed. Heat } \\
\text { for char gasification } \\
\text { is obtained by burning } \\
\text { char fines in a ver- } \\
\text { tical, cyclone, slag- } \\
\text { ging combustor operat- } \\
\text { Ing at moderate pres- } \\
\text { sure. Molten slag from } \\
\text { the combustor flows to } \\
\text { a water-filled vessel } \\
\text { located below the com- } \\
\text { bustor where it is } \\
\text { quenched and granu- } \\
\text { lated. Granulated } \\
\text { slag-water slurry is } \\
\text { periodically discharged } \\
\text { from the quench vessel } \\
\text { by means of a valve } \\
\text { system. }\end{array}$ & $\begin{array}{l}\text { Granulated slag con- } \\
\text { tains less than } 0.5 \text { wt } \\
\text { percent carbon. }\end{array}$ & $\begin{array}{l}\text { (1) Operation of cyclone } \\
\text { combustors is dependent } \\
\text { upon slag viscosity which } \\
\text { is dependent on coal ash } \\
\text { composition. Fluxing } \\
\text { compounds could be re- } \\
\text { quired to control slag } \\
\text { viscosity of char pro- } \\
\text { duced by pyrolysis of } \\
\text { some coals. }\end{array}$ & $1,3,12$ \\
\hline
\end{tabular}


THIS PAGE

WAS INTENTIONALLY

LEFT BLANK 


\begin{tabular}{|c|c|c|c|c|c|c|c|}
\hline $\begin{array}{l}\text { Process } \\
\text { No. }\end{array}$ & Conversion Process & $\begin{array}{c}\text { Gasifier } \\
\text { Design (1) }\end{array}$ & $\begin{array}{c}\text { Gasifier } \\
\text { Design Operating } \\
\text { Temperature } \\
\text { OF }\end{array}$ & $\begin{array}{l}\text { Gasifier Ash or Slag } \\
\text { Removal Method }\end{array}$ & $\begin{array}{c}\text { Ash or Slag } \\
\text { Characteristics }\end{array}$ & Notes & References (2) \\
\hline 3 & HYGAS & $\begin{array}{l}\text { Vertical } \\
\text { Multi-stage } \\
\text { Fluidized Bed } \\
\end{array}$ & $\begin{array}{l}1,500-1,800 \\
\text { (Steam-0xygen } \\
\text { Gastfication } \\
\text { Stage) }\end{array}$ & $\begin{array}{l}\text { The HYGAS gasifier pro- } \\
\text { duces a high ash char } \\
\text { which can be burned for } \\
\text { steam generation and/or } \\
\text { disposed of as solid } \\
\text { waste. Char removed } \\
\text { from the steam-oxygen } \\
\text { gasification stage is } \\
\text { water-quenched in the } \\
\text { gasifier bottom. Char- } \\
\text { water slurry is period- } \\
\text { ically discharged from } \\
\text { the gasifier by means } \\
\text { of a water-filled lock } \\
\text { hopper system. }\end{array}$ & $\begin{array}{l}\text { Reported char ash con- } \\
\text { centration is on the } \\
\text { order of } 65 \text { wt percent } \\
\text { Reported char higher } \\
\text { heat value is on the } \\
\text { order of } 5,400 \text { Btu } / 1 \text {, } \\
\text { dry basis. }\end{array}$ & $\begin{array}{l}\text { (1) The HYGAS gasifier } \\
\text { is non-slagging. As a } \\
\text { result coal and char } \\
\text { ash fusion temperatures } \\
\text { must be sufficiently } \\
\text { high to prevent slagging } \\
\text { or sintering during } \\
\text { hydrogasification and } \\
\text { steam-oxygen } \\
\text { gasification. }\end{array}$ & $1,4,5,13$ \\
\hline 4 & Texaco Partial Oxidation & $\begin{array}{l}\text { Slagging } \\
\text { Entrained } \\
\text { Downflow }\end{array}$ & $2,000-2,800$ & $\begin{array}{l}\text { At the temperatures } \\
\text { used in this oxygen- } \\
\text { blown gasifier most } \\
\text { coal ash is converted } \\
\text { to slag. Most of this } \\
\text { slag is captured, } \\
\text { quenched, and granu- } \\
\text { lated in the water- } \\
\text { filled bottom of the } \\
\text { gasifier, Granulated } \\
\text { slag passes to a water- } \\
\text { filled lock hopper sys- } \\
\text { tem located below the } \\
\text { gasifier. Granulated } \\
\text { slag-water slurly is } \\
\text { perlodically dlscharged } \\
\text { from the lock hopper } \\
\text { system. }\end{array}$ & $\begin{array}{l}\text { Granulated slag size } \\
\text { consist is coal } \\
\text { dependent } \\
\text { slag carbon concentra- } \\
\text { tion is } 2 \text { wt percent } \\
\text { or less }\end{array}$ & $\begin{array}{l}\text { (1) The Texaco Partial } \\
\text { Oxidation gasifier oper- } \\
\text { ates at a temperature } \\
\text { approximately 50F above } \\
\text { coal feed ash fusion } \\
\text { temperature. Coals with } \\
\text { high ash fusion tempera- } \\
\text { tures require more oxy- } \\
\text { gen than coals having } \\
\text { lower ash fusion } \\
\text { temperatures. }\end{array}$ & 1,6 \\
\hline
\end{tabular}




\section{THIS PAGE}

\section{WAS INTENTIONALLY LEFT BLANK}




\begin{tabular}{|c|c|c|c|c|c|c|c|}
\hline $\begin{array}{c}\text { Process } \\
\text { No. }\end{array}$ & Conversion Process & $\begin{array}{l}\text { Gasifier } \\
\text { Design }(1)\end{array}$ & $\begin{array}{c}\text { Gasifier } \\
\text { Design Operating } \\
\text { Temperature } \\
\text { OF }_{F}\end{array}$ & $\begin{array}{l}\text { Gastfier Ash or Slag } \\
\text { Removal Method }\end{array}$ & $\begin{array}{c}\text { Ash or Slag } \\
\text { Characteristics }\end{array}$ & Notes & References ${ }^{(2)}$ \\
\hline 5 & Exxon Donor Solvent & $\begin{array}{l}\text { Fluidized Bed } \\
\text {. }\end{array}$ & 更 & $\begin{array}{l}\text { Three types of coke re- } \\
\text { sult from the EDS } \\
\text { Flexicoking approach to } \\
\text { treatment of liquefaca- } \\
\text { tion process fraction- } \\
\text { ation bottoms : dry } \\
\text { coke fines, coke } \\
\text { slurry, coke chunks- } \\
\text { agglomerates. Dry coke } \\
\text { fines are removed by } \\
\text { eyclones from the low- } \\
\text { Btu fuel gas resulting } \\
\text { from coke gasification. } \\
\text { Coke slurry results } \\
\text { from water scrubbing of } \\
\text { the low-Btu gas result- } \\
\text { ing from coke gasifica- } \\
\text { tion.. Coke chunks and } \\
\text { agglomerates are peri- } \\
\text { odically removed from } \\
\text { the gasifier bed. }\end{array}$ & $\begin{array}{l}\text { Estimated total coke ash } \\
\text { is } 66 \text { wt percent. } \\
\text { Dry Coke Fines: Bulk } \\
\text { Density, } 25 \text { Ibs/ft } 3 \\
\text { Size Consist, } 100 \text { per- } \\
\text { cent minus } 20 \text { microns } \\
\text { Coke Slurry: } 60 \text { wt per- } \\
\text { cent moisture after } \\
\text { vacuum filtration } \\
\text { Chunk Coke: Bulk Den- } \\
\text { sity, G5 Ils /IL } 3 \\
\text { Size Consist, } 1 / 4-1 \\
\text { inch mean size }\end{array}$ & $\begin{array}{l}\text { (1) Several approaches } \\
\text { for treatment of frac- } \\
\text { tionation bottoms are } \\
\text { being evaluated for } \\
\text { the EDS Process. Other } \\
\text { coke gasification } \\
\text { processes include } \\
\text { Texaco Partial Oxida- } \\
\text { tion Gasification. }\end{array}$ & 7 \\
\hline 6 & $\begin{array}{l}\text { Exxon Catalytic } \\
\text { Gasification }\end{array}$ & 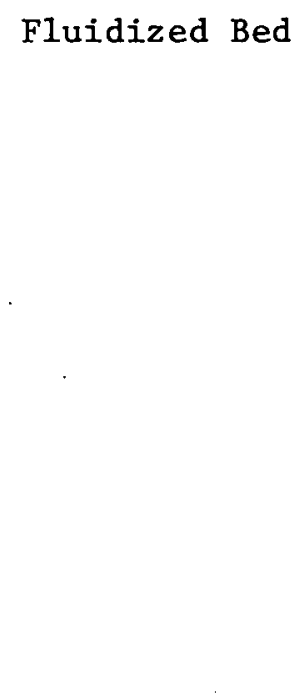 & 更 & $\begin{array}{l}\text { Char resulting from } \\
\text { gasification is water } \\
\text { quenched at gasifica- } \\
\text { tion pressure and fed } \\
\text { to a digester using a } \\
\text { lock hopper system. } \\
\text { Char is digested at ap- } \\
\text { proximately } 300^{\circ} \text { F with } \\
\text { Ca(OH) } 2 \text {. After diges- } \\
\text { tion, the char slurry } \\
\text { is washed countercur- } \\
\text { rently with water in } \\
\text { multiple vessels. } \\
\text { Vacuum filtration would } \\
\text { likely be used for } \\
\text { final char dewatering. }\end{array}$ & Not Available & $\begin{array}{l}\text { (1) This is a relatively } \\
\text { new gasification process } \\
\text { and has not been devel- } \\
\text { oped to the same extent } \\
\text { as the other gasifica- } \\
\text { tion processes consid- } \\
\text { ered in this table. }\end{array}$ & 8,14 \\
\hline $\begin{array}{c}7 \\
\text { and } \\
8\end{array}$ & SRC-I and SRC-II & $\begin{array}{l}\text { Slagging } \\
\text { Entrained } \\
\text { Down Flow }\end{array}$ & $2,000-2,800$ & $\begin{array}{l}\text { For development of con- } \\
\text { ceptual ash/slag re- } \\
\text { moval flow sheets } \\
\text { SRC-II fractionation } \\
\text { bottoms are assumed } \\
\text { gasified using the } \\
\text { Texaco Partial Oxida- } \\
\text { tion (Process No. 4). } \\
\text { SRC-I solids are } \\
\text { removed from liquified } \\
\text { coal by filtration. }\end{array}$ & See Process No. 4 & $\begin{array}{l}\text { (1) For SRC-I Texaco } \\
\text { Partial Oxidation gasi- } \\
\text { fication of coal was } \\
\text { assumed to be used for } \\
\text { hydrogen production. }\end{array}$ & - \\
\hline
\end{tabular}


THIS PAGE

\section{WAS INTENTIONALLY LEFT BLANK}


Tab1e 4-2 (Continued)

\begin{tabular}{|c|c|c|c|c|c|c|c|}
\hline $\begin{array}{l}\text { Process } \\
\text { No. }\end{array}$ & Conversion Process & $\begin{array}{c}\text { Gasifier } \\
\text { Design (1) }\end{array}$ & $\begin{array}{c}\text { Gastfier } \\
\text { Design Operating } \\
\text { Temperature } \\
\mathrm{O}_{F}\end{array}$ & $\begin{array}{l}\text { Gasifier Ash or Slag } \\
\text { Removal Method }\end{array}$ & $\begin{array}{l}\text { Ash or Slag } \\
\text { Characteristics }\end{array}$ & Notes & References ${ }^{(2)}$ \\
\hline 9 & H-Coal & $\begin{array}{l}\text { Slagging } \\
\text { Entrained } \\
\text { Down Flow }\end{array}$ & $2,000-2,800$ & $\begin{array}{l}\text { For development of con- } \\
\text { ceptual ash/slag } \\
\text { removal flow sheets } \\
\text { fractionation bottoms } \\
\text { from the H-Coal Process } \\
\text { are assumed gasifled } \\
\text { using the Texaco Par- } \\
\text { tial Oxidation Process } \\
\text { (see Process No. 4). }\end{array}$ & See Process No. 4 & 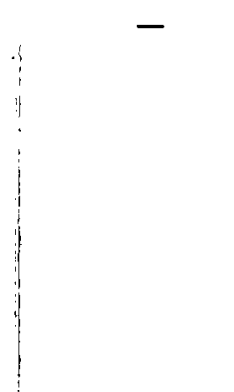 & - \\
\hline
\end{tabular}

(1) All liquefaction conversion processes except SRC-I considered in this table gasify solids resulting from coal liquefaction and subsequent liquefied coal fractionation. For these processes, this column identifies the type of gasifier currently being considered for such gasification.

(2) Presented in Report References section 
THIS PAGE

WAS INTENTIONALLY LEFT BLANK 
gasification. Therefore, for ash/slag removal flow sheets development, these solids were specified to be disposed of without gasification. Hydrogen for SRC-I coal liquefaction was specified as being produced from coal gasification. The Texaco Partial Oxidation Gasifier is considered a likely gasifier for this purpose.

Gasifier design operating temperatures presented in Table 4-2 are approximate values. Actual operating temperatures would be determined by both feed coal properties, particularly ash fusion-slagging characteristics and synthesis gas requirements. This is specially true for the liquefaction processes. Much remains to be learned about gasification of fractionation bottoms and other slurries that might result from liquefaction processes.

Two basic types of gasifiers are identified in Table 4-2; slagging (COGAS combustor and Texaco Partial Oxidation) and non-slagging (U-Gas, HYGAS, EDS, and Exxon Catalytic Gasification). Operation of both types are affected by ash fusion or slagging characteristics. Obviously, in the case of liquefied coal fractionation bottoms gasiffcation, other factors will affect gasifier operation, but conversion reactor feed coal mineral matter composition is probably the most significant. In the notes portion of Table 4-2 an attempt is made to qualify coal ash fusion characteristics effects. However, detailed consideration of the effect of coal ash fusion characteristics on gasifier operation is outside the scope of this report.

In addition to the information presented in Table 4-2 concerning gasification and feed ash fusion-slagging characteristics, a brief survey was made of reported ash fusion temperatures for both Pittsburgh and Kentucky No. 9 coals. Typical ash compositions and fusion temperatures for these coals are presented in Table 4-3. Figure 4-1, taken from a U.S. Bureau of Mines Report of Investigations (4), presents the predicted large-scale variability of ash softening temperature for the Pittsburgh Seam in northern West Virginia (including Monongalia County), western Pennsylvania, and 
Table 4-3

SELECTED COAL ASH ANALYSIS AND

FUSION TEMPERATURES

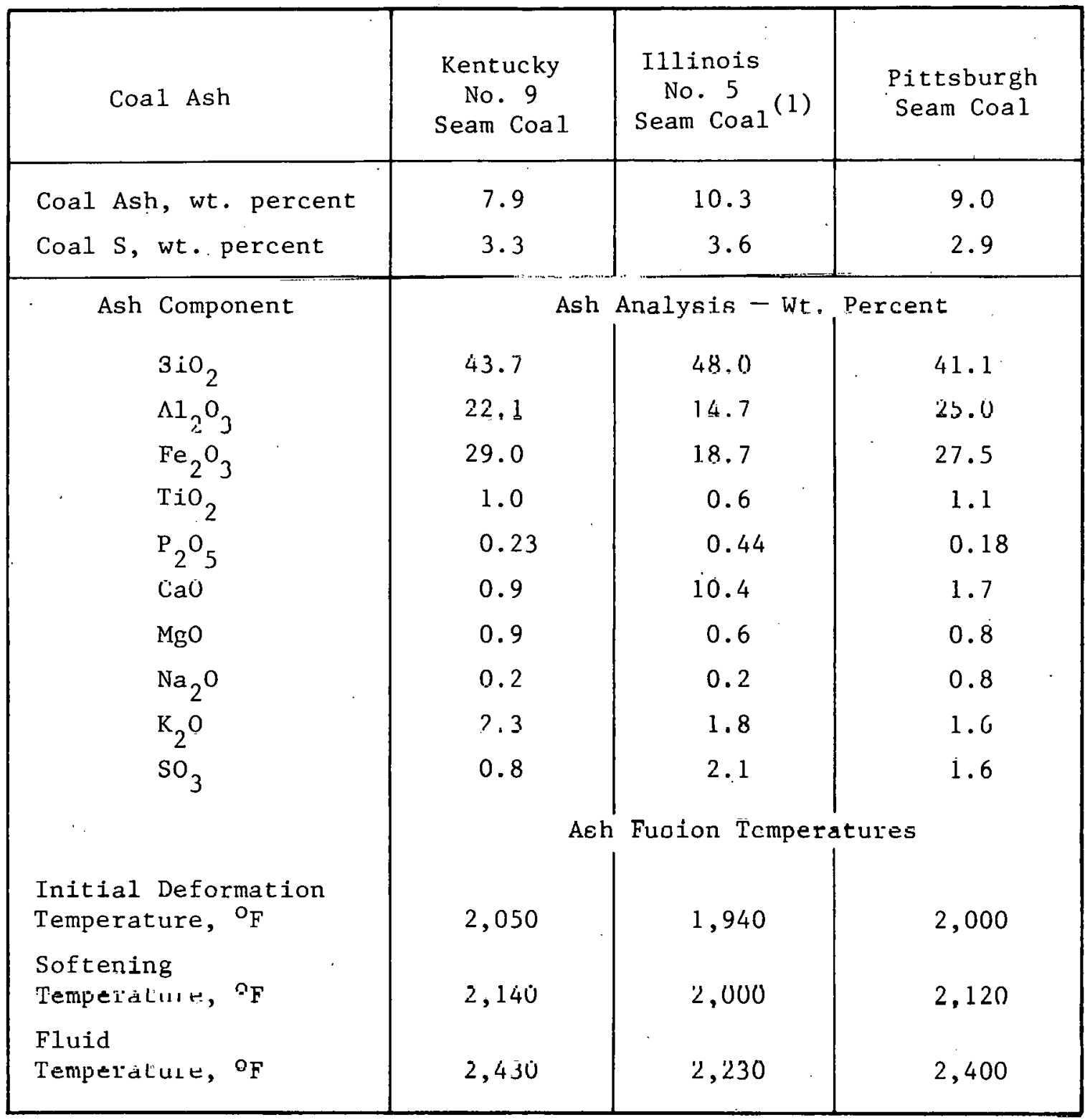

Notes:

(1) Illinois No. 5 and Kentucky No. 9 are the same coal seam.

(2) Data taken from Reference (5). 


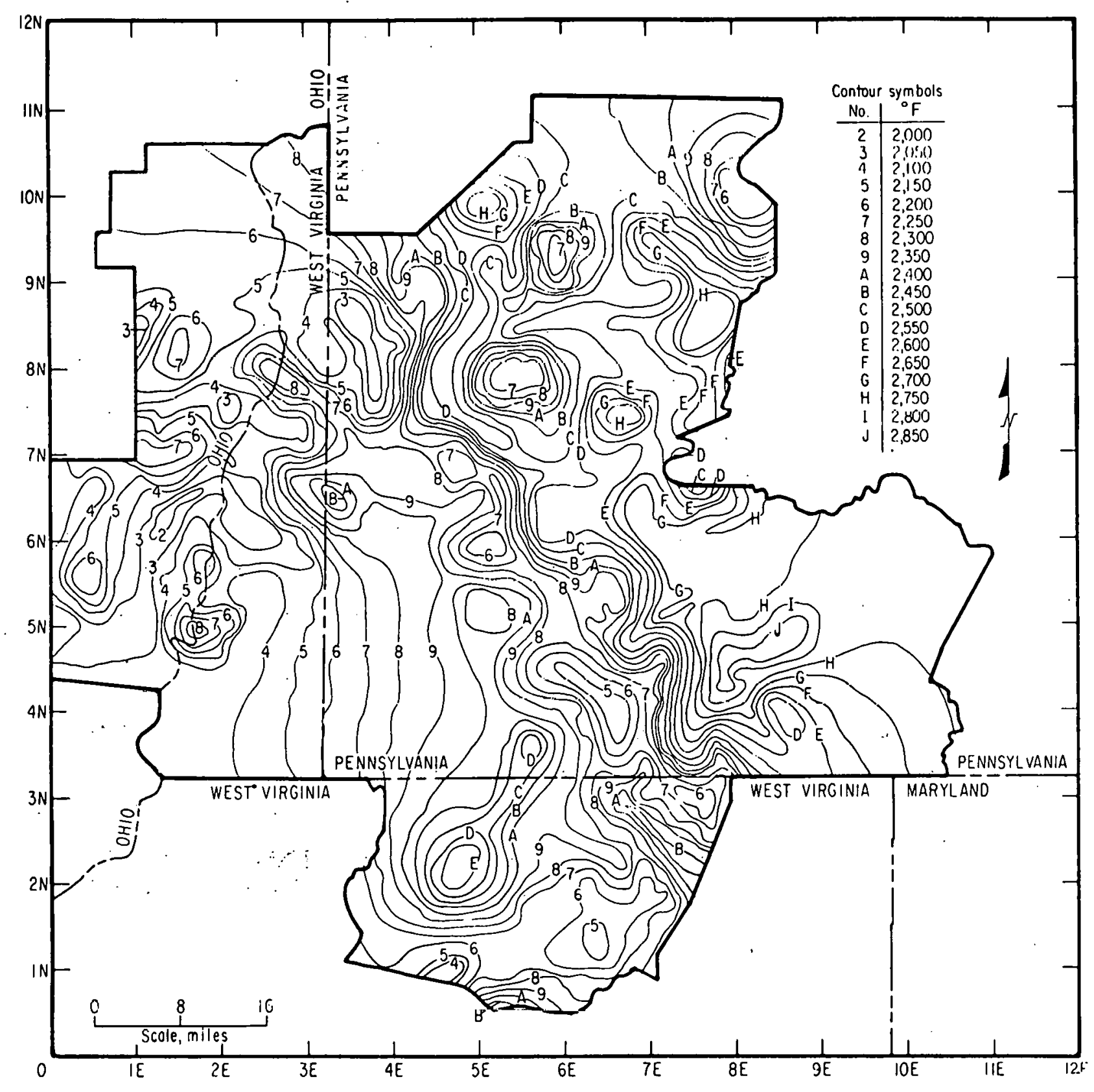

Figure 4-1 FORECAST OF ASH-SOFTENING TEMPERATURES OF PITTSBURGH SEAM COAL(4) 
eastern Ohio. The Figure 4-1 forecast is based on 50 independent mine samples. The ash softening temperatures of these samples ranged from $1,960^{\circ} \mathrm{F}$ to $2,940^{\circ} \mathrm{F}$. Mean softening temperature for the 50 samples was $2,378^{\circ} \mathrm{F}$ and their standard deviation was $271 \mathrm{~F}^{\circ}$. No large-seale investigation of ash fusion temperatures, such as that used to develop Figure 4-1, was located for Kentucky No. 9 Seam coal.

Comparison of the Table 4-3 ash fusion temperatures with the approximate gasifier design operating temperatures presented in Table 4-2 indicates that both coals appear to be compatible with the specified gasifiere. Data for fixed-bed slagging gasification of Pittsburgh Seam coal $(6,7)$ indicates that the viscosity-temperature characteristics of the slag are acceptable for the COGAS char cyclone combustor. Inasmuch as Kentucky No. 9 Seam coal is successfully fired in cyclone utility steam generators, this coal also appears to be suitable for the COGAS combustor. (Note: the design operating temperature shown for COGAS in Table 4-2 is for the fluidized-. bed gasifier, not the char combustor.)

Coal ash fusion temperatures and slagging characteristics, being dependent on ash composition, are affected by coal cleaning. Table 4-4 indicates how ash fusion temperatures can change as a function of degree of cleaning. In general, cleaning appears to increase the ash fusion temperatures of Eastern bituminous coal. (Coal cleaning is discussed further in subsection 4.2 .5$.

\subsubsection{Coal Conversion Processes Coal and Ash/Slag :Handling Boundaries}

Table 4-1 identifies three basic methods for feeding coal to a pressurized coal conversion reactor or pretreater: lock hopper system, gas injection, and slurry injection. Outlet coal boundaries (the points at which the coal handling-preparation conceptual flow sheets terminate) established for each of these basic methods are as follows: 
Table 4-4

TYPICAL ILLINOIS NO. 5 COAL ASH FUSION TEMPERATURES REDUCING ATMOSPHERE(1)

\begin{tabular}{|c|c|c|c|c|c|c|c|c|c|c|c|}
\hline \multicolumn{3}{|c|}{$\left.\begin{array}{c}\text { Initial } \\
\text { Temperature }\end{array}{ }^{\circ} \mathrm{F}\right)$} & \multicolumn{3}{c|}{ Softening } & \multicolumn{3}{c|}{$\begin{array}{c}\text { Hemispherical } \\
\text { Temperature }\end{array}$} & \multicolumn{3}{c|}{ Fluid } \\
\hline LGF $^{(2)}$ & IGF $^{(3)}$ & HGF $^{(4)}$ & LGF & IGF & HGF & LGF & IGF & HGF & LGF & IGF & HGF \\
\hline 1,890 & 1,910 & 1,900 & 2,150 & 2,160 & 2,080 & 2,170 & 2,170 & 2,100 & 2,485 & 2,430 & 2,280 \\
2,020 & 2,020 & 1,970 & 2,230 & 2,230 & 2,090 & 2,260 & 2,260 & 2,115 & 2,560 & 2,570 & 2,260 \\
1,950 & 2,030 & 1,960 & 2,290 & 2,240 & 2,100 & 2,320 & 2,260 & 2,130 & 2,520 & 2,600 & 2,350 \\
2,000 & 2,010 & 1,970 & 2,150 & 2,160 & 2,100 & 2,200 & 2,200 & 2,150 & 2,320 & 2,350 & 2,310 \\
1,960 & 1,940 & 1,880 & 2,040 & 2,050 & 1,960 & 2,130 & 2,125 & 2,000 & 2,300 & 2,400 & 2,100 \\
2,060 & 2,050 & 1,980 & 2,480 & 2,370 & 2,265 & 2,500 & 2,405 & 2,280 & 2,620 & 2,610 & 2,480 \\
1,850 & 2,320 & 1,850 & 2,500 & 2,520 & 2,310 & 2,530 & 2,540 & 2,340 & 2,680 & 2,650 & 2,600 \\
1,915 & 1,900 & 1,975 & 2,135 & 2,150 & 2,110 & 2,155 & 2,180 & 2,140 & 2,410 & 2,425 & 2,360 \\
\hline 1,955 & 2,022 & 1,936 & 2,246 & 2,235 & 2,126 & 2,283 & 2,267 & 2,156 & 2,500 & 2,504 & 2,342 \\
\hline
\end{tabular}

Notes:

(1) Data are for $1 \frac{1}{2}$ inch - 0 size range. Illinois-No. 5 and Kentucky No. 9 are the same coal seam.

(2) LGF - lowest gravity float fraction (1.23 to 1.31 sperific gravity).

(3) IGF - intermediate gravity float fraction ( 1.26 to 1.355 specific gravity).

(4) HGF - highest gravity float fraction ( 1.60 specific gravity).

Reference:

Sulfur Reduction of Illinois - Coals Washability Studies, Part I, R.J. Helfinstine, N.F. Shimp, J.A. Simon, and M.E. Hopkins, State of Illinois, Circular 462 (1971). 
- Lock Hopper Coal Feed Systems - The coal inlet of the vessel or vessels used to provide crushed coal surge storage for the lock hoppers (Any particulate or other emission control systems associated with the lock hopper receiving vessels are not considered part of coal handling-preparation.)

- Gas Injection Coal Feed Systems (COGAS Process On1y) - The coal inlet of the vessel or vessels used to feed the first stage, fluidized-bed pyrolyzer(s)

- Slurry Injection Coal Feed Systems - The coal inlet of the slurry preparation vessel or vessels used for slurrying coal in recycle solvent or water (Any slurry preparation vessel off-gas treatment and agitation systems are not considered part of coal handling-preparation.)

As discussed in the previous subsection, pretreatment to control agglomeration is believed to be required for HYGAS. As a result, the coal outlet boundary for this process was specified to be the pretreatment coal feed system, not the gasifier coal feed system. When pretreatment is used with HYGAS, the resulting pretreatment char is slurried in a process-derived oil and injected into the gasifier.

Except for the EDS process, ash, char, or slag produced by the gasifiers identified in Table 4-2 is quenched in water at gasifier operating pressure and then periodically removed through a lock hopper or simflar mechanical depressuiting system. In these removal systems, steam generated by quenching flows back into the gasifier where it reacts or exits as part of the gasifier gases. The ash or slag quench-removal systems identified in Table 4-2 form an integral part of the gasifiers. Mo a rcoult, foil Llest processes, the ash or slag removal flow sheets inlet boundary was specifled to be at the point or points where quenched ash or slag is periodically discharged from a lock hopper or similar pressure letdown eyotcm.

Most of the ash produced by the EDS process fluidized-bed gasifier leaves entrained in the synthesis gas. This gas flows through a coke heater and then to a waste heat boiler. After heat recovery, ash particulates arc 
removed from the synthesis gas in two stages. First, coarse particles are removed in a dry collection system. The coarse collected dry ash is cooled in an indirect solids cooler and then preumatically conveyed to a transfer point for transport to disposal. In the second ash removal stage, wet scrubbing is used to remove fine ash particulates. Slurry resulting from synthesis gas scrubbing is dewatered on a vacuum filter.

Ash inlet boundaries for the EDS process ash removal flow sheets were specified to be at the discharge of the dry ash pneumatic transport system and at the slurry discharge of the wet synthesis gas scrubbing system. A limited amount of coke chunks are periodically removed from the EDS gasifier. These chunks were assumed to be combined with dry ash for transport to disposal.

\subsubsection{Coal Cleaning}

Development of conceptual coal handling-preparation flow sheets which include conventional, physical coal cleaning was a project requirement specified by Union Carbide. However, to avoid duplication of work being performed by other DOE contractors, heavy-medium coal cleaning was excluded from the cleaning processes to be considered for flow sheet development.

In order to develop coal, cleaning flow sheets, typical coal washability data were developed for both Pittsburgh and Kentucky No. 9 coals. These data are presented in Tables 4-5 through 4-8 and are plotted in Figures 4-2 through 4-5. Tables 4-5 and 4-7 represent analysis of channel coal samples. These samples were taken from an actual mine in a manner that avoids their contamination with extraneous mine roof and floor material. In actual mining, some roof and floor material is unavoidably or purposely taken with the cual. In certain areas of the Pittshurgh Seam, for example, as much as 18 inches of roof draw slate is mined in order to obtain adequate roof support. 
Table 4-5

PITTSBURGH SEAM COAL

WASHABILITY CHARACTERISTICS WITHOUT ROOF AND FLOOR DILUTION

\begin{tabular}{|c|c|c|c|c|c|c|c|c|c|c|}
\hline \multirow[b]{3}{*}{$\begin{array}{l}\text { Specific } \\
\text { Gravity }\end{array}$} & \multicolumn{5}{|c|}{ Elementary Data } & \multicolumn{5}{|c|}{ Cumulative Data } \\
\hline & \multirow[b]{2}{*}{$\begin{array}{l}\text { Weight } \\
\text { Percent }\end{array}$} & \multirow[b]{2}{*}{$\begin{array}{c}\text { Ash } \\
\text { Percent }\end{array}$} & \multicolumn{2}{|c|}{ Sulfur } & \multirow[b]{2}{*}{$\begin{array}{c}\mathrm{HHV} \\
\mathrm{Btu} / 1 \mathrm{~b}\end{array}$} & \multirow[b]{2}{*}{$\begin{array}{l}\text { Weight } \\
\text { Percent }\end{array}$} & \multirow[b]{2}{*}{$\begin{array}{c}\text { Ash } \\
\text { Percent }\end{array}$} & \multicolumn{2}{|c|}{ Sulfur } & \multirow[b]{2}{*}{$\begin{array}{c}\text { HHV } \\
\text { Btu/1b }\end{array}$} \\
\hline & & & $\begin{array}{l}\text { Pyrittc } \\
\text { Percent }\end{array}$ & $\begin{array}{c}\text { Total } \\
\text { Percent }\end{array}$ & & & & $\begin{array}{l}\text { Pyritic } \\
\text { Percent }\end{array}$ & $\begin{array}{c}\text { Total } \\
\text { Percent }\end{array}$ & \\
\hline & & & & .5 inch & $38 \mathrm{~mm}) \mathrm{x}$ & 00 mesh & & & & \\
\hline $\begin{aligned}-1.30 \\
1.30-1.40 \\
1.40-1.60 \\
+1.60\end{aligned}$ & $\begin{array}{r}57.85 \\
32.08 \\
6.07 \\
4.00\end{array}$ & $\begin{array}{r}4.83 \\
10.02 \\
19.65 \\
53.75\end{array}$ & $\begin{array}{r}0.40 \\
1.10 \\
2.72 \\
11.82\end{array}$ & $\begin{array}{r}1.77 \\
2.47 \\
4.00 \\
12.65\end{array}$ & $\begin{array}{r}14,413 \\
13,630 \\
11,682 \\
7,729\end{array}$ & $\begin{array}{r}57.85 \\
89.43 \\
96.00 \\
100.00\end{array}$ & $\begin{array}{l}4.83 \\
6.68 \\
7.50 \\
9.35\end{array}$ & $\begin{array}{l}0.40 \\
0.68 \\
0.82 \\
1.26\end{array}$ & $\begin{array}{l}1.77 \\
2.02 \\
2.15 \\
2.51\end{array}$ & $\begin{array}{l}14,413 \\
14,134 \\
13,979 \\
17,7,29\end{array}$ \\
\hline Total & $100.00^{\circ}$ & 9.35 & $\begin{array}{r}1.26 \\
3\end{array}$ & $\begin{array}{r}2.57 \\
8 \text { 1nch }\end{array}$ & $\begin{array}{l}13,729 \\
9.5 \mathrm{~mm})\end{array}$ & 200 mesh & & & & \\
\hline $\begin{aligned}-1.30 \\
1 . ? 0 \cdot 1.40 \\
1.40-1.60 \\
+1.60\end{aligned}$ & $\begin{array}{r}62.13 \\
26.50 \\
6.35 \\
5.02\end{array}$ & $\begin{array}{r}4.70 \\
9.98 \\
18.99 \\
56.93\end{array}$ & $\begin{array}{r}0.35 \\
1.04 \\
2.82 \\
12.82\end{array}$ & $\begin{array}{r}1.77 \\
2.47 \\
3.91 \\
13.06\end{array}$ & $\begin{array}{r}14,432 \\
13,639 \\
11,592 \\
7,228\end{array}$ & $\begin{array}{r}62.13 \\
88.63 \\
94.98 \\
100.00\end{array}$ & $\begin{array}{l}4.70 \\
6.28 \\
7.13 \\
9.63\end{array}$ & $\begin{array}{l}0.35 \\
0.58 \\
0.73 \\
1.31\end{array}$ & $\begin{array}{l}1.77 \\
1.97 \\
2.10 \\
2.65\end{array}$ & $\begin{array}{l}14,432 \\
14,195 \\
14,021 \\
13,680\end{array}$ \\
\hline Total & 100.00 & 9.63 & $\begin{array}{ll}1.31 & \\
& 14\end{array}$ & 2.65 & $\begin{array}{r}13,680 \\
.4 \mathrm{~mm}) \times\end{array}$ & 0 mesh & & & & \\
\hline $\begin{aligned}-1.30 \\
1.50-1.40 \\
1.40-1.60 \\
+1.60\end{aligned}$ & $\begin{array}{r}59.60 \\
28.60 \\
6.40 \\
5.40\end{array}$ & $\begin{array}{r}3.90 \\
10.16 \\
21.45 \\
52.35\end{array}$ & $\begin{array}{r}0.23 \\
0.72 \\
2.90 \\
12.60\end{array}$ & $\begin{array}{r}1.62 \\
2.02 \\
4.12 \\
14.69\end{array}$ & $\begin{array}{r}14,553 \\
13,612 \\
11,557 \\
7,621\end{array}$ & $\begin{array}{r}59.60 \\
88.20 \\
94.60 \\
100.00\end{array}$ & $\begin{array}{l}3.90 \\
5.93 \\
6.98 \\
9.43\end{array}$ & $\begin{array}{l}0.23 \\
0.39 \\
0.56 \\
1.21\end{array}$ & $\begin{array}{l}1.62 \\
1.75 \\
1.91 \\
2.60\end{array}$ & $\begin{array}{l}11,553 \\
14,248 \\
14,066 \\
13,718\end{array}$ \\
\hline Tocal & 100.00 & 9.43 & 1.21 & $\begin{array}{r}2.60 \\
\text { Dof Floor }\end{array}$ & $\begin{array}{l}13,718 \\
\text { Dilutio }\end{array}$ & 20 Percen & by We1g & & & \\
\hline+1.90 & 20.00 & 73.50 & 10.50 & 11.80 & 3,300 & & & & & \\
\hline
\end{tabular}


Table 4-6

PITTSBURGH SEAM COAL

WASHABILITY CHARACTERISTICS WITH ROOF AND FLOOR DILUTION

\begin{tabular}{|c|c|c|c|c|c|c|c|c|c|c|}
\hline \multirow{3}{*}{$\begin{array}{c}\text { Specific } \\
\text { Gravity }\end{array}$} & \multicolumn{5}{|c|}{ Elementary Data } & \multicolumn{5}{|c|}{ Cumulat1ve Data } \\
\hline & \multirow{2}{*}{$\begin{array}{l}\text { Weight } \\
\text { Percent }\end{array}$} & \multirow{2}{*}{$\begin{array}{c}\text { Ash } \\
\text { Percent }\end{array}$} & \multicolumn{2}{|c|}{ Sulfur } & \multirow{2}{*}{$\begin{array}{c}\mathrm{HHV} \\
\mathrm{Btu} / \mathrm{lb}\end{array}$} & \multirow{2}{*}{$\begin{array}{l}\text { Weight } \\
\text { Percent }\end{array}$} & \multirow{2}{*}{$\begin{array}{c}\text { Ash } \\
\text { Percent }\end{array}$} & \multicolumn{2}{|c|}{ Sulfur } & \multirow{2}{*}{$\begin{array}{c}\mathrm{HHV} \\
\mathrm{Btu} / 1 \mathrm{~b}\end{array}$} \\
\hline & & & $\begin{array}{l}\text { Pyritic } \\
\text { Percent }\end{array}$ & $\begin{array}{c}\text { Total } \\
\text { Percent }\end{array}$ & & & & $\begin{array}{l}\text { Pyritic } \\
\text { Percent }\end{array}$ & $\begin{array}{c}\text { Total } \\
\text { Percent }\end{array}$ & \\
\hline & & & \multicolumn{4}{|c|}{1.5 inch $(38 \mathrm{~mm}) \times 200$ mesh } & & & & \\
\hline$-1 \cdot 30$ & 46.28 & 4.85 & 0.40 & 1.77 & 14,413 & 46.28 & 4.85 & 0.40 & 1.77 & 14,413 \\
\hline $1.30-1.40$ & 25.66 & 10.02 & 1.18 & 2.47 & 13,630 & 71.94 & 6.69 & 0.68 & 2.02 & 14,133 \\
\hline $1.40-1.60$ & 4.86 & 19.65 & 2.72 & 4.00 & 11,682 & 76.80 & 7.51 & 0.81 & 2.15 & 13,978 \\
\hline $1.60-1.80$ & 3.20 & 50.75 & 9.82 & 10.62 & 8,510 & 80.00 & 9.24 & $1.17^{\circ}$ & 2.49 & 13,759 \\
\hline+1.80 & 20.00 & 73.50 & 10.77 & 12.09 & 3,179 & 100.00 & 22.09 & 3.09 & 4.41 & 11,643 \\
\hline Total & 100.00 & 22.09 & 3.09 & 4.41 & 11.643 & & & & & \\
\hline . & & & \multicolumn{4}{|c|}{$3 / 8$ 1nch $(9.5 \mathrm{~mm}) \times 200$ mesh } & & & & \\
\hline-1.30 & 49.70 & 4.70 & 0.35 & 1.77 & 14,432 & 49.70 & 4.70 & 0.35 & 1.77 & 14,432 \\
\hline $1.30-1.40$ & 21.20 & 9.98 & 1.04 & 2.47 & 13,639 & 70.90 & 6.27 & 0.56 & 1.98 & 14,194 \\
\hline $1.40-1.60$ & 5.08 & 18.99 & 2.82 & 3.91 & 11,592 & 75.98 & 7.13 & 0.71 & 2.11 & 14,020 \\
\hline $1.60-1.80$ & 4.02 & 54.93 & 9.92 & 10.62 & 8,358 & 80.00 & 9.53 & 1.17 & 2.54 & 13,316 \\
\hline+1.80 & 20.00 & 73.50 & 11.07 & 12.24 & 4,759 & 100.00 & 22.32 & 3.15 & 4.48 & 11,603 \\
\hline : Total: & 100.00 & 22.32 & 3.15 & 4.48 & 11,603 & & & & & \\
\hline$\therefore$ & & & . $\quad 14$ & mesh ( 1 . & $\mathrm{mm}) \mathrm{x}$ & 00 mesh & & & & \\
\hline$=1.30$ & 47.68 & 3.90 & 0.23 & 1.62 & 14,553 & .47 .68 & 3.90 & 0.23 & 1.62 & 14,553 \\
\hline $1.30-1.40$ & 22.88 & 10.16 & 0.72 & 2.02 & 13,611 & 70.56 & 5.93 & 0.39 & 1.75 & 14,247 \\
\hline $1.40-1.60$ & 5.12 & 21.45 & 2.90 & 4.12 & 11,557 & 75.68 & 6.98 & 0.56 & 1.91 & 14,065 \\
\hline $1.60-1.80$ & 4.32 & 50.35 & 9.60 & 10.40 & 8,480 & 80.00 & 9.32 & 1.05 & 2.37 & 13,763 \\
\hline+1.80 & 20.00 & 73.50 & 11.10 & 12.72 & 3,118 & 100.00 & 22.15 & 3.06 & 4.44 & 11,634 \\
\hline Total & 100.00 & 22.15 & 3.06 & 4.44 & & & & & & \\
\hline
\end{tabular}


Table 4-7

KENTUCKY NO. 9 SEAM COAL

WASHABILITY CHARACTERISTICS WITHOUT ROOF AND FLOOR DILUTION

\begin{tabular}{|c|c|c|c|c|c|c|c|c|c|c|}
\hline \multirow[b]{3}{*}{$\begin{array}{l}\text { Specific } \\
\text { Gravity }\end{array}$} & \multicolumn{5}{|c|}{ Elementary Data } & \multicolumn{5}{|c|}{ Cumulative Data } \\
\hline & \multirow[b]{2}{*}{$\begin{array}{l}\text { Weight } \\
\text { Percent }\end{array}$} & \multirow[b]{2}{*}{$\begin{array}{c}\text { Ash } \\
\text { Percent }\end{array}$} & \multicolumn{2}{|c|}{ Sulfur } & \multirow[b]{2}{*}{$\begin{array}{l}\mathrm{HHV} \\
\mathrm{Btu} / 1 \mathrm{~b}\end{array}$} & \multirow[b]{2}{*}{$\begin{array}{l}\text { Weight } \\
\text { Percent }\end{array}$} & \multirow[b]{2}{*}{$\begin{array}{c}\text { Ash } \\
\text { Percent }\end{array}$} & \multicolumn{2}{|c|}{ Sulfur } & \multirow[b]{2}{*}{$\begin{array}{c}\text { HHV } \\
\text { Btu/1b }\end{array}$} \\
\hline & & & $\begin{array}{l}\text { Pyritic } \\
\text { Peicent }\end{array}$ & $\begin{array}{c}\text { Total } \\
\text { Prititil }\end{array}$ & & & & $\begin{array}{l}\text { Pyritic } \\
\text { Percent }\end{array}$ & $\begin{array}{c}\text { Total } \\
\text { Percent }\end{array}$ & \\
\hline & & & \multicolumn{4}{|c|}{1.5 Inch $(38 \mathrm{~mm}) \times 200$ mesh } & & & & \\
\hline $\begin{aligned}-1.30 \\
1.30-1.40 \\
1.40-1.60 \\
1.60-1.90 \\
+1.90\end{aligned}$ & $\begin{array}{r}52.25 \\
32.38 \\
4.75 \\
2.12 \\
8.50\end{array}$ & $\begin{array}{r}4.10 \\
9.00 \\
21.30 \\
36.40 \\
74.20\end{array}$ & $\begin{array}{l}0.50 \\
1.14 \\
2.65 \\
3.46 \\
4.33\end{array}$ & $\begin{array}{l}3.00 \\
3.41 \\
4.68 \\
7.16 \\
6.21\end{array}$ & $\begin{array}{r}13,880 \\
13,397 \\
10,601 \\
9,124 \\
3,618\end{array}$ & $\begin{array}{r}52.25 \\
84.63 \\
89.38 \\
91.50 \\
100.00\end{array}$ & $\begin{array}{r}4.10 \\
5.97 \\
6.79 \\
7.48 \\
13.15\end{array}$ & $\begin{array}{l}0.50 \\
0.74 \\
0.76 \\
0.83 \\
1.28\end{array}$ & $\begin{array}{l}3.00 \\
3.16 \\
3.25 \\
3.34 \\
3.58\end{array}$ & $\begin{array}{l}13,880 \\
13,695 \\
13,530 \\
13,426 \\
12,592\end{array}$ \\
\hline Total & 100.00 & 13.15 & $\begin{array}{r}1.28 \\
?\end{array}$ & \multicolumn{2}{|c|}{$3 / 8$ inch $(9.5 \mathrm{~mm}) \times 200 \mathrm{mesh}$} & 200 mesh & & & & \\
\hline $\begin{array}{r}-1.30 \\
1.30-1.40 \\
1.40-1.60 \\
1.60-1.90 \\
+1.90\end{array}$ & $\begin{array}{r}54.87 \\
29.25 \\
6.00 \\
1.75 \\
8.13\end{array}$ & $\begin{array}{r}3.20 \\
8.60 \\
18.90 \\
39.60 \\
74.20\end{array}$ & $\begin{array}{l}0.40 \\
1.03 \\
2.12 \\
4.40 \\
4.68\end{array}$ & $\begin{array}{l}2.89 \\
3.29 \\
4.23 \\
5.74 \\
6.52\end{array}$ & $\begin{array}{r}13,959 \\
13,193 \\
11,755 \\
8,629 \\
3,618 .\end{array}$ & $\begin{array}{r}54.87 \\
84.12 \\
90.12 \\
91.87 \\
100.00\end{array}$ & $\begin{array}{r}3.20 \\
5.15 \\
6.06 \\
6.70 \\
12.19\end{array}$ & $\begin{array}{l}0.40 \\
0.62 \\
0.72 \\
0.79 \\
1.10\end{array}$ & $\begin{array}{l}2.89 \\
3.03 \\
3.11 \\
3.16 \\
3.43\end{array}$ & $\begin{array}{l}13,959 \\
13,692 \\
13,563 \\
13,469 \\
12,668\end{array}$ \\
\hline Total & 100.00 & 12.19 & \multicolumn{4}{|c|}{14 mesh $(31.4 \mathrm{~mm}) \times 200$ mesh } & & & & \\
\hline $\begin{aligned}-1.30 \\
1.30-1.40 \\
1.40-1.60 \\
1.60-19.0 \\
+1.90\end{aligned}$ & $\begin{array}{r}43.50 \\
35.24 \\
10.38 \\
2.25 \\
8.63\end{array}$ & $\begin{array}{r}2.70 \\
7.40 \\
19.40 \\
43.70 \\
74.20\end{array}$ & $\begin{array}{l}0.35 \\
0.84 \\
1.77 \\
1.93 \\
4.93\end{array}$ & $\begin{array}{l}2.81 \\
3.26 \\
3.53 \\
5.10 \\
6.69\end{array}$ & $\begin{array}{r}14,053 \\
13,378 \\
11,766 \\
9,174 \\
3,618\end{array}$ & $\begin{array}{r}43.50 \\
78.74 \\
84.12 \\
91.37 \\
100.00\end{array}$ & $\begin{array}{r}2.70 \\
1.80 \\
6.50 \\
7.12 \\
13.18\end{array}$ & $\begin{array}{l}0.35 \\
0.57 \\
0.71 \\
0.74 \\
1.10\end{array}$ & $\begin{array}{r}2.81 \\
3.01 \\
3.07 \\
3.12 \\
3.43\end{array}$ & $\begin{array}{l}14,053 \\
13,750 \\
13,519 \\
13,412 \\
12,255\end{array}$ \\
\hline Total & 100.00 & 13.18 & 1.10 & $\begin{array}{r}3: 43 \\
\text { of-F10o }\end{array}$ & $\begin{array}{l}12,255 \\
\text { Dilutio }\end{array}$ & 20 Perc & by w & & & \\
\hline+1.90 & 20.00 & 75.30 & 4.60 & 6.40 & 3,100 & & & & & \\
\hline
\end{tabular}


Table 4-8

KENTUCKY NO. 9 SEAM COAL

WASHABILITY CHARACTERISTICS WITH ROOF AND FLOOR DILUTION

\begin{tabular}{|c|c|c|c|c|c|c|c|c|c|c|}
\hline \multirow{3}{*}{$\begin{array}{l}\text { Specific } \\
\text { Gravity }\end{array}$} & \multicolumn{5}{|c|}{ Elementary Data } & \multicolumn{5}{|c|}{ Cumulative Data } \\
\hline & \multirow{2}{*}{$\begin{array}{l}\text { Weight } \\
\text { Percent }\end{array}$} & \multirow{2}{*}{$\begin{array}{c}\text { Ash } \\
\text { Percent }\end{array}$} & \multicolumn{2}{|c|}{ Sulfur } & \multirow{2}{*}{$\begin{array}{c}\mathrm{HHV} \\
\mathrm{Btu} / \mathrm{lb}\end{array}$} & \multirow{2}{*}{$\begin{array}{l}\text { We1ght } \\
\text { Percent }\end{array}$} & \multirow{2}{*}{$\begin{array}{c}\text { Ash } \\
\text { Percent }\end{array}$} & \multicolumn{2}{|c|}{ Sulfur } & \multirow{2}{*}{$\begin{array}{l}\mathrm{HHV} \\
\mathrm{Btu} / \mathrm{lb}\end{array}$} \\
\hline & & & $\begin{array}{l}\text { Pyritic } \\
\text { Percent }\end{array}$ & $\begin{array}{l}\text { Total } \\
\text { Percent }\end{array}$ & & & & $\begin{array}{l}\text { Pyritic } \\
\text { Percent }\end{array}$ & $\begin{array}{c}\text { Total } \\
\text { Percent }\end{array}$ & \\
\hline & & & \multicolumn{4}{|c|}{1.5 inch $(38 \mathrm{~mm}) \times 200$ mesh } & & & & \\
\hline-1.30 & 41.80 & 4.10 & 0.50 & 3.00 & 13,880 & 41.80 & 4.10 & 0.50 & 3.00 & 13,880 \\
\hline $1.30-1.40$ & 26.70 & 9.00 & 1.14 & 3.41 & 13,397 & 68.50 & 6.01 & 0.75 & 3.16 & 13,692 \\
\hline $1.40-1.60$ & 3.80 & 21.30 & 2.65 & 4.68 & 10,601 & 72.30 & 6.81 & 0.85 & 3.24 & 13,529 \\
\hline $1.60-1.90$ & 1.70 & 36.40 & 3.46 & 7.16 & 9,124 & 74.00 & 7.49 & 0.91 & 3.33 & 13,428 \\
\hline+1.90 & 26.00 & 74.20. & 4.33 & 6.21 & 3,618 & 100.00 & 24.83 & 1.80 & 4.08 & 10,878 \\
\hline Total & 100.00 & 24.83 & 1.80 & 4.08 & 10,878 & & & & & \\
\hline & & & \multicolumn{4}{|c|}{$3 / 8$ inch $(9.5 \mathrm{~mm}) \times 200$ mesh } & & & & \\
\hline-1.30 & 43.90 & 3.20 & 0.40 & 2.89 & 13,959 & 43.90 & 3.20 & 0.40 & 2.89 & 13,959 \\
\hline $1.30-1.40$ & 23.40 & 8.60 & 1.03 & 3.29 & 13,193 & 67.30 & 5.08 & 0.62 & 3.03 & 13,693 \\
\hline $1.40-1.60$ & 4.80 & 18.90 & 2.12 & 4.23 & 11,755 & 72.10 & 6.00 & 0.72 & 3.11 & $13 ; 564$ \\
\hline $1.60-1.90$ & 1.40 & 39.60 & 4.40 & 5.74 & 8,629 & 73.50 & 6.64 & 0.79 & 3.16 & 13,470 \\
\hline+1.90 & 26.50 & 74.20 & 4.68 & 6.52 & 3,618 & 100.00 & 24.54 & 1.82 & 4.05 & 10,859 \\
\hline Total & 100.00 & 24.54 & 1.82 & 4.05 & 10,859 & & & & & \\
\hline & & & \multicolumn{4}{|c|}{14 mesh $(1.4 \mathrm{~mm}) \times 200$ mesh } & & & & \\
\hline-1.30 & 34.80 & 2.70 & 0.35 & 2.81 & 14,053 & 34.80 & 2.70 & 0.35 & 2.81 & 14,053 \\
\hline $1.30-1.40$ & 28.20 & 7.40 & 0.84 & 3.26 & 13,378 & 63.00 & 4.80 & 0.57 & 3.01 & 13,751 \\
\hline $1.40-1.60$ & 8.30 & 19.40 & 1.77 & 3.53 & 11,766 & 71.30 & 6.50 & 0.71 & 3.07 & 13,520 \\
\hline $1.60-1.90$ & 1.80 & 43.70 & 1.93 & 5.10 & 9,174 & 73.10 & 7.42 & 0.74 & 3.12 & 13,413 \\
\hline+1.90 & 26.90 & 74.20 & 4.92 & 6.69 & 3,618 & 100.00 & 25.38 & 1.83 & 4.08 & 10,778 \\
\hline Tota1 & 100.00 & 25.38 & 1.83 & 4.08 & 10,778 & & & & & \\
\hline
\end{tabular}




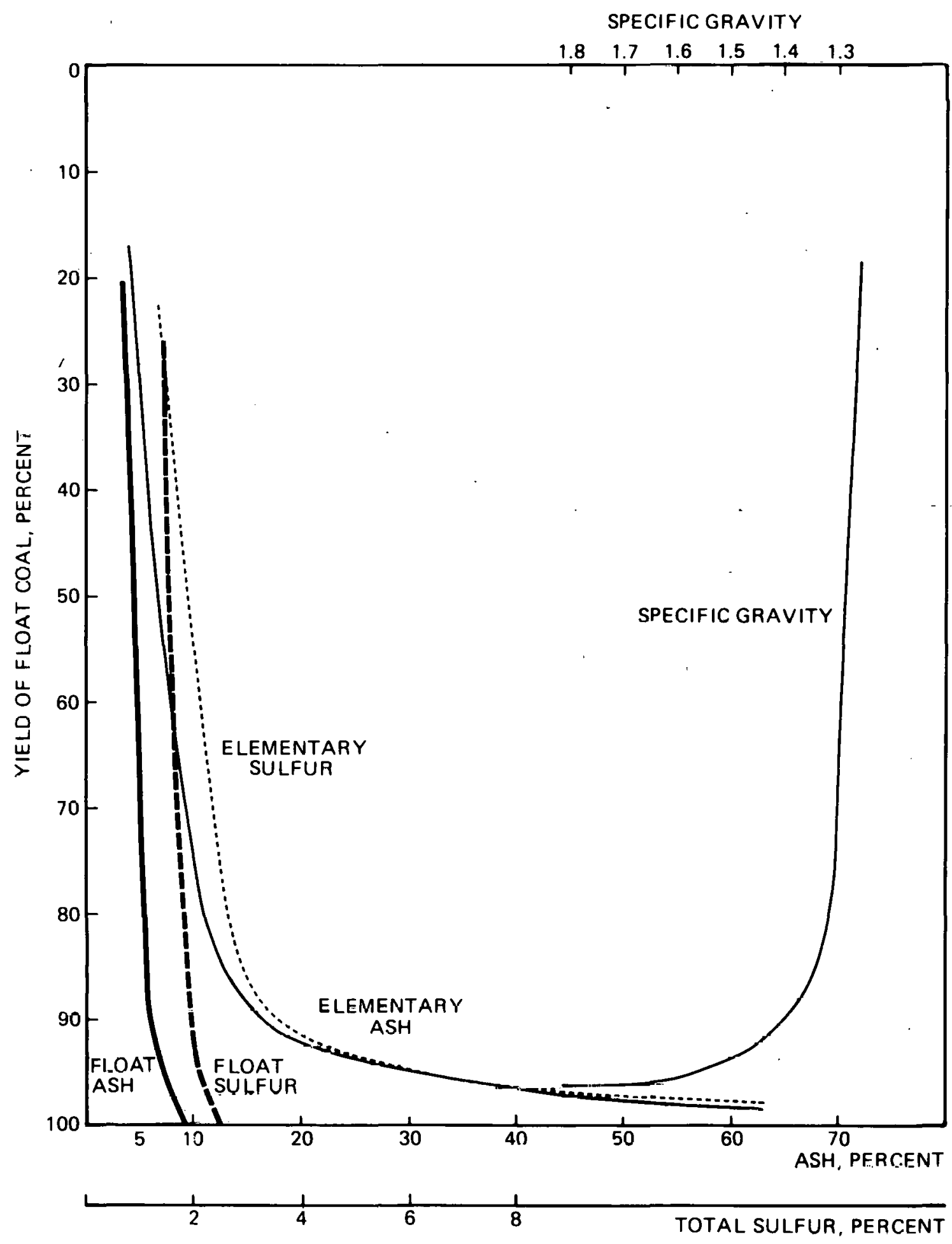

Figure 4-2 PITTSBURGH SEAM COAL WASHABILITY CHARACTERISTICS WITHOUT ROOF AND FLOOR DILUTION 


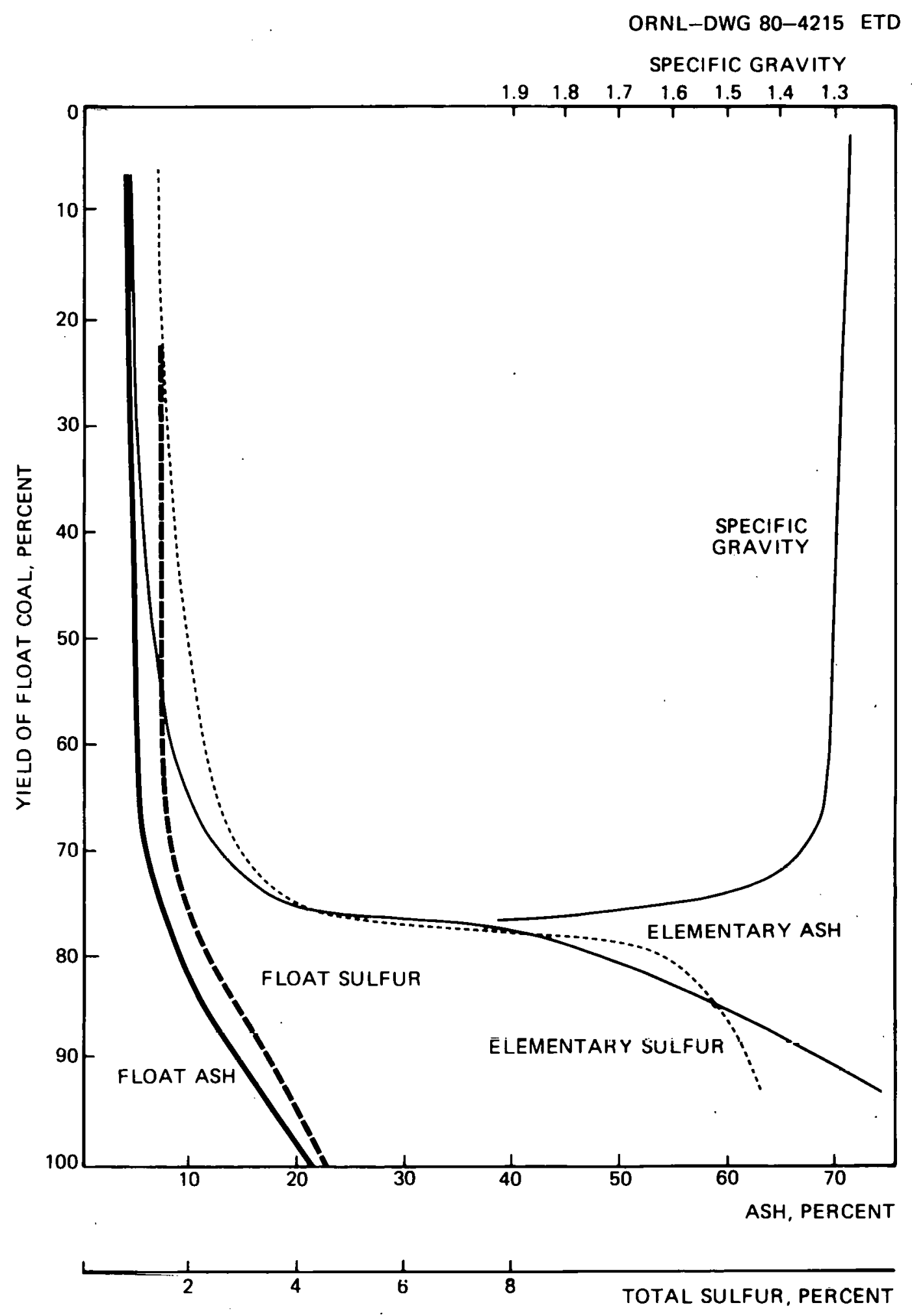

Figure 4-3 PITTSBURGH SEAM COAL WASHABILITY CHARACTERISTICS WITH ROOF AND FLOOR DILUTION 


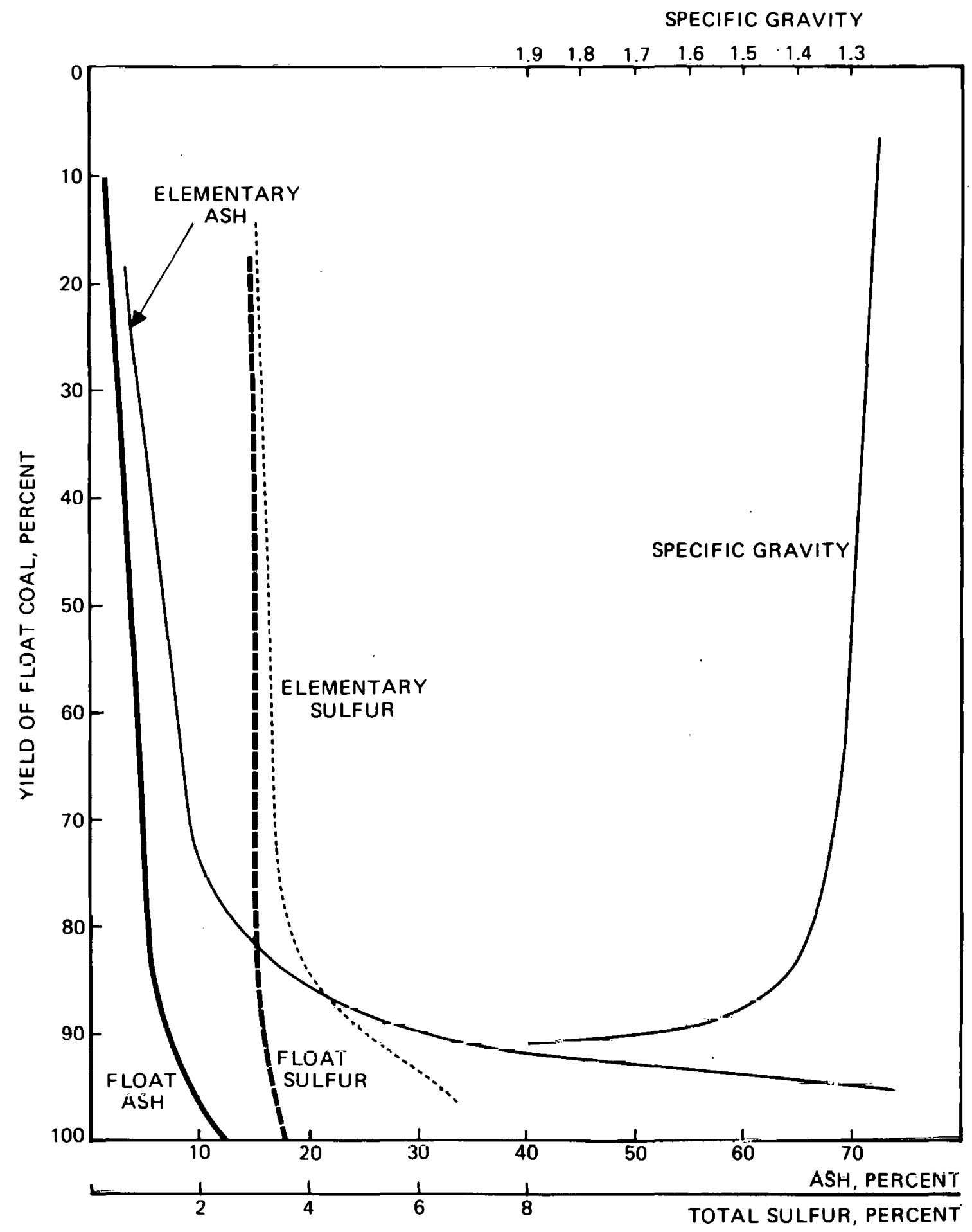

Figure 4-4 KENTUCKY NO. 9 SEAM COAL WASHABILITY CHARACTERISTICS WITHOUT ROOF AND FLOOR DILUTION 


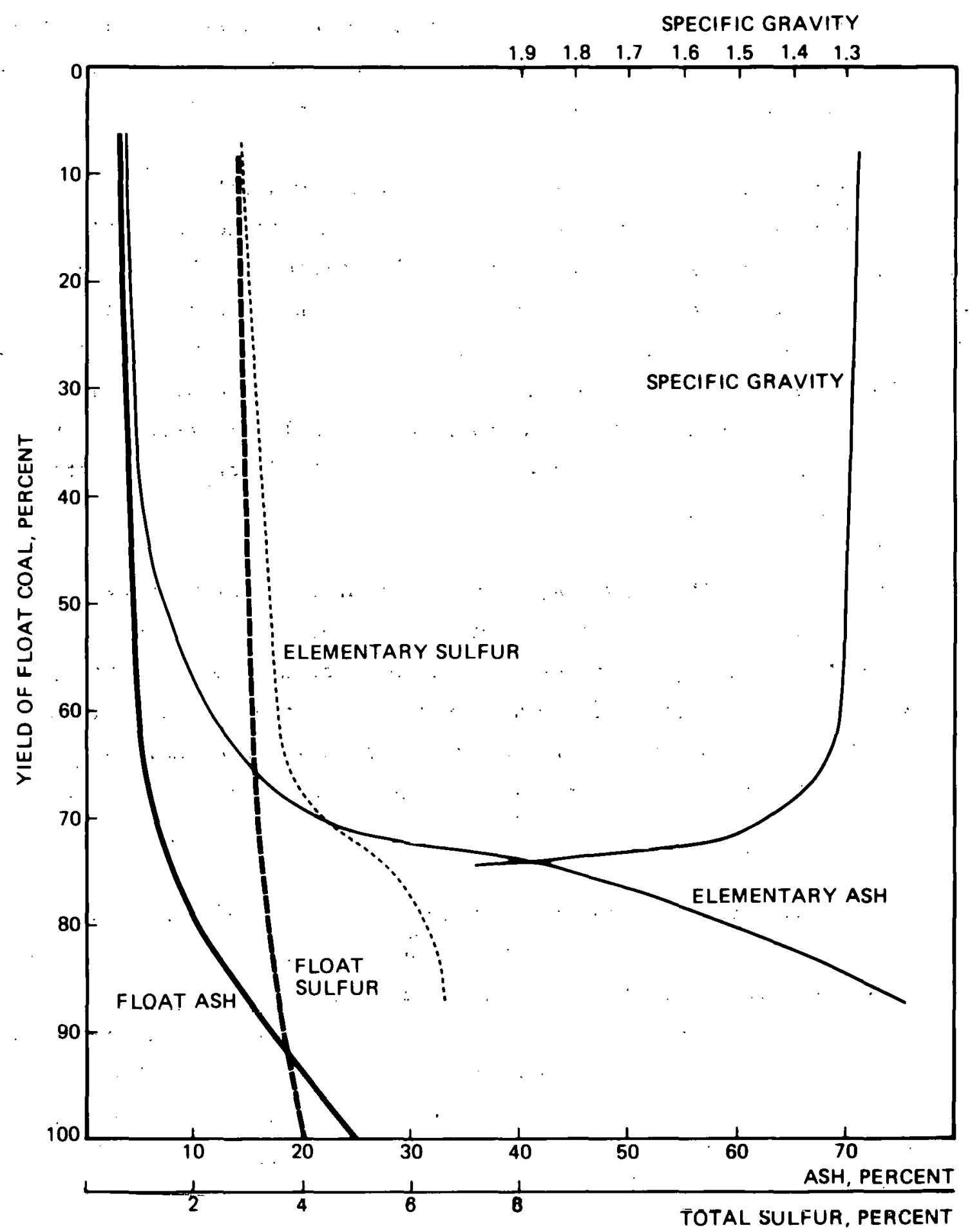

Figure 4-5 KENTUCKY NO. 9 SEAM COAL WASHABILITY CHARACTERISTICS WITH ROOF AND FLOOR DILUTION 
Coal washabilities based on channel samples have been adjusted to account for roof and floor dilution during mining. The adjusted washabilities are presented in Tables 4-6 and 4-8 and plotted in Figures 4-3 and 4-5.

The five curves presented on the washability plots show theoretical coal yield, ash content, and sulfur content as a function of the specific gravity at which the coalfloats. In these figures the term "float coal" is synonymous with clean coal. The float ash and sulfur curves are used to determine clean coal ash and sulfur contents as a function of theoretical yield. These two curves are plotted from the cumulative data presented in the washability tables. The elementary ash and sulfur curves show the witean ash and sulfur contents of each specific gravity fraction. Indicated in the washability tables.

Comparison of the specific gravity, float ash and float sulfur curves presented in Figures $4-3$ and $4-5$ shows that both coals as mined have very similar washability characterisitcs. In general, conclusions regarding the cleanability of one coal are valid for the other. Because of this, the washability data presented for the Pittsburgh Sean were used to develop the coal cleaning flow sheets material balances presented in Section 5 .

In both Figures 4-3 and 4-5, at below a specific gravity of approximately 1.5 , the float ash and sulfur curves become nearly vertical. This means that cleaning at lower specific gravities would not result in significantly improved ash or sulfur removal. Also, at below 1.5 specific gravity yi.elt begins to deteriorate rapidly for both coals. Because of the shape of the washability curves, use of heavy-medium cleaning would not result in significantly better cleaning performance than that expected by the cleaning flow sheets presented in section 5 . 
A considerable amount of research has been performed on both Pittsburgh and Kentucky No. 9 coals related to ash and sulfur removal using conventional coal cleaning methods. These methods are well developed and have been used commercially to clean both coals, but with emphasis on ash rather than sulfur removal. "Best" sulfur removals reported for both coals are on the order of 30 percent. Sulfur removal is limited by the fact that significant amounts of the sulfur in the two coals is present as organic sulfur and fine, widely disseminated pyritic sulfur.

Design conditions, in addition to washability data, used in development of coal cleaning flow sheets and material balances are presented in Table 4-9. Run-of-mine coal size consist data used to estimate a split between coarse and fine coal fractions are presented in Figure 4-6. Each line represents a size analysis for a specific bituminous coal sample broken to a top size of 3 to 6 inches; the feed coal size selected for cleaning. Mean values were used to estimate flow sheet size splits. For example, screening of coal at $1 / 2$ inch results in an approximate coarse/fine coal split of 65 percent/35 percent.

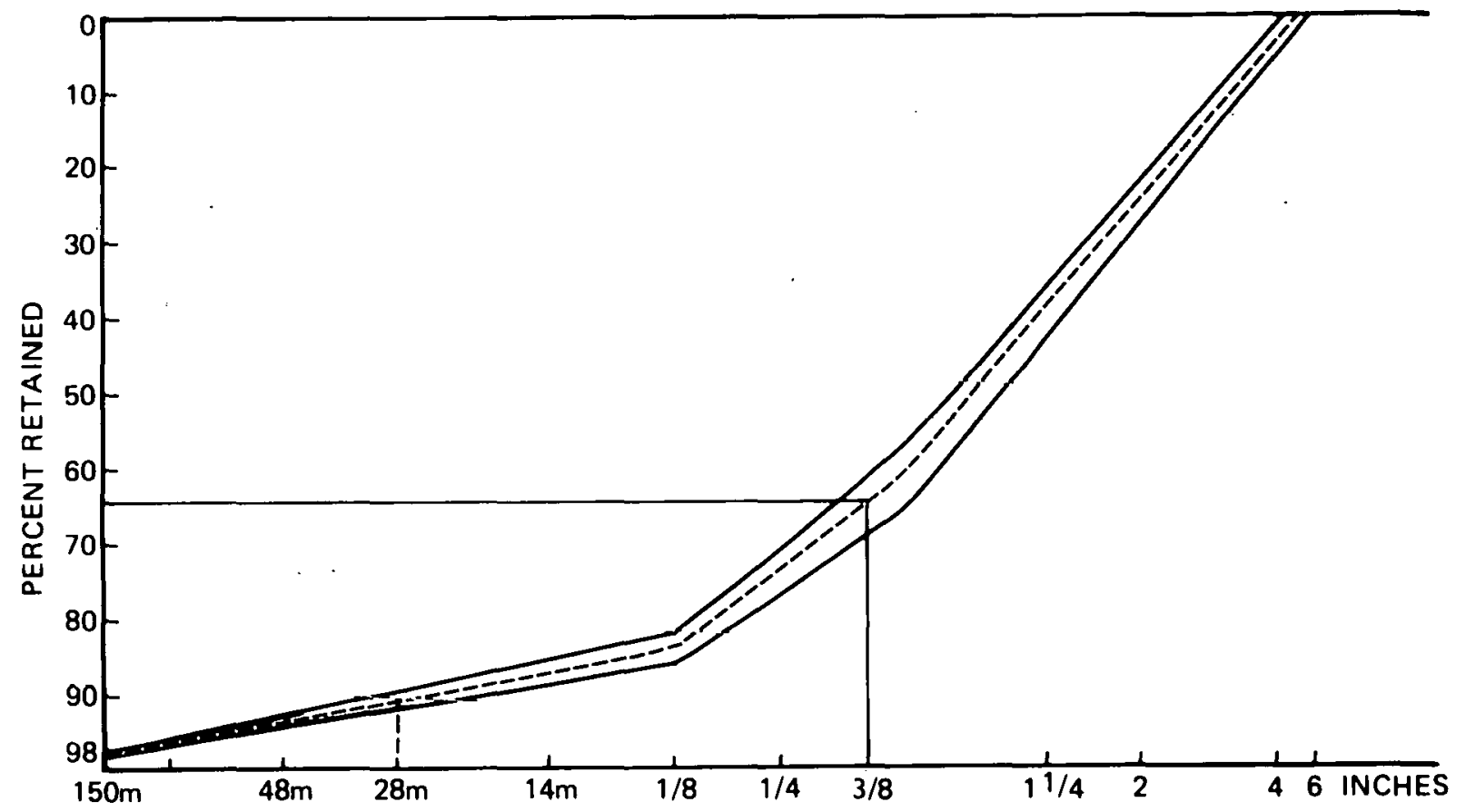

Figure 4-6 ESTIMATED BROKEN COAL SIZE CONSIST 
Table 4-9

COAL CLEANING FLOW SHEETS DESIGN CONDITIONS

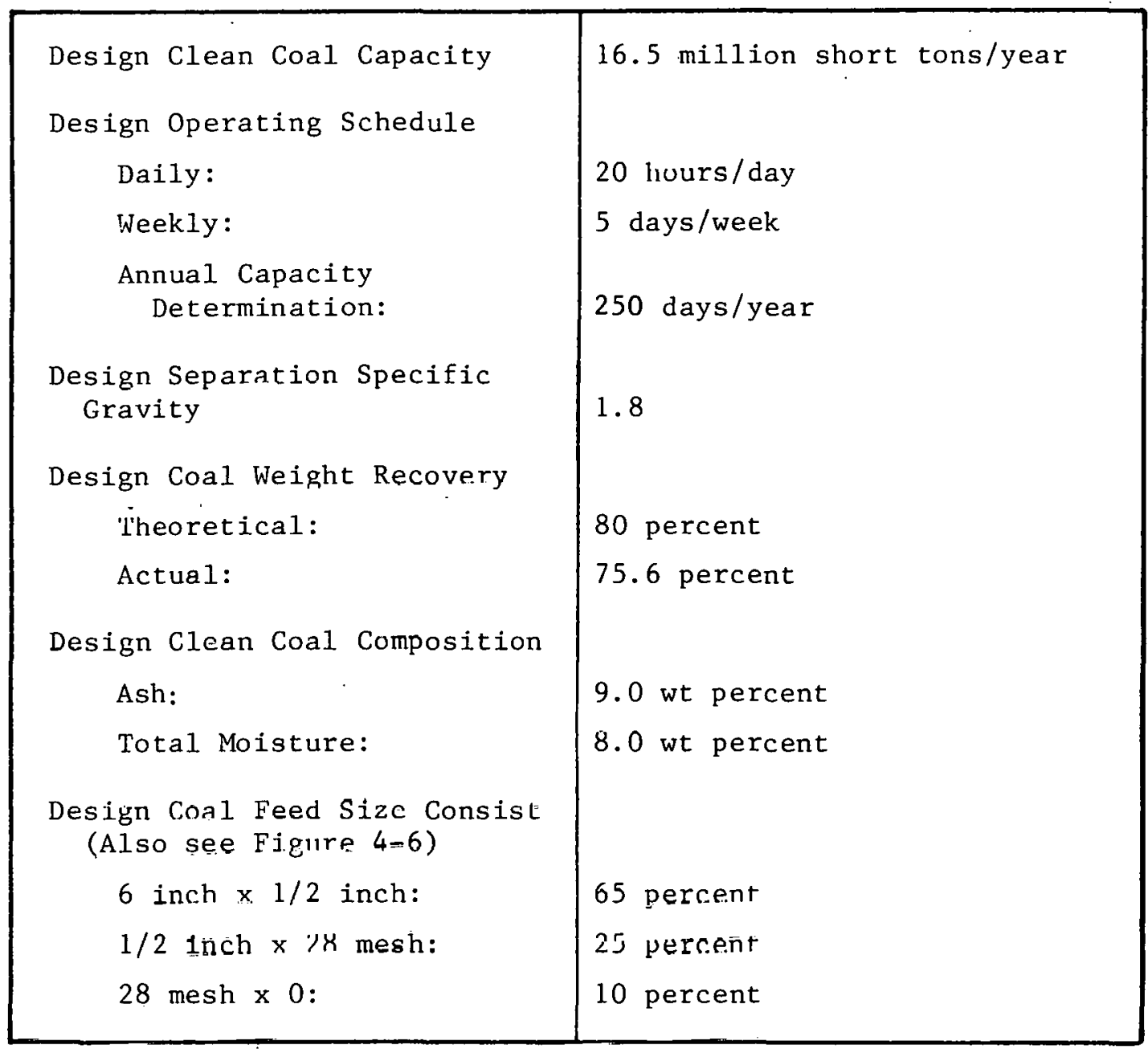


Coal cleaning plant annual operation is specified as 250 days per year. This annual operation is consistent with current coal cleaning and mining practice. If annual mine operation could be increased in the future, a cleaning plant with a smaller hourly throughput than that resulting from the Table 4-9 calculations could be used.

\subsubsection{Power/Steam Plant Coal Requirements}

Many current conceptual designs for commercial-scale coal conversion plants using the processes identified in Tables 4-1 and 4-2 include large power/ steam plants or require purchase of large quantities of electricity. The coal requirements for either onsite power/steam generation or for purchased electricity generation is frequently of sufficient magnitude that common integrated facilities for both power/steam and conversion coal handlingpreparation appear to be economically attractive. Because of this, several commercial-scale conversion plant conceptual designs were reviewed to roughly estimate the quantity of coal-generated electricity and process steam that might be required for conversion of 50,000 tons per day of coal.

Results of the brief electricity and steam. requirements survey are presented in Table.4-10. These estimates are very approximate and are dependent on the specific conceptual designs from which they were developed. Further, the estimates are not based on detailed evaluation of conversion plant material and enthalpy balances nor electricity requirements, but on summary information presented in the cited references.

Insufficient information was found for two processes: U-Gas and Exxon Catalytic Gasification. However, from brief review of information for the proposed Memphis Light, Gas and Water Division - DOE Industrial Fuel Gas Demonstration Plant (8), it appears that the U-Gas process may require only limited electricity or process steam from a coal-fired power/steam plant.

Estimated conversion processes total steam requirements range from zero for COGAS which uses extensive process energy recovery to 7.2 billion Btu/hour 
for H-Coal liquefaction. These steam requirement estimates do not include electricity for the coal handling-preparation operations covered by this report or for coal mining. For SRC-II, an additional $115 \mathrm{MW}$ of electricity is estimated to be required for coal handling-preparation and for operation of an integrated coal mine complex located adjacent to the conversion plant site. Total estimated power/steam plant steam generation requirement for an SRC-II plant is 6.8 billion Btu/hour. The quantity of coal required for such a power/steam plant is estimated to be 15 percent of that supplied to the conversion plant. This is equivalent to 7,500 tons per day of rnal. The 7,500 tons per day coal value has been used as the pnwer/steam plant coal requirement for conceptual flow sheets development.

For the conversion plant steam/power plant, Union Carbide specified use of an atmospheric pressure fluidized-bed steam generatur. This is consistent with the steam generator design selected for the DOE coal mine-coal conversion plant interface project. As a result, the basic steam generatur performance data developed for that project was used for preparation of the flow sheets presented in this report. The interface project steam/power plant dcsign was based on information provided directly to Bechtel by Foster Whccler Entsy corporation and information presented in the final report of the Gereral Electric Energy Conversion Altermatizrs Study(ECA3) sponsoren by ERDA, NASA, and the National Seience Foundation (NASA-CR 134949).

\subsection{CONCEPTUAL FLOW SHEETS DEVELOPMENT APPROACH}

Conceptual coal häliding-preparation and ash/slag removal flow sheets were dcveloped usling a modular approach. The resulting individual flow sheets can he joined in a variely of ways to obtain numerous alternative flow sheets which meet the coal feed and ash/slag removal requirenients of all nine specified coal conversion processes. As an aid for assessing alternative flow sheets and flow sheets description, a reference flow scheme has been defined. This reference flow scheme is for provision of coal to the SRC-II liquefaction process. 
SELECTED COAL CONVERSION PROCESSES ESTIMATED ELECTRICITY AND STEAM REQUIREMENTS(1)

\begin{tabular}{|c|c|c|c|c|c|c|c|c|}
\hline \multirow{3}{*}{$\begin{array}{l}\text { Process } \\
\text { No. }\end{array}$} & \multirow{3}{*}{ Conversion Process and Type } & \multicolumn{3}{|c|}{$\begin{array}{l}\text { Estimated Conversion } \\
\text { Process Requirement }\end{array}$} & \multirow{2}{*}{\multicolumn{2}{|c|}{$\begin{array}{c}\text { Reported Conversion } \\
\text { Process } \\
\text { Steam Conditions }\end{array}$}} & \multirow{2}{*}{$\begin{array}{c}\begin{array}{c}\text { Estimated Conversion } \\
\text { Process }\end{array} \text { Requirement } \\
\text { Total Steam } \\
{ }^{(3)}\end{array}$} & \multirow{3}{*}{ References $^{(5)}$} \\
\hline & & \multirow{2}{*}{$\frac{\text { Electricity }^{(2)}}{\mathrm{MW}}$} & \multicolumn{2}{|c|}{ Process Steam } & & & & \\
\hline & & & $\begin{array}{l}\text { Million } \\
\text { lb/hr }\end{array}$ & $\begin{array}{l}\text { Billion } \\
\text { Btu/hr }\end{array}$ & $\begin{array}{l}\text { Temperature } \\
Q_{F}\end{array}$ & $\begin{array}{l}\text { Pressure } \\
\text { psia }\end{array}$ & $\begin{array}{l}\text { Billion } \\
\text { Btu/hr }\end{array}$ & \\
\hline 2 & $\begin{array}{l}\text { COGAS } \\
\text { Fluldized-Bed Gasification }\end{array}$ & $\begin{array}{l}\text { In the current } c \\
\text { generation and } P \\
\text { fired power/stea }\end{array}$ & $\begin{array}{l}\text { AS commer } \\
\text { cess use } \\
\text { plant. }\end{array}$ & $\begin{array}{l}\text { plant c } \\
\text { obtained }\end{array}$ & $\begin{array}{l}\text { eptual design } \\
\text { m process hea }\end{array}$ & $\begin{array}{l}11 \text { steam re } \\
\text { recovery an }\end{array}$ & $\begin{array}{l}\text { red for electricity } \\
\text { ot from any coal- }\end{array}$ & 15 \\
\hline 3 & $\begin{array}{l}\text { HYGAS } \\
\text { Fluldized-Bed Gasification }\end{array}$ & 150 & 5.7 & 5.4 & 1,500 & 925 & 6.6 & 16 \\
\hline 4 & $\begin{array}{l}\text { Texaco Partial Oxidation } \\
\text { Entrained Flow Gasification }\end{array}$ & 210 & 3.0 & 2.9 & 1,500 & 925 & 4.5 & 16 \\
\hline 5 & $\begin{array}{l}\text { Exxon Donor Solvent } \\
\text { Liquefaction }\end{array}$ & 350 & 0 & 0 & - & - & 2.7 & 7 \\
\hline 8 & $\begin{array}{l}\text { SRC-II } \\
\text { Liquefaction }\end{array}$ & 550 & $\begin{array}{l}1.3 \\
0.4\end{array}$ & $\begin{array}{l}1.0 \\
\frac{0.3}{1.3}\end{array}$ & $\begin{array}{r}615 \\
75\end{array}$ & $\begin{array}{l}488 \\
308\end{array}$ & $\begin{array}{c}- \\
- \\
5.6\end{array}$ & 17 \\
\hline 9 & $\begin{array}{l}\text { H-Coal } \\
\text { Liquefaction } \\
\text { Mean Value }\end{array}$ & 410 & $\begin{array}{l}1.1 \\
0.5\end{array}$ & $\begin{array}{l}0.8 \\
\frac{0.3}{1.1} \\
2.1\end{array}$ & $\begin{array}{r}615 \\
75\end{array}$ & $\begin{array}{l}488 \\
308\end{array}$ & $\begin{array}{c}- \\
- \\
7.2 \\
5.3\end{array}$ & 17 \\
\hline
\end{tabular}

Notes: (1) All estimates are for a coal conversion plant converting 50,000 tons/day of coal having a higher heating value of 11,320 Btu/1b-dry. (2) This excludes any electricity required for coal handing, preparation, and mining.

(3) A value of $7,769.5 \mathrm{Btu} / \mathrm{kW}$-hr was used to estimate steam required for generation of estimated conversion process electricity requirement. This value was developed from information presented in the General Electric Energy Conversion Altematives Study for a power plant using an atmospheric pressure fluidized-bed steam generator.

(4) Excludes COGAS Process.

(5) Presented in Report References section. 
THIS PAGE

\section{WAS INTENTIONALLY LEFT BLANK}


Figure 4-7 presents a block flow diagram which identifies the coal handlingpreparation operations for which conceptual flow sheets have been developed. It also shows the relationship between individual flow sheet modules or operations. Specific operations covered by the block flow diagram are grouped into four general areas: coal cleaning, coal storage and blending, coal fine crushing, and coal pulverizing or grinding. The heavy line running through the first three areas identifies operations which constitute the reference SRC-II flow scheme. FS numbers above the coal cleaning operations area and in other areas over individual operations are flow sheet numbers corresponding to these operations.

To develop Figure 4-7, three general coal size consist classes.were developed from consideration of coal feed requirements for the identified conversion processes and other coal conversion processes. The three classes are:

- Coarse Coal - Coal "containing particles greater than $1 / 4$ inch in size

- Fine Coal - Coal containing particles not greater than $1 / 4$ inch, but not containing particles all smaller than 20 mesh in size

- Pulverized or Ground Coal - Coal which is 40 percent or greater minus 200 mesh in size

All of the conversion processes, except H-Coal liquefaction, require fine coal feed. H-Coal requires coal pulverized ur ground to nominally 70 percent minus 200 mesh. Coal delivered to the conversion plant from both coal source alternatives is coarse coal; 2 inches or larger top size.

Estimated capital investment for a nominal 50,000 tons per day coal conversion plant is several billion dollars. Most of this cost is associated with actual coal convcrsion, product(s) upgrading, and environmental emission control facilities. Because of this large investment and the quantity of

\section{Preceding page blank $4-43$}


product(s) produced, any unplanned interruption in conversion reactor coal feed would be extremely costly. In fact, this cost is of such magnitude that substantial investment in high reliability coal handling and preparation facilities would be fully justified. Therefore, in developing conceptual flow sheets, high operating reliability achievement was a prime consideration.

For proven processes, well engineered and constructed plants, and well managed plants, all of which were postulated, high operating reliability can be achieved by providing appropriate maintenance time or by equipment redundancy. Both approaches were used. For all operations before coal live storage (primarily coal cleaning) single conveyor lines, when practical, were deemed consistent with high operating reliability. These operations have an annual operating requirement of only 250 days (nominally 5 days per week). This is sufficient time for required maintenance. Also, the clean coal live storage design capacity specified is sufficient to accommodate most failures that could occur before live storage.

For coal live storage and all following coal operations redundant equipment is specified. These facilities must operate 365 days per year, 24 hours per day. The redundancy specitied is belleved sufficient to meet this requirement. Spare equipment and excess equipment capacity would be used to compensate for equipment out of service for maintenance or unscheduled repair.

Ány commercial coal conversion plaul will probably conoict of sereral identical, independent conversion trains. Both operating reliability considerations and equipment size limitations are principal reasons. Review of current commercial conversion plant conceptual design studies indicates that four to six :parallel conversion reactors (liquefaction reactors or gasifiers) appear reasonable for converting 50,000 tons per day of high rank bituminous coal. As a result, a cunversion plant consisting of five identical, parallel conversion reactors was used as a general basis for 


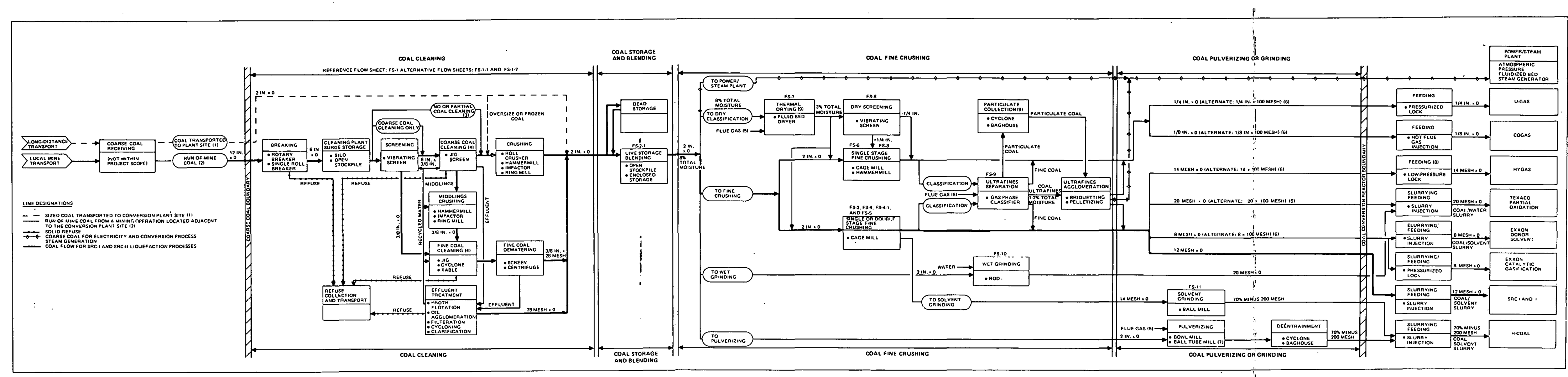

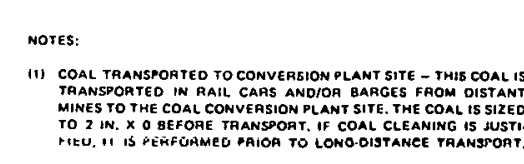

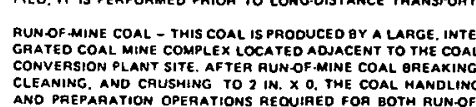

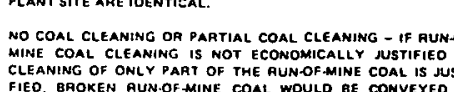

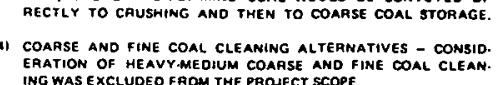

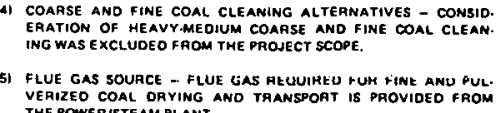

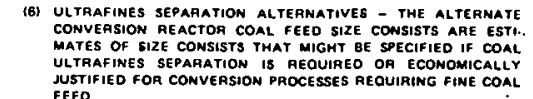

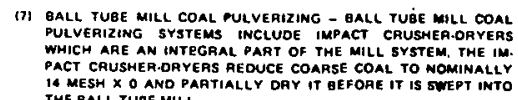

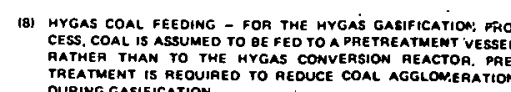

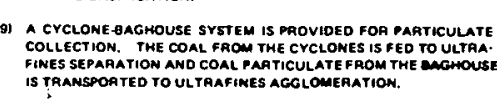

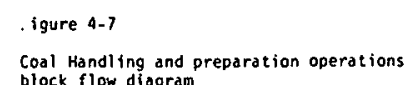


THIS PAGE

WAS INTENTIONALLY

LEFT BLANK 
flow sheets development. This, however, does not mean that following live storage all coal handling-preparation flow sheets consist of five identical, parallel, equipment trains. When acceptable reliability was judged possible, less than five coal handling-preparation trains are specified for supplying coal to five conversion reactor coal feed systems. Likewise, when current equipment capacity limitations indicate that more than five coal handling-preparation:trains would probably.be required, more than five are specified.

Establishment of best coal handling-preparation facilities designs for any of the nine specified coal conversion processes will require major tradeoff studics in several important areas. These trade-offs frequently involve whether or not a specific operation is justified for a coal conversion plant and, if so, the degree justified. Ultimately such justification becomes: a question of economics. The cost of these coal handling-preparation operations, both capital and operating costs, must be offset by cost savings in the actual conversion process or subsequent conversion plant operations. In addition to cost trade-offs associated with coal handlingpreparation operations reliability, major areas where trade-off assessment is required include coal cleaning, blending, and, in some case, conversion reactor coal feed requirements.

Unfortunately for many conversion processes, the process data required to assess the economic trade-offs between not obvious coal handling-preparation operations and actual conversion operations has yet to be developed. That is, conversion process data that would allow determination of the cost savings associated with converting, for example, blended versus unblended coal, simply blended versus fully blended coal, or cleaned versus uncleaned coal have generally not been developed. In using the conceptual flow sheets it should be recognized that at some point in development of coal conversion processes such trade-offs will be made. Their results could significantly affect design of actual coal conversion plant coal handling-preparation facilities. 
One area where limited trade-off assessments have been attempted is coal cleaning. Both Exxon Research and Engineering Company, for the Exxon Donor Solvent (EDS) Process, and Ashland Synthetic Fuels, Inc., for the H-Coal Process, have made preliminary investigations of potential coal cleaning benefits. For one version of the EDS process and an Illionois No. 6 coal, Exxon estimates that cleaning to approximately 9 wt percent ash could be justified. This preliminary conclusion is the result of an economic tradeoff between coal cleaning cost and the amount of $C_{1} / C_{2}$ product required to supplement plant requirements for low-Btu fuel gas produced by gasification of liquefaction solids. Ashland has indicated for one set of process conditions that approximately 8 wt percent ash appears justified.

\subsubsection{Coal Cleaning}

Run-of-mine coal received from the adjacent coal mine complex is broken from 12 inch $x 0$ to 6 inch $\times 0$, conveyed to cleaning plant surge storage, and then screened at $3 / 8$ inch. Screening at this size results in a coarse coal size consist that is well suited for a coarse coal cleaning $j$ ig. If screening were not used, minus $3 / 8$ inch coal would reduce coarse coal jig separation efficiency.

Jigs were the only conventional coarse coal cleaning method considered. The other possibility, heavy-medium cleaning, was excluded from consideration.

Three alternatives were considered for fine coal cleaning: fine coal jigs, water cyclones, and tabling. Fine coal cleaning flow sheets were developed for each of these alternatives.

Coal transported to the conversion plant site, if cleaned, was postulated to be cleaned, if justified, at the mine site or in regional cleaning plants serving several neighboring mines. Such cleaning would result in reduced coal transport costs and possibly lower cost disposal of cleaning plant refuse. Coal cleaning alternatives identified for the conversion plant site are applicable for any at mine and/or regional cleaning plants. 


\subsubsection{Coal Storage and Blending}

Main coal live and dead storage is provided after coal cleaning. Not only is the area required for storage reduced by refuse removal, but coal crushed to a nominal 2 inch top size is easier to handle and pack than coarser coal. Coal storage-blending facilities could also be located ahead of coal cleaning facilities. Advantages associated with this arrangement include reduced coal cleaning facilities surge storage requirement, possibly smaller cleaning facilities due to the possibility of longer annual operation, and cleaning of blended coal: In some situations, these advantages may outweigh those associated with live-dead storage after coal cleaning. The flow schemes and cleaning major equipment lists presented in this report are generally applicable" to both cleaning location alternatives.

Blending can improve operation of some types of coal cleaning plants, but those using cleaning methods identified in Figure 4-7 are not significantly improved. In fact, the identified methods accomplish some blending during cleaning. Heavy-medium coal cleaning would benefit most from feeding of blended coal. For coal conversion plants where heavy-medium cleaning is justified, the beneficial effects of cleaning blended coal may be of sufficient magnitude to justify location of live storage-blending ahead of coal cleaning.

In the coal mine-coal conversion plant interface evaluation project, a limited investigation was made of the cost trade-offs associated with different live storage facility design capacities. The main, but tentative and very situation-specific, conclusion of this investigation was that coal storage-blending facilities having live storage capactites sufficient to avoid any use of dead storage facilities, other than during emergencies, are less expensive to operate than those which normally require periodic use of dead storage facilities. The main reason for this conclusion is that when both capital and operating costs are considered, the cost per ton of moving coal in and out of dead storage is much higher than for a well designed live storage facility. 
Because of the live-dead storage economics conclusion resulting from the interface project, a live storage design capacity of 500,000 tons was established for conceptual flow sheets development. Analysis of probable differences between coal production by a mine complex located adjacent to a conversion plant site and actual conversion plant coal consumption on a daily basis indicates that this capacity is sufficient to limit any dead storage facility use to only emergency situations. Emergency situations are defined as no coal production or below planned production due to labor grievances, unforeseen mining conditions, or a mine disaster. The actual analysis was part of the interface project. For the particular conditions assumed, such as mine complex operation of 250 days per year and conversion plant operation of 365 days per year with 35 days maintenance allowance for individual conversion plant trains, this analysis showed that at live storage capacities below approximately 500,000 tons, coal had to be periodically moved in and out of dead storage to balance mine production with conversion plant consumption. This use of dead storage was not a consequence of any emergency situations. A graph of how live storage coal inventory could change with time over a period of 780 days is presented in the interface project final report. (1).

In addition to hopefully limiting any dead storage use to emergency situations, establishment of 500,000 tons as the live storage-blending design capacity allows identification of equipment limitations that might not be apparent at lower capacities. If adequate equipment is available for handling and blending 500,000 tons, it is available for lesser tonnages.

Dead coal storage is postulated to consist of multiple, carefully built, large plles bulle by mobile equipment; rubber-tired tractors and scrapers. After construction these piles, on-the-order of 250,000 tons of cna 1, are covered with an airtight seal of asphalt, road tar, or water-suluble acrylic polymer crusting agent. These piles are only reclaimed in emergency situations or where their age dictates. 


\subsubsection{Coal Fine Crushing}

Eight of the nine specified coal conversion processes require coal crushed to between $1 / 4$ inch $x 0$ and 20 mesh $x 0$. Further, the developers of processes requiring coal crushed to a top size of 8 mesh or finer indicate in various ways that "fines minimization" is required or is desirable. Just what constitutes "fines minimization", however, has apparently yet to be quantified by any of the process developers. It is likely that eventual establishment of specific coal fines or ultrafines limitations requirements will involve both technical and economic considerations. For most processes where fines are of concern, there appears to be a cost trade-off between fines removal before coal conversion and fines or fines products removal from conversion reactor products.

In developing coal fine crushing flow sheets, reduction of fines production was a prime consideration in equipment selection and selection of alternative fine crushing methods. In addition, a flow sheet for ultrafines separation following fine crushing was also developed. This flow sheet could be used with any of the actual fine crushing flow sheets if ultrafines removal is required or justified. To develop the ultrafines separation flow sheet, ultrafines were defined to be coal particles 100 mesh or finer in size. This definition is only an estimate of what individual process developers might ultimately define as ultrafines.

Coal fines can reportedly also be a problem in some types of proposed or existing fluidized-bed steam generators; the type of steam generators postulated for the conversion plant steam/power plant. Fines or ultrafines can be swept from the fluidized bed after only very short residence time. If this time is too short, these particles may not undergo complete combustion. And if particles containing appreciable heat value are not captured and returned to the fluidized bed or a carbon burnup cell, steam generator efficiency will be reduced. Some fluidized-bed steam generators reportedly eliminate or reduce to acceptable limits partial fines combustion by feeding coal below the fluidized bed rather than from the bed top. 


\subsubsection{Coal Pulverizing and Grinding}

Only one process in Table 4-1 requires pulverized coal; H-Coal. There are two obvious ways to meet this feed requirement: dry pulverizing and solvent grinding. Of these two approaches, dry coal pulverizing is a well developed technology, while coal solvent grinding has only been attempted experimentally.

Dry pulverizers (mills) are used exclusively for pulverized coal-fired steam generators, utility and industrial, and for many other coal-fired processes. Currently, several different designs of dry coal mills are commercially available. The individual capacities of these mills for bituminous coals range up to 100 tons per hour. Further, current dry mill. design can probably be scaled up, when markets such as coal conversion exist, to capacities in the 200 to 300 tons per hour range without sacrificing reliability. Mills of similar design to coal mills with capacities in excess of 300 tons per hour are currently used for pulverizing cement.

Conceptual designs and cost estimates were developed for two coal pulverizing alternatives in the coal mine-coal conversion plant: interface project. The flow sheets and major equipment lists, which are part of these conceptual designs, are believe to be adequate for Union Carbide's coal handlingpreparation equipment requirements survey. Therefore, no additional conceptual coal pulverizing flow sheets were developed.

With one exception, as far as could be determined, coal grinding, in coal liquefaction solvent, water, or other liquids has never been used in any large-scale commercial operation. There simply has never been any requirement for large-scale slurry coal grinding. Large-scale wet grinding, however, is widcly used in mineral ore beneficiation. Wet ore mills have been built with larger capacities than any dry coal mill. And, it is expected, on the basis of present design practices, that very large wet cnal milis could be built. Ball mills having 25 foot diameters and drive systems rated at $14,000 \mathrm{hp}$ are currently being considered for ore grinding. The ability 
to build very large wet mills could have a direct bearing on the minimum number of grinding lines in projected conversion plants and on their corresponding capital cost.

Wet grinding is used at the Black Mesa, Arizona, coal mine to prepare coal for slurry pipeline transport. The coal size consist produced at Black Nesa is, however, considerably coarser than the 70 percent minus 200 mesh size consist required for $\mathrm{H}-\mathrm{Coal}$ and is purposely skewed -16 to 20 percent minus 325 mesh and 30 to 35 percent plus 48 mesh. To accomplish this special size consist, open-circuit, rod mill grinding is used. From Black Mesa, slurried, ground coal is piped 273 miles to the 1,580-MW Mohave power plant. Here it is dewatered and pulverized further in conventional dry coal mills to a nominal size consist of 70 percent minus 200 mesh.

Kennedy Van Saun Corporation (KVS) is currently performing an extensive investigation of coal pulverizing and grinding for DOE. As part of this project, KVS has performed a limited amount of grinding tests using Kentucky No. 9 coal and No. 4 and No. 6 fuel oil. Results of this work were used to develop a single conceptual coal-solvent grinding flow sheet which matches H-Coal coal feed requirements ( 70 percent minus 200 mesh coal dried to 2.0 wt percent or less total moisture).

\subsubsection{Conversion Reactor Ash/Slag Removal}

All nine coal conversion processes specified produce significant quantities of solid wastes which must be disposed of in an environmentally acceptable manter. The main sources of these wastes are: conversion process gasifiers, power/steam plant steam generators, and coal cleaning operations. As discussed in Subsection 4.2, the liquefaction processes, with exception of SRC-I, gasify residues resulting from coal liquefaction and subsequent products recovery. The gasifiers used to gasify these fractionation bottoms produce the ash or slag wastes associated with liquefaction. Solid wastes resulting from SRC-I are the result of a liquefaction reactor liquids-solids 
separation operation. For flow sheets development, the SRC-I solids were assumed to be disposed of directly, i.e., they were not considered to be an acceptable gasifier feed.

Figure 4-8 presents possible operations that could be used for ash/slag removal. In reviewing the ash/slag operations required for each of the nine specified conversion processes, the possibility of energy recovery was evaluated. However, in all cases where it appeared warranted, it is already part of the conversion reactor (see Subsection 4.2). Therefore, only flow sheets for ash or slag dewatering, when required, and transport to a disposal site were developed.

To facilitate ash/slag removal flow sheets development two types of gasifier solid wastes were defined: granulated slag and ash. The type produced by specific gasifiers is shown in Figure 4-8. Granulated slag is formed by rapid quenching of molten gasifier slag in water. It is relatively coarse in size, typically contains less than $4 \mathrm{wt}$ percent combustibles, and dewaters easily. With the possible exception of U-Gas, ash from the ash producing gasifiers has a finer size consist that granulated slag and contains considerably more combustible material (principally carbon).

In both slagging and nonslagging gasifiers the possibility exists of ash/ slag removal channel pluggage due to tormation of agglomerates or oversize chunks of solidified slag. To prevent such pluggage some coal conversion process developers have proposed use of ash/slag crushers or grinders installed at appropriate locations in their gasifier ash/slag remnval syatems. In developing conceptual ash/slag removal flow sheets, any ash/slag crushers or grinders were considered to be part of the gasiffer and not part of ash/ slag removal, i.e., any crusher or grinders were considered to he on the gasifier side of the ash/slag handling hnundarifs defined in Subsection 1.2.1. If ash/slag crushers or grinders are used to control ash or granulated slag top size, for most gasifiers listed in Table 4-2 they would need to operate 


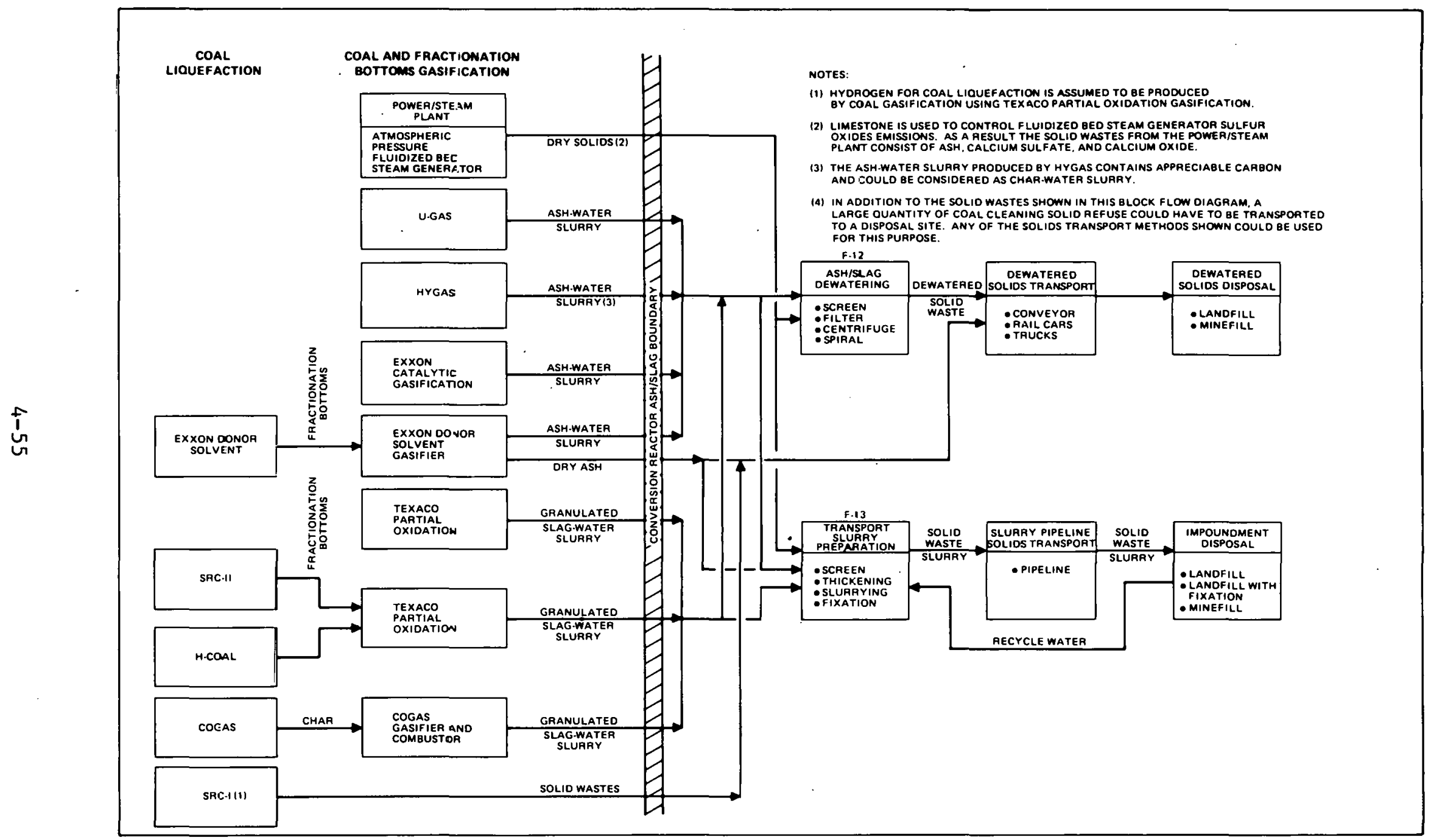

Fiqure 48

ASH/SLAG REMOVAL OPERATIONS BLOCK FLOW DIAGRAM (4) 


\section{THIS PAGE}

\section{WAS INTENTIONALLY \\ LEFT BLANK}


at or near gasifier operating pressure and. could be exposed to high temperatures. To reliably operate under these severe conditions new or modified ash/slag crusher or grinder designs may have to be developed and demonstrated.

In order to estimate equipment design capacities, the granulated slag and ash characteristics presented in Table 4-11 were adopted. In the case of ash producing gasifiers, the resulting material balances represent maximum values. The quantity of gasifier ash that would have to be disposed of decreases with ash combustibles concentration.

Table 4-11

\section{ESTIMATED GASIFICATION ASH AND GRANULATED \\ SLAG CHARACTERISTICS}

\begin{tabular}{|c|c|c|}
\hline Characteristic & $\begin{array}{c}\text { Ash Producing } \\
\text { Gasifiers }\end{array}$ & $\begin{array}{c}\text { Slagging } \\
\text { Gasifiers }\end{array}$ \\
\hline $\begin{array}{l}\text { Gasifier Siurry Solids } \\
\text { Concentration } \\
\text { Ash or Slag Combustible } \\
\text { Concentration } \\
\text { Dewatered Ash or Slag } \\
\text { Moisture Concentration }\end{array}$ & $\begin{array}{l}40 \text { wt percent } \\
30 \text { wt percent } \\
30 \text { wt percent }\end{array}$ & $\begin{array}{l}40 \text { wt percent } \\
2 \text { wt percent } \\
10 \text { wt percent }\end{array}$ \\
\hline
\end{tabular}

As presented in Table 4-9, coal feed to conversion reactors has an estimated ash concentration of 9.0 wt percent, wet basis. After allowance for coal diverted to the ponwer/steam plant $(7,500$ tons per day of clean coal), this results in a" combustibles free gasifier solids wastes production of 159 tons per hour.' When slág and ash combustibles concentrations are considered, the. following quantities are obtained for gasifier solids wastes production on a dry solids basis:

- Granulated slag producing gasifiers: 163 tons per hour $(3,912$ tons per day)

\section{Preceding page blank $4-37$}


- Ash producing gasifiers: 228 tons per hour $(5,472$ tons per day)

The 15 percent of conversion plant feed coal diverted to the power/steam plant is fired in atmospheric pressure fluidized-bed steam generators. To control flue gas sulfur oxides emissions, limestone is injected into these steam generators. As a result, 41 tons per hour (984 tons per day) of dry solid wastes having the following estimated composition would be produced in the power/steam plant:

\section{Component}

Ash

Calc1um Oxide

Calclum sulface

Residual Carbon

\section{Weight Percent}

63.5

14.5

20.6

1.4

If coal cleaning. is part of a conversion plant, large quantities of cleaning plant refuse would be produced. Cleaning refuse quantity estimated for flow sheets presented in this report for cleaning Pittsburgh Seam coal is 1,200 tons per hour (24,000 tons per day) at 15.7 wt percent total moisture. This is over five times the amount of solid wastes produced by the conversion process gasifiers. If coal cleaning were not used, much of this solid waste would be fed to the conversion reactors.

Numerous approaches are used to transport solids having characteristics similar to those estimated for conversion plant solid wastes. Obviously of importance in selecting a best approach is the dictancc wastes dite LU be transported. Therefore, a nnminal distanco of 5 milco was established for flow sheets development. This distance is judged to be reasonable for conversion plants located in areas underlain by either the Pittshurgh or Kentucky No. 9 coal seams. 
As shown in Figure 4- $\delta$, two general solid wastes transport approaches were judged suitable to handle the quantities of wastes that would result from coal conversion (on the order of 30,000 tons per day under the conditions established for flow sheets development); transport as dewatered solids and slurry pipeline transport. Selection of the best approach for a specific coal conversion plant would depend largely on economics. Major factors, in addition to waste quantities and transport distance, that would affect relative economics are:

- The type of disposal operation

- Terrain between the conversion plant site and the disposal site and at the disposal site

- Environmental requirements which must be met at the disposal site

- Solid wastes physical and chemical characteristics

As presented in Figure 4-8, two alternatives were considered as possible ultimate solid wastes disposal methods: landfill and underground mine fill. (Surface mine fill was considered analogous to landfill.) of these two alternatives, landfill would be the simplest and probably the least expensive approach at most sites provided necessary permits could be obtained. Filling of mined out portions of coal mines used to produce conversion coal would be complicated, particularly if longwall mining is used. As far as is known, no effort has ever been made in the United States to return the quantity of wastes that would be associated with coal conversion piants to coal mines. Considerable development/demonstration would be required before mine fill is considered feasible.

A considerable amount of materials handling could be required at the actual disposal site to meet environmental and aesthetic requirements. This would be particularly true for the dewatered wastes transport alternatives and underground mine fill disposal. Extensive environmental monitoring would also be required. Consideration, however, of materials handling operations at the disposal site was not within the scope of the work covered by this 
report. With the possible exception of equipment required for underground mine fill disposal, existing materials handling equipment, such as dozers and scrapers, are capable of meeting disposal site materials handling requirements.

Because of the presence of environmentally harmful compounds, some solid wastes may require special treatment before actual disposal. Wastes containing leachable compounds which are toxic or potential ground or surface water pollutants are apt to require such special treatment. Also, wastes containing compounds such as oils which can form films on water are also apt to require some treatment. One type of treatment that might be used to render environmentally harmful compounds safe for disposal is the addition of "fixing" agents such as lime, silicates, cement, or certain types of ash. These agents can, for some types of wastes, tie up physically or chemically harmful compounds in a solid matrix from which their leachability is very low. Use of such agents, some of which are proprietary, for large quantities of solid wastes is relatively" new, but a considerable amount of research is currently being done in this area. Fixation of sludges produred by lime and limestone flue gas sulfur oxides control processes is an example of one area where fixation is being seriously evaluated.

The solid wastes handing conceptual flow sheets are compatible with use of fixing should its use be required. However, no equipment is provided for addition and mixing of fixing compounds. 
Section 5

CONCEPTUAL FLOW SHEET DESCRIPTIONS

This section describes conceptual flow sheets for coal handling and preparation and ash/slag removal operations that will be required by commercial coal conversion plants. Accompanying these flow sheets are major equipment lists. Design bases established for the flow sheets and the general approach used in their development are presented in Section 4.

All flow sheets are keyed to the coal handling and preparation operations block flow diagram, Figure 4-7, or the ash/slag removal operations block flow diagram, F igure 4-8, presented in Subsection 4.3. F S designations on these block flow diagrams are flow sheet numbers. These numbers are located over the coal cleaning general operations area and over individual operations: When more than one single dash FS number, such as FS-3 and FS-4, are shown for an operation, multiple flow sheets are required to meet the coal feed requirements for all coal conversion processes. In general, flow sheets with double dash numbers, such as FS-4-1, are alternative flow sheets for specific operations.

Most flow sheet operations require multiple equipment of the same type. These are frequently arranged into independent trains consisting of several operations. In such flow sheets, only a single piece of equipment is shown. Numbers in parantheses after equipment titles are the actual equipment quantities required for a specific operation.

To facilitate presentation, this section is divided into subsections corresponding to the four general coal operation areas identified in the Figure 4-7. block"diagram, plus a subsection which presents ash/slag removal flow sheets. These subsections are preceded by some general qualifications. 


\subsection{FLOW SHEETS AND MAJOR EQUIPMENT LISTS GENERAL QUALIFICATIONS}

All coal flow sheets presented in this report involve handling and preparation of very large quantities of material. Only one United States coal mine, a western strip mine, currently produces the quantity of coal specified for these conceptual flow sheets; 16.5 million tons per year. None of the mines currently operating in either the P1ttsburgh or Western Kentucky coal seams have productions which even approach this tonnage. A coal-fired power plant capable of annually consuming 16.5 million tons of coal would have a capactty rating on the order of 6,200 MW. This is nearly twice the rated design capacity of the largest U.S. coal-fired power plants.

Design of facilities with the capacities dealt with in this report will require considerable engineering effort. Final equipment. selertinns and facilities designs will be the result of numerous trade-off studies involving both technical and economic considerations. Flow sheets and equipment specifications for these facilities will reflect the results of these studies and detailed engineering.

In comparison with the engineering effort required for actual plant design, that associated with the flow sheets and equipment lists presented in this report is small. Further, these flow sheets are not site-specific, provide cual fur nine different conversion prosesses plus fluidizcd-bed steam generators, and were developed without the aid of engineering drawings. As a result, flow sheets and equipment performance spectfications presented in this report should be used with discretion. The flow sheets and equipment performance specifications are based on engineering judgments, design exper= ience with similar coal and other materials handling-preparation facilities, information provided by equipment manufacturers, and information developed in other Bechtel coal conversion plant conceptual design projects.

Major. equipment lists presented contain estimated equipment design capacities and, where appropriate, such information as estimated installed 
equipment power, major overall dimensions, recommended materials of construction, specification requirements, and general comments. In the Specification Requirements and Comments part of these lists, frequent reference is made to equipment of "standard design." This term is used to identify equipment that is currently used commercially for coal operations at or above the equipment's specified design capacity. No further development or demonstration is required for reliable use of equipment so specified. However, because of capacity requirements, most equipment specified as standard would not be available as off-the-shelf items. Most would have to be custom fabricated from proven design data. As a result, purchase lead times required for standard equipment can be substantial even though no development or demonstration is required.

For selected major equipment that are repeatedly specified, general performance requirements specifications were prepared. These are presented in Appendix $A$ and equipment covered by them are identified in the equipment lists. The general performance requirements specifications are for large belt conveyors (including tripper conveyors), gravimetric belt feeders, and cage mill fine crushers.

As discussed at the beginning of Subsection 4.3, Conceptual Flow Sheet Development Approach, high operating reliability was a prime consideration in flow sheet development and equipment specification. All equipment specified in major equipment lists is considered to have high operating reliability or, through further development, be able to achieve high operating reliability. For individual pieces of equipment, high operating reliability was defined to mean an expected equipment annual availability of at least 90 percent. That is, maintenance requiring a piece of equipment to be taken out of service or not be available would not exceed 875 hours per year. 
Actual equipment reliability depends on four main factors, all of which must be adequate if high reliability is to be achieved. These are:

- Equipment design and manufacture including accessories and controls

- Plant design and construction - Equipment must be properly installed, adequate access provided for rapid maintenance, and acceptable service facilities, such as cranes, tools, and shops provided

- Consistent, thorough preventive maintenance

- Spare parts and maintenance materials inventories

In some plants, one or more of the latter three factors have been neglected. As a result, though all equipment is compatible with high operating reliability, high reliability is not achieved. Considering the costs associated with coal conversion, neglect of any reliability dependent factors would probably be economically disastrous.

Conveyors, fine crushers, feeders, pulverizers, and dryers of the types specified in this report have demonstrated high reliability in coal applications. In some flow sheets, large air classifiers, grinding mills, and baghouse particulate collectors are used. The reliability of this equipment has been demonstrated only in applications other than coal, principally in minerals beneficiation. Some design modifications or further development may be required for reliable use of this equipment in coal preparation.

In large scale materials handling-preparation, plant operating reliability is not dependent only on individual equipment reliability. The number of successive operations is frequently of such magnitude that provision of alternative flow paths, excess capacity equipment, redundant equipment, and storage facilities are required to guarantee high plant operating reliability. All four approaches are used in the conceptual coal handlingpreparation flow sheets. Particular use is made of full capacity redundant 
equipment such as conveyors. An important consideration in this approach is the reliability of equipment, such as flop gates, used to alter coal flow path.

Determination of the best approach to obtain a specific plant operating reliability when individual equipment operating reliability can be adequately predicted is a complicated problem and is an area where additional research could result in economic benefits for large-capacity coal handling and preparation. As a result, the flow sheets presented in this report, though based on actual plant experience, do not necessarily represent optimum designs. Much remains to be learned about the best way to engineer large capacity coal handling-preparation facilities. In this regard, reliability evaluations of existing operations, such as power plant coal handlingpreparation facilities, could provide data for improved future coal conversion plant designs. Equipment and plant reliability assessment should also be part of all coal conversion plant demonstration programs.

In the equipment lists presented in this report, design capacities are. shown for coal surge storage silos and bins. These capacity values are only rough estimates. Extensive equipment layout studies, coal flow design calculations, structural analysis, and cost estimating would be required to arrive at final design dimensions and capacities for coal silos and bins of types and capacities specified for conversion coal storage. All bins and silos would be designed for mass flow operation. This flow pattern results in a first-in and first-out flow sequence which minimizes coal size segregation as a result of storage and avoids spontaneous combustion fires due to formation of dead regions within bins and silos. To avoid fires, coal would not be held in any surge storage silos or bins for prolonged periods. Though not shown on flow sheets, all bins dis-. charging to crushing would be equipped with emergency unloading chutes. If for some reason a bin could not be emptied normally or a fire were to occur, they could be quickly and safely emptied by means of these chutes. 
In the conceptual flow sheets extensive use is made of large-capacity belt conveyors. Design of conveyor systems of the capacity specified, like design of storage bins and silos, requires extensive layout studies and design calculations. In fact, conveyor design is greatly affected by storage requirements and is a principal cost associated with storage facilities. Bin and silo heights frequently determine the length of conveyors and obviously affect conveyor power requirements. Because of the engineering required to completely specify conveyor systems, conveyor power requirements presented in the equipment lists are only rough estimates. Conveyor belt widths are also estimates, but are not as subject to change as much as the conveyor power estimates.

Transfer of coal between operations, such as from conveyors into bins, from bins onto feeders, and from crushers onto conveyors, usually requires use of metal-enclosed chutes. The shapes of these chutes can be quite elaborate and, in addition to their containment function, they may contain flop gates or other solids diversion devices for flow direction switching and sampling equipment. The conceptual flow sheets presented in this report do not show chutes or, with minor exception, how chutes would be used to divert coal to alternative or parallel equipment. The existence of suitably designed chutes and associated equipment is only implied in these flow sheets. Their design, however, is an important part of the engineering of large, high reliability coal handling-preparation facilities.

An important requirement in all coa thanding operations is particulates control. Baghouse dust collection systems are specified for this purpose for coal surge storage and for coal breaking. Actual sizing of these systems depends on the dimensions of the structure they serve, the amount of coal involved, the operation rcsulting in dust creation, and coal size 
consist. Since the flrst two are plant layout dependent, the baghouse design capacities and power requirements specified in the equipment lists are only rough estimates.

A problem associated with use of baghouses for coal particulates control is coal dust explosion. Though development-demonstration is required, it is believed that coal particulates explosion can be controlled through special baghouse design, including baghouse ducting design, and use of explosion detection-suppression systems. Current baghouse explosion detection-suppresston systems which appear suitable for coal baghouses consist of a sensor capable of detecting the initial pressure buildup after coal ignites and a chemfcal extinguishing system capable of suppressing the explosion before tt reaches damaging proportions. The sensor can be either a radiation or pressure type; or, both types can be used together. These sensors and their control units are capable of detecting an explosion and activating an extinguishing system in milliseconds. The suppression system rapidly, by means of explosive discs or bolts, releases a chemical, such as bromochloromethane, which Inhibits combustion reactions. Explosion suppression systems are presently successfully used with baghouses handling dusts similar to pulverized coal such as wood dust.

In addition to use of baghouses for particulate emissions control, extensive use would be made of spray dust suppression systems. These systems, though not shown on the conceptual flow sheets or specified in the equipment lists, would be used at most coal conveyor and feeder transfer points and in the coal breaking area. Each coal dust suppression system would consist of a proportioning-pumping unit, piping, and a series of spray heads. The proportioning-pumping unit provides a water-wetting agent solution to the spray heads at sufficient pressure to cover coal discharged at transfer points with a fine, mist-blanket. Wetting agent is added to dust spray water in order to lower its surface tension from 65 dynes/cm to less than 25 dynes $/ \mathrm{cm}$. Th1s results in a solution which has increased 
wetting, penetrating, and spreading properties. It is more effective in contacting, confining, and agglomerating the micron sized dust than water alone. Actual design of individual spray systems depends on their location, the quantity of dust to be suppressed, and whether or not they are used in combination with other dust control equipment.

\subsection{COAL CLEANING CONCEPTUAL FLOW SHEETS}

Three conceptual flow sheets and major equipment lists were developed for coal cleaning. One set provides for both coarse and fine coal cleaning. The other two represent alternative methods for fine coal cleaning. Material balances for these flow sheets are based on the Pittsburgh Seam coal washability data presented in Table 4-6 and Figure 4-3 in Subsection 4.2. This washability data is very similar to that developed for Kenturky No, 9 Seam coal. And, as a result, the materlal, balances are also applicable for the Kentucky No. 9 coal.

The coal cleaning operations, coarse plus fine, are designed to clean 21.8 million tons per year of ROM coal to produce 16.5 million tons per year of clean coal. Clean coal is conveyed to live storage-blending or dead storage. Coal cleaning design conditions are presented in Table 4-9.

\section{2 .1 Cuarse Coal Breaking, Cileaning, and Crushing}

Fluw sheet FS-1 priesents the flow scheme and material balance developed for coarse coal breaking, cleaning, and coarse clean coal crushing. It also presents one alternative for fine coal cleaning. The inlct boundary for this flow sheet is at the discharge point (c) of the integrated coul inine complex transport coal receiving facility discharge rnnveynr(s) (seo Figure 4-7, Coal Handling and Preparation Operations Block Flow Diagram). This conveyor(s) delivers coal to the breaking operation at a design flow rate of 4,353 tons per hour, 20 hours per day. 

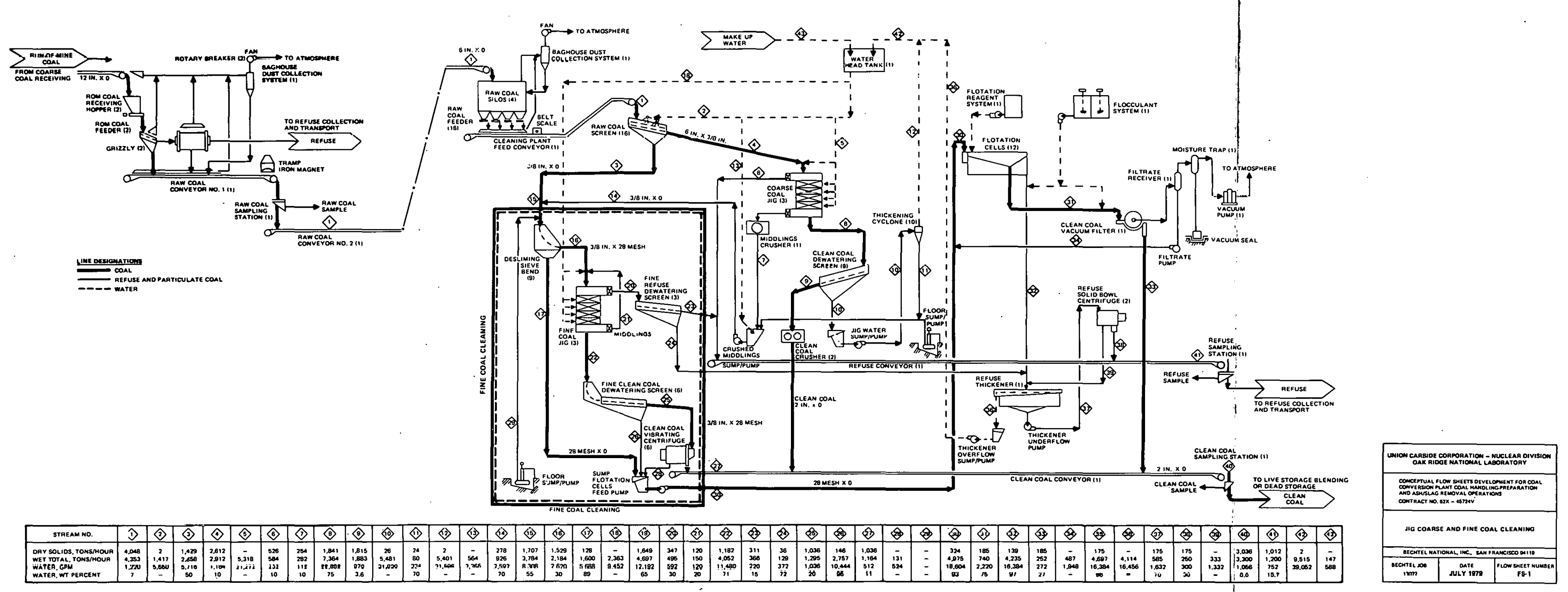
THIS PAGE

WAS INTENTIONALLY

LEFT BLANK 
MAJOR EQUIPMENT LIST

JIG COARSE AND FINE COAL CLEANING

REFERENCE FLOW SHEET FS-1

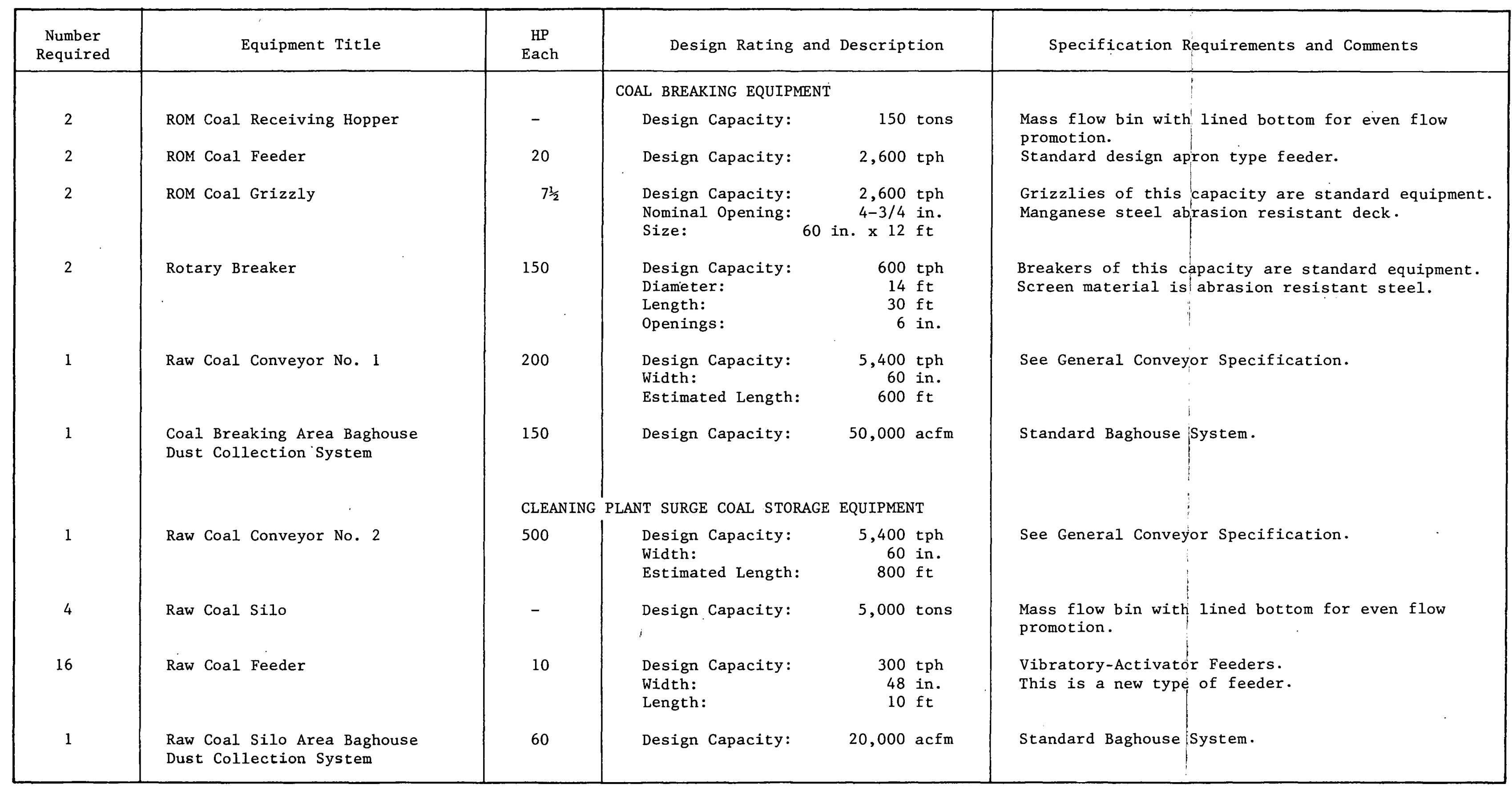




\section{THIS PAGE}

\section{WAS INTENTIONALLY \\ LEFT BLANK}


MAJOR EQUIPMENT LIST

JIG COARSE AND FINE COAL CLEANING

REFERENCE FLOW SHEET FS-1

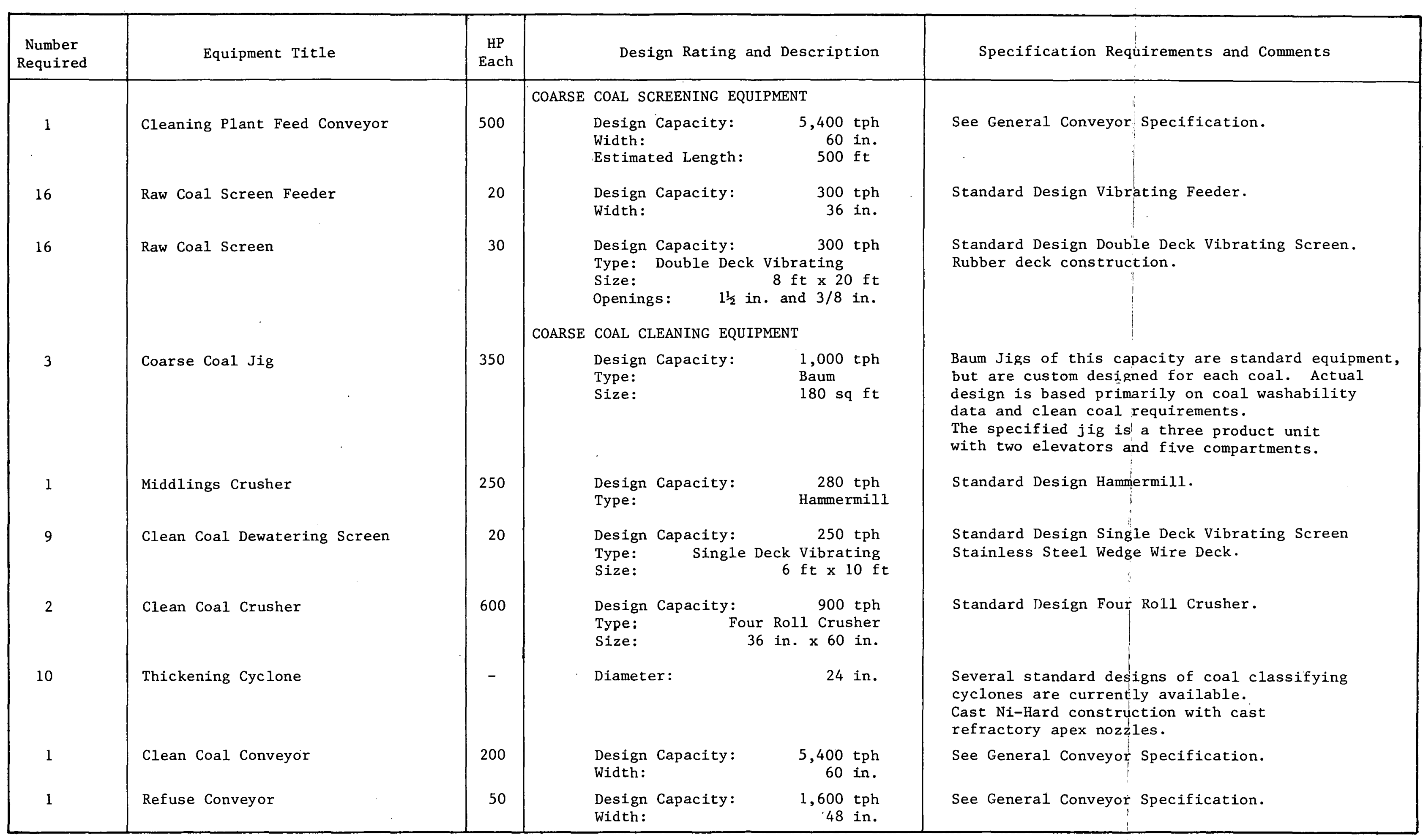




\section{THIS PAGE}

\section{WAS INTENTIONALLY}

LEFT BLANK 


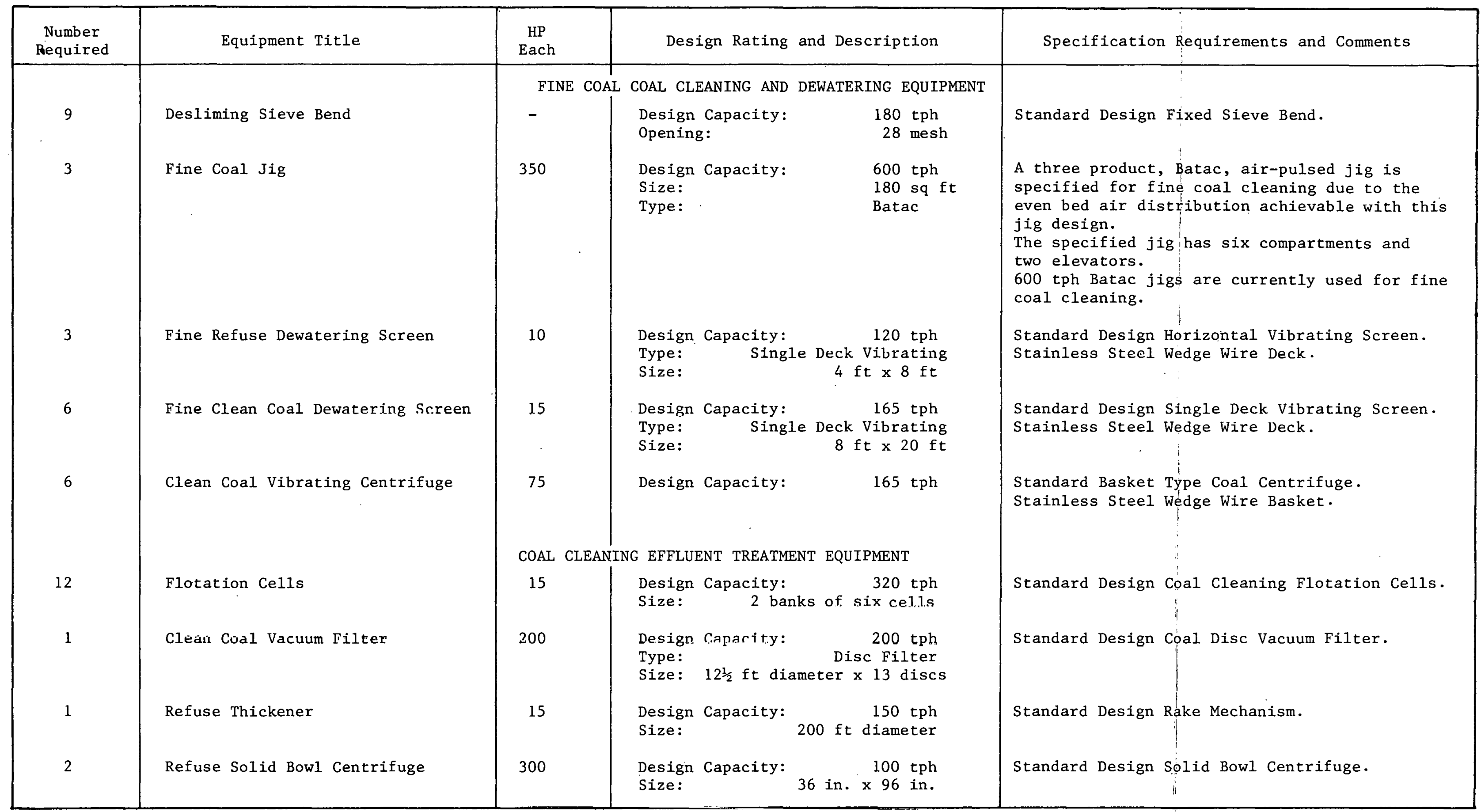




\section{THIS PAGE}

\section{WAS INTENTIONALLY LEFT BLANK}


Coal conveyed to breaking (12 in. $x 0$ ) is discharged into receiving hoppers. From here it is fed by apron feeders onto fixed grizzlies having nominal bar spacings of 4-3/4 inch. Grizzly oversize, nominally plus 6 inch coal falls into a rotary breaker where it is reduced to a top size of 6 inches. Rock and mine debris not crushed are rejected from the breaker. This reject material is discharged to refuse collection and transport.

Coal from the rotary breaker discharges onto a conveyor where it combines with grizzly undersize coal. Broken coal is then conveyed to a sampling station where it is continuously sampled. A flow diagram for a typical coarse coal three stage sampling station is presented in Figure 5- $i$. As coal discharges from raw coal conveyor No. 1 onto conveyor No. 2, a primary sample is cut by a primary sample cutter. This sample is crushed to a top size of $3 / 4$ inch in a hammermill. Crushed primary sample is discharged from a surge hopper onto a belt feeder where it is sampled by a secondary sample cutter. Excess crushed primary sample is diverted to the main coal flow. The secondary sample is crushed to 8 mesh $x 0$ and sampled by a continuous rotary tertiary sampler. The tertiary samples are statistically representative of the entire coarse coal flow and are reasonable quantities for laboratory analysis. To avoid chute plugages during winter operation, the raw coal sample station should be totally enclosed in an insulated and heated building.

Cnal ( $h$ inch $\times 0$ ) is conveyed to a ecrico of four raw coal surge storage silos. These silos at their feed and dishcarge points are equipped with a baghouse coal dust collection system for particulate emissions control. Collected coal from the baghouse system is fed to at least one of the silos. Vibratory-activator feeders located under the raw coal surge storage silos feed coal onto the coal cleaning plant feed conveyor. The feeder discharge points constitute the out let boundary for the cleaning plant surge storage operation identified in Figure 4-7. The boundary.

\section{Preceding page blank $5-17$}




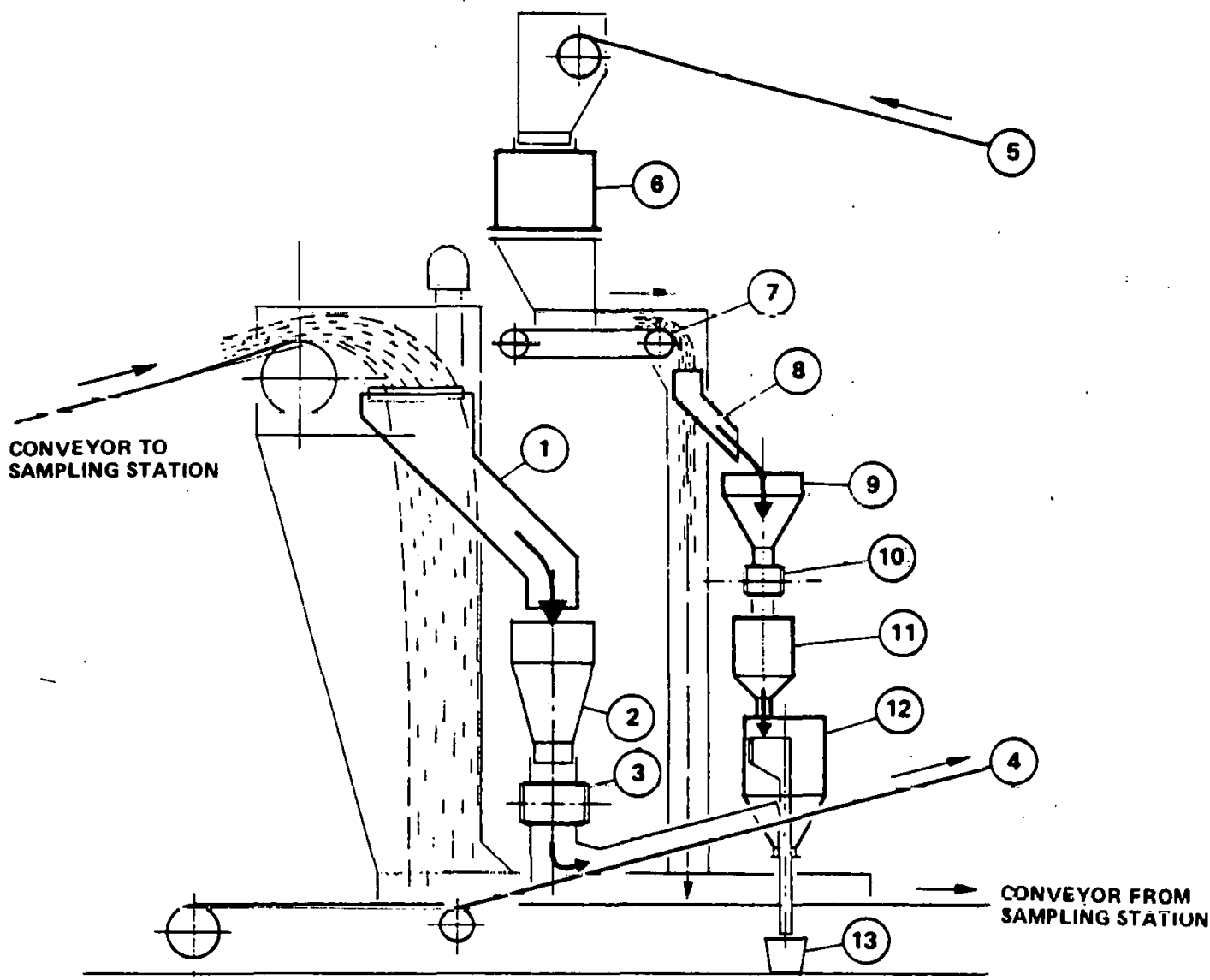

(1) PRIMARY SAMPLE CUTTER

(2) PRIMARY SAMPLE COLLECTING HOPPER

(3) PRIMARY SAMPLE BELT FEEDER

(4) SAMPLE ELEVATING SCISSORS CONV. NO. 1

(5) SAMPLE ELEVATING SCISSORS CONV

(B) PRIMAAY SAMPLE CRUSHER

(7) SECONDARY SAMPLE BELT FEEEER

(B) SECONDARY SAMPLE CUTTER
(9) SECONDARY SAMPLE COLLECTING HOPPER

(10) TERTIARY SAMPLE BELT FEEDER

(11) SECONDARY SAMPLE CRUSHER

(12) TERTIARY SAMPLER

(13) SAMPLE COLLECTIMG BOX 
between this operation and the preceding breaking operation is at the raw coal sampling, station. As indicated in Figure 4-7, an alternative raw coal surge storage method to use of silos is use of an open stockpile.

From raw coal surge storage coal is conveyed and distributed to a series of 16 parallel raw coal screens. The feed conveyor is equipped with a belt scale to measure the quantity of coal fed to the cleaning plant and to provide a signal for control of the raw coal screening operation. Wet vibrating screens are used to split cleaning plant feed coal into coarse and fine fractions for separate cleaning. Screening is performed at $3 / 8$ inch using double-deck screens to reduce screen wear and to obtain.high screening efficiency. Top screen deck aperture is $1-1 / 2$ inch and the bottom $3 / 8$ inch. One and one-third gpm of water is applied to the screens for each ton/hour of coal feed. Screening oversize, 6 inch $x 3 / 8$ inch, flows by gravity to coarse coal cleaning. Undersize, at 50 wt percent solids and $3 / 8$.inch $\times 0$, reports to a fine coal cleaning operation.

Only. one method was considered for coarse coal cleaning; jigging followed by clean coal screen dewatering. Consideration of the other general method used commercially for coarse coal cleaning, heavy-medium cleaning, was not part of project scope (see Subsection 4.2.5). An automatic, two-compartment Baum-type $j i g$ is specified for coarse coal cleaning. This $j i g$ produces three products: clean coal, middlings, and refuse. Middlings and refuse are removed from the $j i g$ by bucket elevators and do not require additional dewatering. Refuse is discharged onto:a refuse conveyor. Middlings are crushed with a hannermill crusher to $3 / 8$ inch top size, slurried in water, and pumped to the fine coal cleaning operation.

clean coal from the coarse coal jigs is dewatered on vibrating screens. Screen oversize is crushed to 2 -inch top size in roll crushers and discharged onto a clean coal conveyor. Undersize from the clean coal dewatering screens, $1 / 4$ inch $\times 0$, are fines created in the $j$ igs or misplaced in the initial raw coal screening operation. These fines are 
pumped to thickening cyclones. Overflow water from these cyclones is directly reused. Cyclone underflow is cumbined with crushed middlings for cleaning in the fine coal cleaning operation.

The clean coal conveyor collects both coarse and fine clean coal and conveys it to live storage-blending or dead storage. As clean coal discharges from this conveynr, it is sampled in a sampling station identical to that described for rat rnal sampling.

With one exception, all equipment specified in the FS-1 major equipment list for coal breaking, surge storage, coarse coal screening, and coarse cual cleaning are of standard design and are widely used commercially for coal. cleaning. The vibratory-activator feeders specified for the raw coal silos are relatively new, but do not require further development. These feeders represent an improvement over existing vibrating feeders for feeding large quantities of coarse coal.

\subsubsection{Fine Coal Cleaning and Dewatering}

Conceptrial flow sheets and major equipment lists were developed for three fine coal cleaning alternatives. These are: jig fine coal cleaning Flow Sheet FS-1; hydrocyclone fine coal cleaning - Flow Sheet FS-1-1; and, tahle fine coal cleaning - Flow sheet FS-1-2. All three flow sheets provide for fine rlean coal dewatering.

The fine coal cleaning circuit presented in FS-1, like the coarse cleaning circuit, uses a jig, but of differenl design from that used for coarse coal cleaning. Before cleaning, however, flue coal ( $3 / 3$ Inch $x 0$ ) is deslimed at 28 mesh with sieve bends. Desliming permits control of the quantity of water introduced to the fine cleaning operation. 


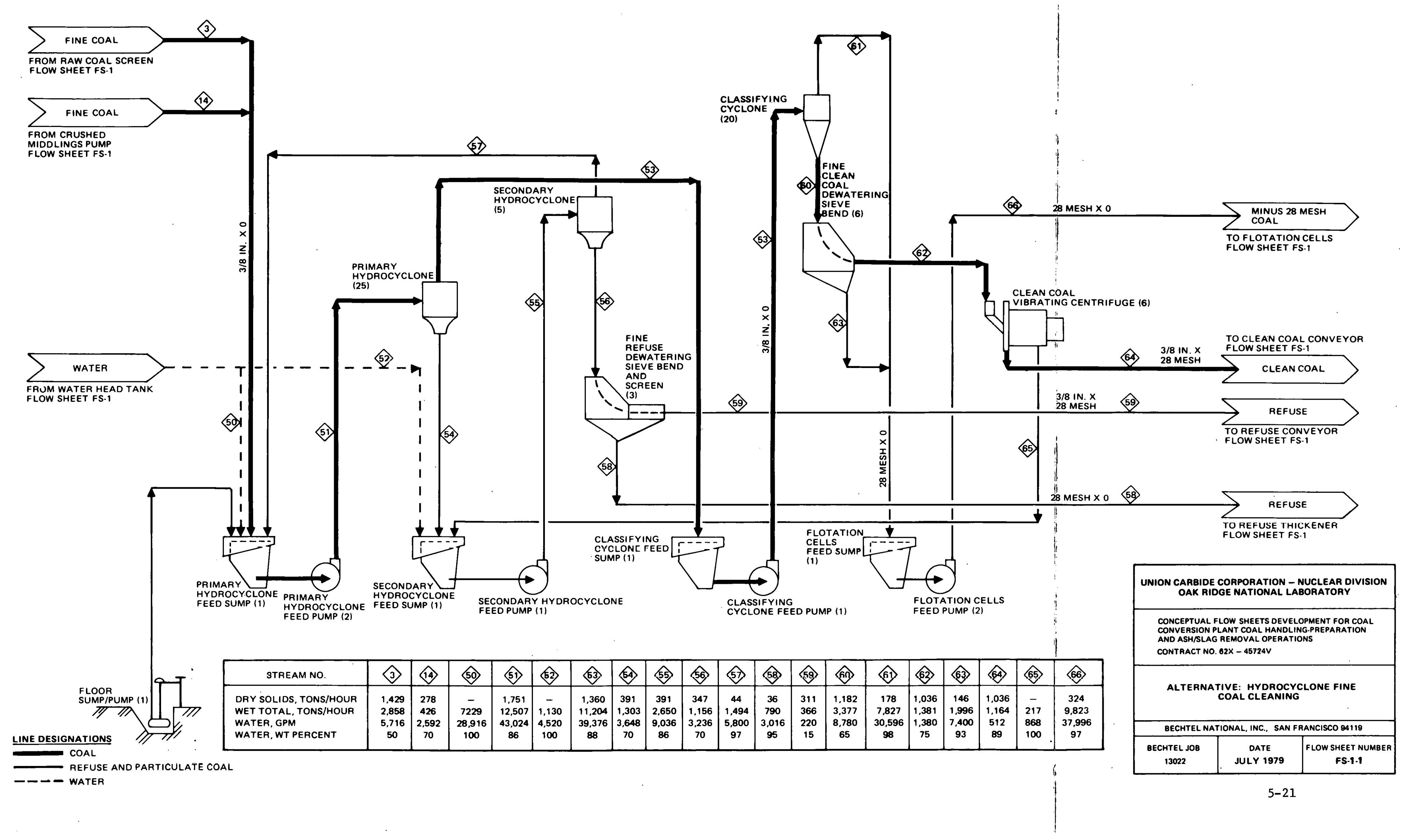


THIS PAGE

WAS INTENTIONALLY

LEFT BLANK 
MAJOR EQUIPMENT LIST

HYDROCYCLONE FINE COAL CLEANING

ALTERNATIVE FLOW SHEET FS-1-1

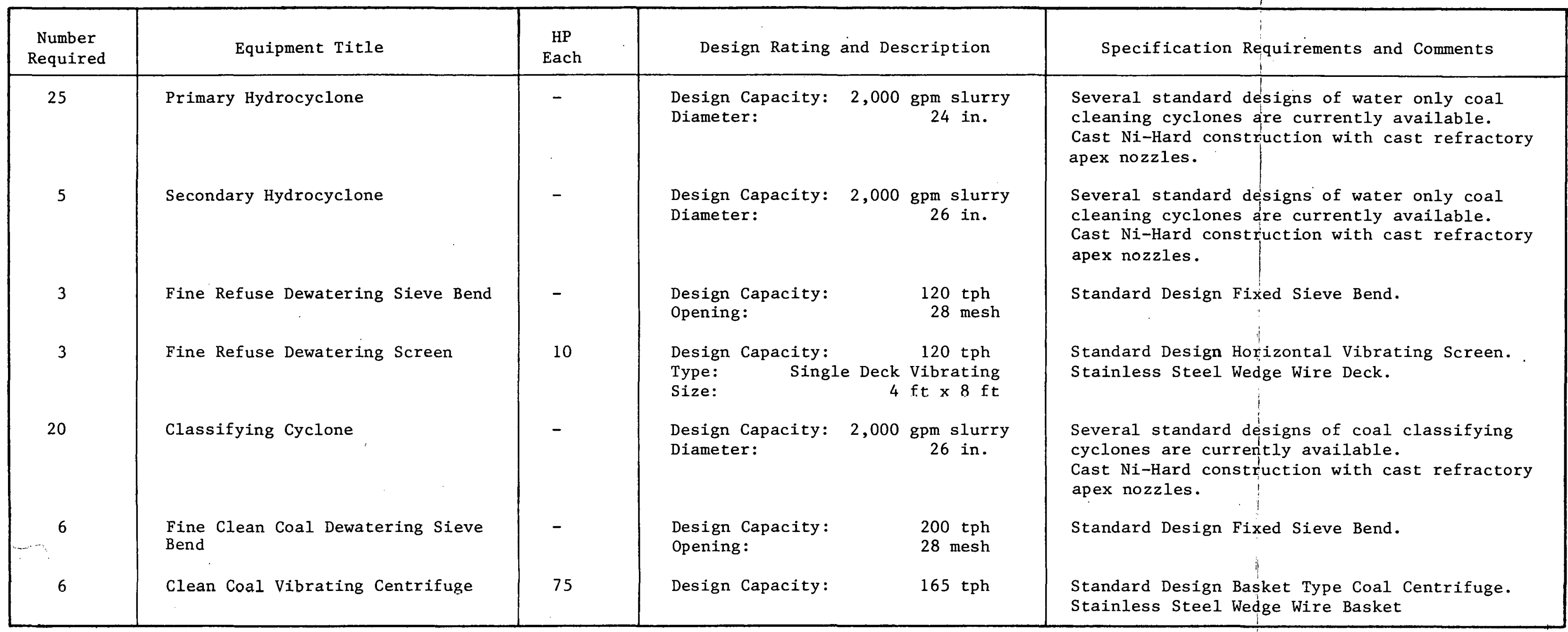


THIS PAGE

WAS INTENTIONALLY

LEFT BLANK 


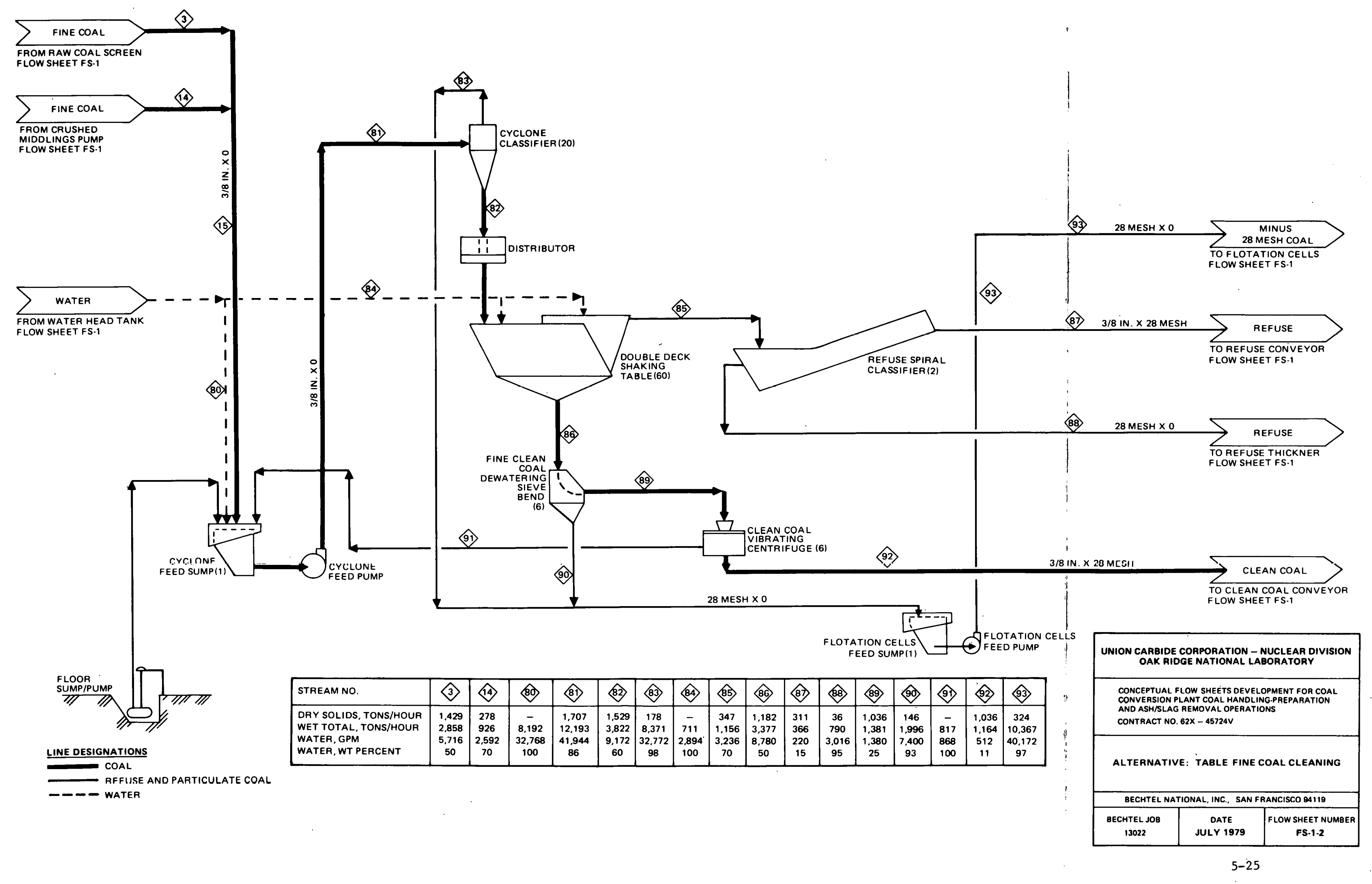


THIS PAGE

WAS INTENTIONALLY

LEFT BLANK 


\begin{tabular}{|c|c|c|c|c|}
\hline $\begin{array}{l}\text { Number } \\
\text { Required }\end{array}$ & Equipment Title & $\begin{array}{c}\mathrm{HP} \\
\text { Each }\end{array}$ & Design Rating and Description & Specification Requirements and Comments \\
\hline 20 & Cyclone Classifier & - & $\begin{array}{l}\text { Design Capacity: } 2,000 \mathrm{gpm} \text { slurry } \\
\text { Diameter: } \\
26 \text { in. }\end{array}$ & $\begin{array}{l}\text { Several standard designs of coal classifying } \\
\text { cyclones are currently available. } \\
\text { Cast Ni-Hard construction with cast refractory } \\
\text { apex nozzles. }\end{array}$ \\
\hline 60 & Shaking Table & 3 & $\begin{array}{lrr}\text { Design Capacity: } & 25 \text { tph } \\
\text { Type: } & \text { Suspended Double Deck }\end{array}$ & $\begin{array}{l}\text { This table is the largest capacity table that } \\
\text { can presently be built due to feeding limitations. } \\
\text { Rubber Deck Construction. }\end{array}$ \\
\hline 2 & Refuse Spiral Classifier & 15 & $\begin{array}{lc}\text { Design Capacity: } & 160 \mathrm{tph} \\
\text { Type: } & \text { Spiral } \\
\text { Spiral Diameter: } & 84 \text { in. }\end{array}$ & Standard Design Spiral Classifier. \\
\hline 6 & $\begin{array}{l}\text { Fine Clean Coal Dewatering Sieve } \\
\text { Bend }\end{array}$ & - & $\begin{array}{l}\text { Design Capacity: } \\
\text { Opening: }\end{array}$ & Standard Design Fixed Sieve Bend. \\
\hline 6 & Clean Coal Vibrating Centrifuge & 75 & Design Capacity: & $\begin{array}{l}\text { Standard Design Basket Type Coal Centrifuge. } \\
\text { Stainless Steel Wẹdge Wire Basket. }\end{array}$ \\
\hline
\end{tabular}


THIS PAGE

\section{WAS INTENTIONALLY \\ LEFT BLANK}


Jig fine coal cleaning is accomplished with three parallel, Batac-type jigs. The specified jigs are each designed to clean 600 tons per hour of coal. These air-pulsed jigs allow even, regular pulsing of the entire jig width which results in improved bed stratification compared with a Baumtype jig. Each jig has six air pulse compartments and two bucket elevators; one elevator fór middlings and one for refuse. Clean fine coal overflows at the jig ends. Middlings, which are mainly misplaced material, are recycled directly to the jig feed. Refuse, partially dewatered by the refuse elevators; is further dewatered on 28 mesh opening, singledeck, vibrating screens. Oversize refuse discharges to the refuse conveyor. Undersize refuse flows to an effluent treatment operation.

Clean coal overflowing the fine coal jigs is dewatered to 15-20 wt percent total moisture on 28 mesh opening, single-deck vibrating dewatering screens. Oversize from these screens, $3 / 8$ inch $\times 28$ mesh clean coal, is further dewatered to approximately 11 wt percent total moisture with vibrating basket centrifuges. Dewatered coal is discharged to the clean coal conveyor where it combines with crushed, clean coal from the coarse coal cleaning operation. Water removed by the dewatering screens and centrate is pumped to effluent treatment.

Flow Sheet FS-1-1 presents the hydrocycloning fine coal cleaning alternative. Fine coal from the raw coal screens plus coarse coal cleaning operation crushed middlings and thickened clean coal dewatering fines are initially combined in a sump. Sufficient make-up and hydrocyclone circuit recycle water is added to this sump to produce a coal slurry containing approximately 14 wt percent coal. This slurry is pumped into 25 parallel primary hydrocyclones. Underflow from these hydrocyclones is diluted with water and recleaned in 5 parallel secondary hydrocyclones. Underflow from these hydrocyclones is refuse. Overflow from the secondary hydrocyclones is recycled to the primary hydrocyclone feed sump. 
Fine refuse resulting from hydrocycloning. is dewatered on sieve bends in combination with single-deck vibrating screens. Oversize refuse is discharged onto the refuse conveyor (see FS-1). Undersize refuse, minus 28 mesh, flows to an effluent treatment operation.

Overflow from the primary hydrocyclones, which contains clean fine coal, is classified at 28 mesh in 20 parallel classifying cyclones. A minus 28 mesh coal fraction is classified into the cyclone overflow and a $3 / 8$ inch $x$ 28 mesh fraction is obtained in the underflow. Underflow is dewatered on parallel sieve bends. Sieve bend oversize, $3 / 8$ inch $\times 28$ mesh, is further dewatered to approximately 11 wt percent total moisture in 6 , parallel, vibrating basket centrifuges. Cake from the centrifuges is discharged to the clean coal conveyor (see FS-1) where it combines with crushed, clean coal from the coarse coal cleaning operation. Centrate flows to the secondary hydrocyclone feed sump for recovery of any misplaced coal. Overflow from the classifying cyclones is combined with dewatering sieve bend underflow in a sump. From here it is pumped to an effluent treatment operation.

FS-1-2 presents the table fine coal cleaning alternative. As in FS-1-1, fine coal" trom the raw coal screens plus coarse coal cleaning operation crushed middlings and thickened clean coal dewatering fines are combined in a sump. Sutticient water is added to this sump to produce a $1.4 \mathrm{wt}$ percent coal slurry. This slurry is pumped into 20, parallel classifying cyclones for desliming at 28 mesh. The overflow slimes are collected in a sump and then pumped to an effluent treatment operation.

Deslimed fine coal, $3 / 8$ inch $\times 28$ mesh, is distrihuted to 60, parallel, double-deck shaking tables for cleaning. A large number of tables are required because of table design limitations. As far as known, the tables specified are the largest in use for coal cleaning. olean coal overflows the table sides opposite the feed points into launders 
which transport it to 6 , parallel, dewatering sieve bends. Sieve bend oversize, $3 / 8$ inch $\times 28$ mesh, is further dewatered in six parallel, vibrating, basket centrifuges. Cake from the centrifuges is discharged to the clean coal conveyor (see FS-1) where it combines with crushed clean coal from the coarse coal cleaning operation. Centrate flows to the cyclone feed sump for recovery of any misplaced coal.

Undersize from the clean coal dewatering sieve bends, minus 28 mesh coal, flows to the same sump as the cyclone classifier overflow. From here it is pumped to an effluent treatement operation.

Refuse overflows the tables into launders which transport it to spiral classifiers. Refuse from these classifiers is discharged to the refuse conveyor (see FS-1). Spiral classifier overflow flows to an effluent treatment operation.

Like equipment specified for coarse coal cleaning, equipment for all three fine coal cleaning alternatives is of standard design and is widely used commercialiy for coal cleaning. Of the three alternatives, all can produce clean coal of nearly equal quality and at comparable recoveries. Total operating cost, including appropiriate capital charges, would be the main factor in selecting a best alternative.

Considering the quantities of equipment required, jig fine coal cleaning is probably the least complicated of the three alternatives. For an actual coal conversion plant, heavy-medium fine coal cleaning would be considered, as well as, the three alternatives for which flow sheets were developed.

\subsubsection{Coal Cleaning Effluent Treatment}

Future coal cleaning plants may require closed loop water systems without ponds. Effluent emission regulations may not allow release of any polluted water from such plants. As a result, effluent treatment will be an important operation in all future coal cleaning plants. 
FS-1, in addition to presenting flow schemes for coarse coal cleaning and one fine coal cleaning alternative, presents a conceptual flow sheet for one cleaning plant effluent treatment approach. This treatment operation recovers water for reuse and clean coal. Feed to the effluent treatment operation is produced by all three fine coal cleaning flow sheets and consists of: slimes (minus 28 mesh raw coal), fine clean coal dewatering underflow, and minus 28 mesh refuse. The slimes and clean coal dewatering underflow are pumped to froth flotation cells for coal recovery. Minus 28 mesh refuse is sent to a refuse thickener.

Float coal from the flotation cells, clean 28 mesh $x 0$ coal, is dewatered on a disc vacuum filter. Filter cake is conveyed to the cleaning plant clean coal conveyor where it combines with clean coal from the coarse and fine cleaning operations. Filtrate is recycled directly to the flotation cells.

Flotation refuse is pumped to a refuse thickener. Together with the other minus 28 mesh solids from fine coal cleaning, it is thickened with the aid of a flocculant. Underflow from this thickener is dewatered to approximately 30 wt percent moisture in solid bowl centrifuges. Centrifuge cake discharges onto the refuse conveyor. Centrate and refuse thickener overflow are pumped to the cleaning plant head tank for reuse.

Froth flotation is only one of many methods that could conceivably be part of a system to recover coal and produce recyclable water from cleaning plant effluents. However, it is the most common approach currently used when any coal. cleaning plant effluent. treatment is provided. Other possible techu nologies that might be used are indicated in Figure 4-7. Metermination of the best effluent treatment approach for use in commercial coal conversion plant cleaning operations will depend on economics, applicable plant effluent emission regulations, coal cleaning plant design, raw coal characteristics, and refuse disposal considerations. 


\subsection{COAL STORAGE AND BLENDING CONCEPTUAL FLOW SHEETS}

Two basic types of large-capacity coal storage will likely be required for coal conversion: live storage with or without blending and dead storage. As discussed in Subsection 4.3.2, 1ive storage design capacity was established at 500,000 tons and dead storage is intended for emergency use only. However, differentiation between what constitutes live and dead storage for some storage configurations is difficult. As a result, both basic types of storage are discussed together.

As discussed in Section 4, the need for blending and the degree required has yet to be quantified for any of the nine coal conversion processes considered. Process information required to determine the cost savings, if any, that might be realized for converting blended versus unblended coal has yet to be developed. Once this information is available, these savings can be compared with the cost for different coal blending levels. Three general blending levels can be considered for coal conversion: simple, intermediate, and full.

Table 5-1 and Figures 5-2 and 5-3 present major alternatives for largescale, high-capacity coarse coal storage. The three general blending levels and equipment required to achieve them are also presented. Two general storage alternatives are identified: open stockpile storage and enclosed storage.

For a given storage capacity, open stockpiles are inevitably less expensive than enclosed storage. A primary reason for considering enclosed storage for commercial coal conversion plants is fugitive particulates emissions. Current coal open stockpile fugitive particulates emission regulations are vague. However, in the future, particularly when the time frame for construction of commercial coal conversion plants is considered, they are liable to become more precise and stringent. Further, current methods used to control open stockpile fugitive emissions appear to be both expensive and 
limited to their ability to achieve significantly lower particulate emissions. If future permitted fugitive particulate emissions are significantly lower than those specified by current regulations, totally-enclosed live storage facilities and possibly new dead storage facility designs will likely be required. This could be particularly true for storage facilities as large, both in the quantities of coal handled and area required, as those judged required for commercial coal conversion plants. In addition to allowing better fugitive particulates control, use of enclosed storage in locations where long or severe winter conditions exist, would reduce problems associated with handling of frozen and wet coal.

As Flgure 5-2 indicates. many npen stockpilc configuraliuns are possible. Major factors which influence that best suited for a given situation 1nilude:

- Required coal flow in and out of storage

- Live storage design capacity

- Dead storage design capacity

- Coal handling criteria: contínuous or intermittent

- Blending requirements

- Land availability

- Ecúnumícs

For open stockpile blending, at least two stockpiles are required; one to be reclaimed while the other is built. There are two approachee for buildiug of blending stockpiles: chevron layering and wintrow layering. Simplu blending is achieved when a pile built with a chevron pattern is reclaimed in small sections, such as by a bucket wheel reclaimer. When a chevron stockpile is reclaimed in full cross section, by such equipment as a drun seclalmer, intermedlace blending is achieved. Full blending is achieved when a stockpile built in windrow layers is reclaimed in full 


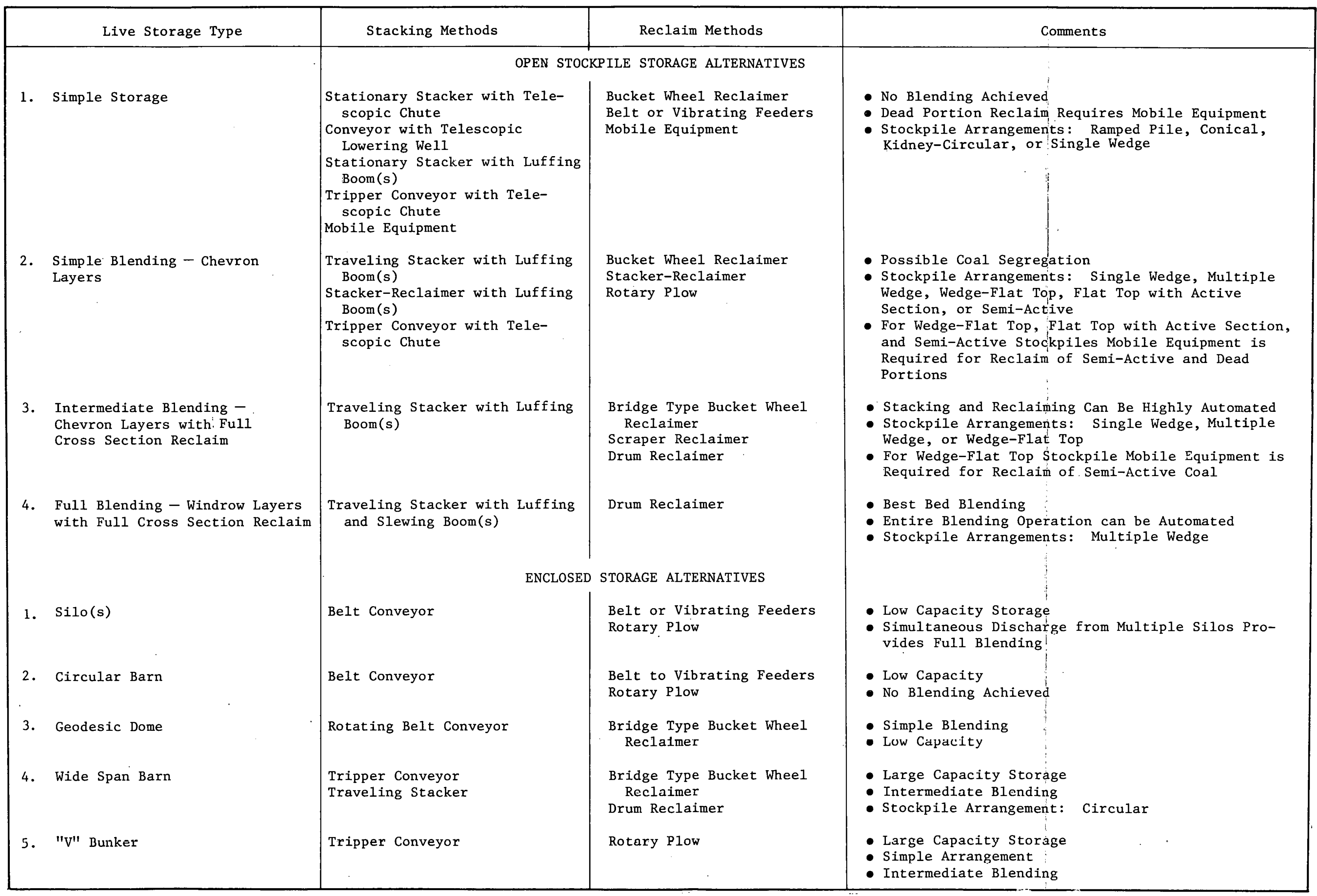

(1) Stockpile arrangements are presented in Figure 5-2 and enclosed storage structures are presented in Figure 5-3. 


\section{THIS PAGE}

\section{WAS INTENTIONALLY LEFT BLANK}




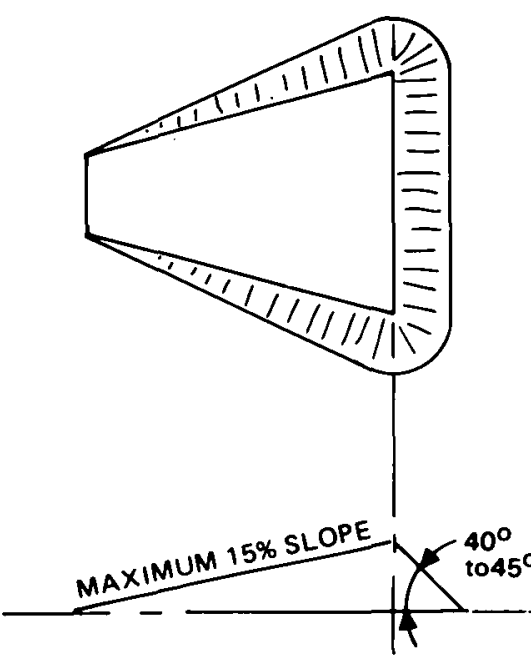

STOCKPILE CONSTRUCTION METHOD MOBILE EQUIPMENT STOCKPILE RECLAIM METHOD $\longrightarrow$ MOBILE EQUIPMENT

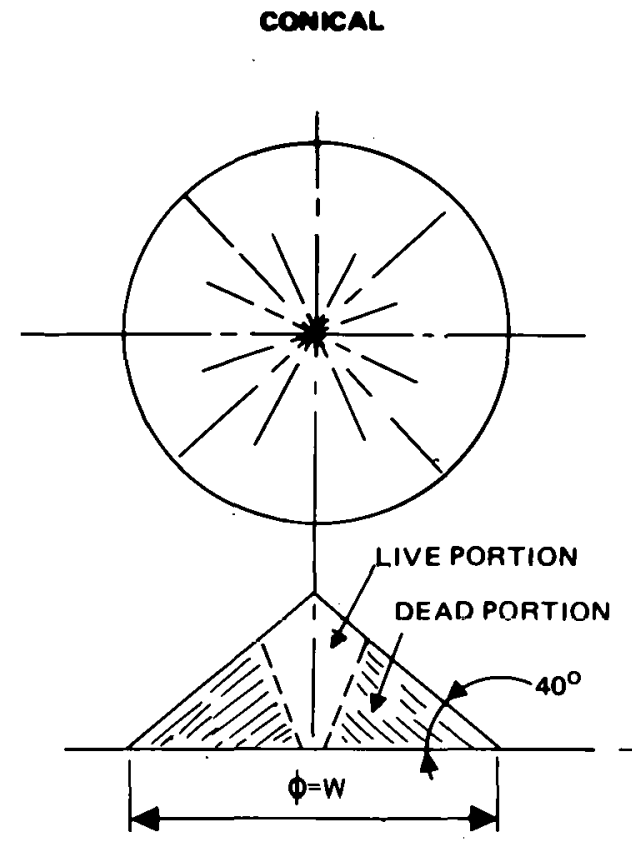
BELT CONVEYOA

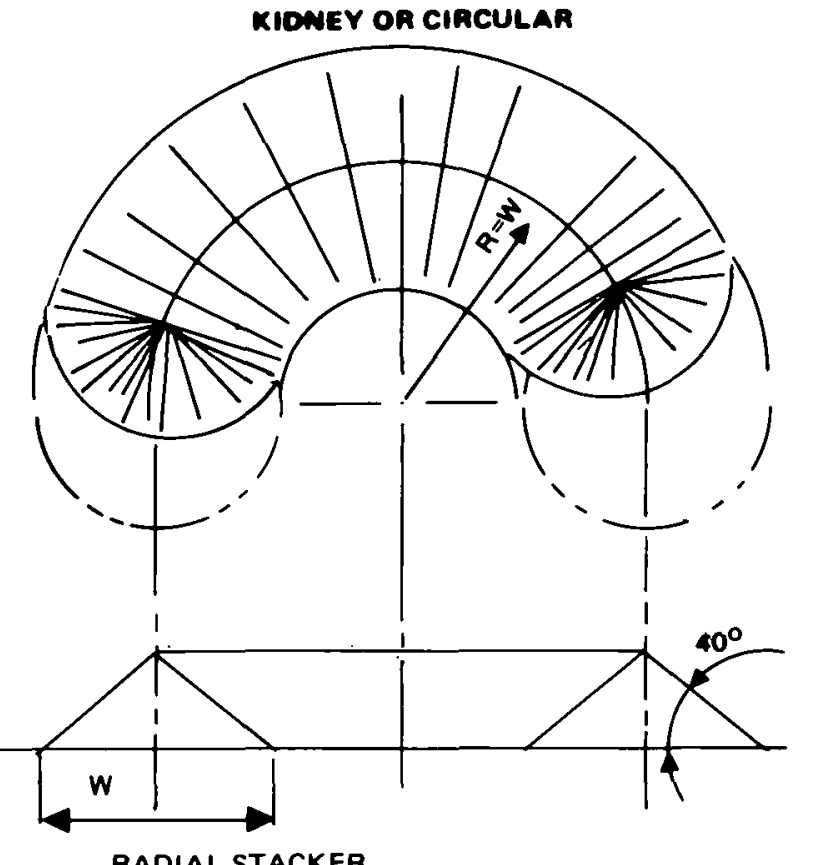

RADIAL STACKER

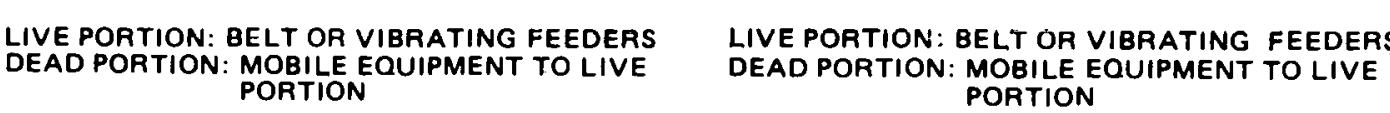

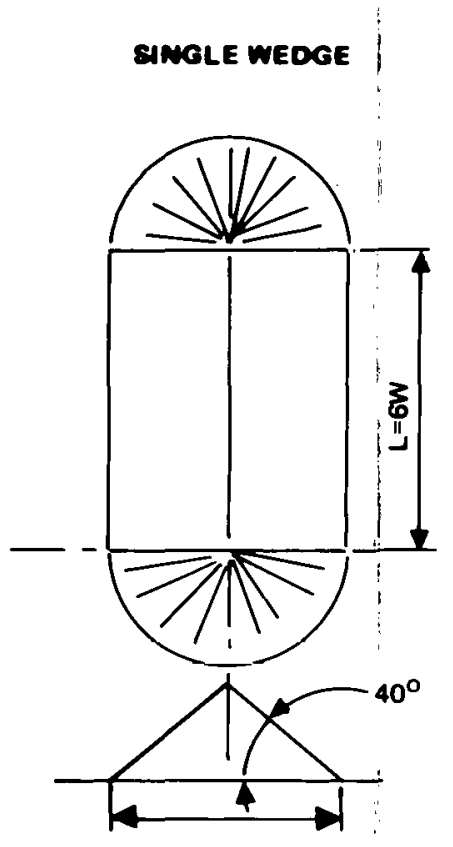

TRAVELING STACKER
STACER-RELAIMER
TRIPPER CONVEYOR

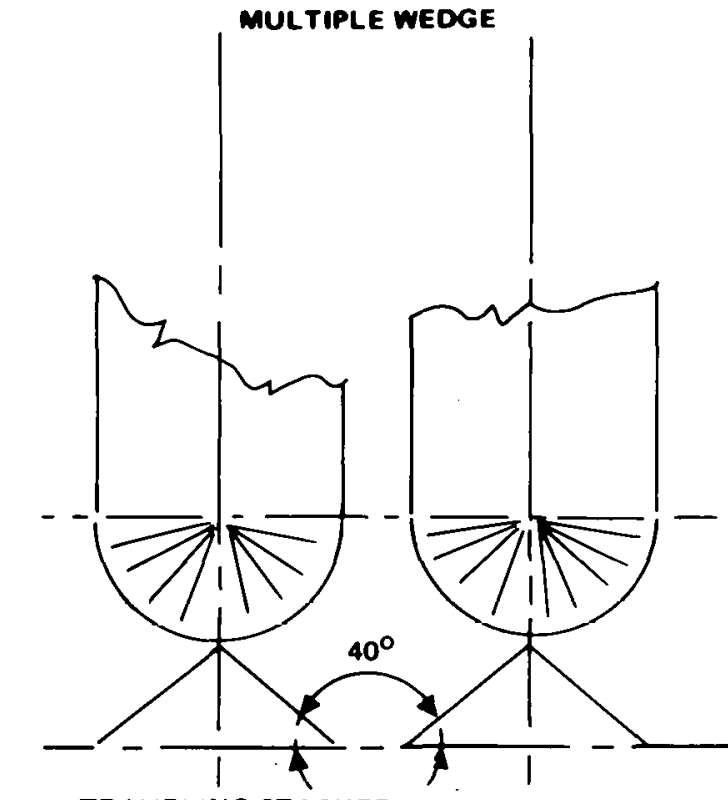
TRAVELING STACKER
STACKER-RECAIMER
TRIPPER-CONVEYOR

STACKER-RECLAIMER , STACKER-RECLAIMER BUCKET WHEEL RECLAIMER
BRIDG TYPE BUCKET WHEEL RECLAIMEA BRIDGE TYPE DRUM RECLAIM
CRAPER RECLAIMER

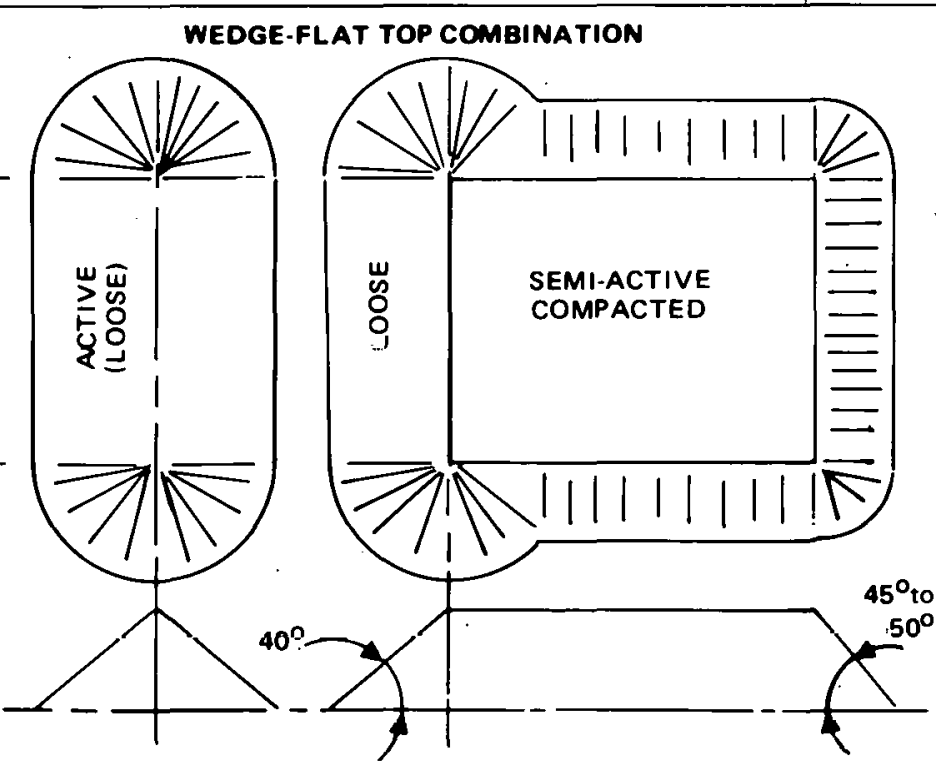

TRAVELING STACKER
STACKER-RECAAIMER MOBILE EQUIPMENT REQUIRED FOR SEMI-ACTIVE PORTION

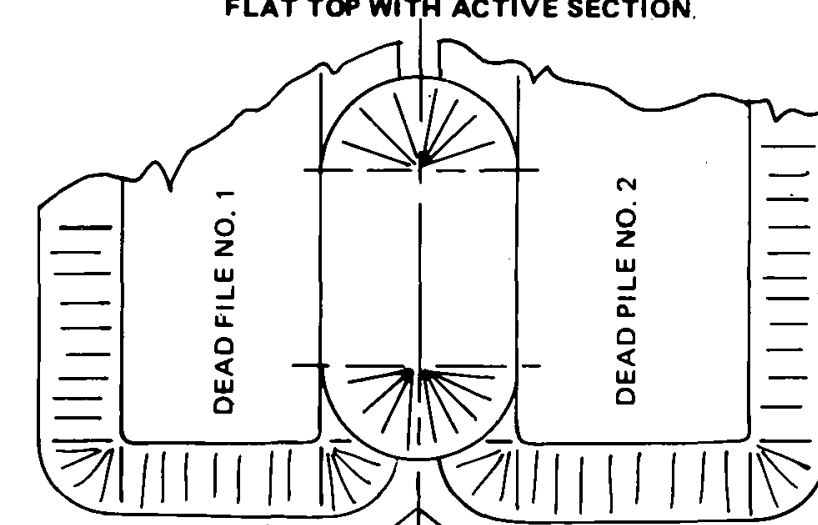

$\begin{array}{r}45^{\circ} \text { to } \\ 5^{50^{\circ}} \\ \hline\end{array}$
STOCKPILE CONSTRUCTION METHOD STOCKPILE RECLAIM METHOD $\longrightarrow$
STACKER-RECLAMER
BUCKET WHEEL RECLAIM

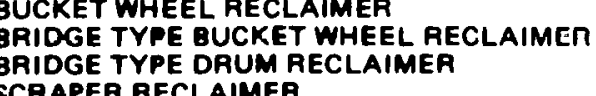

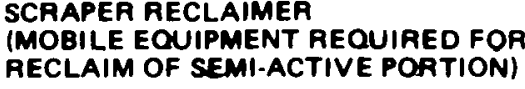
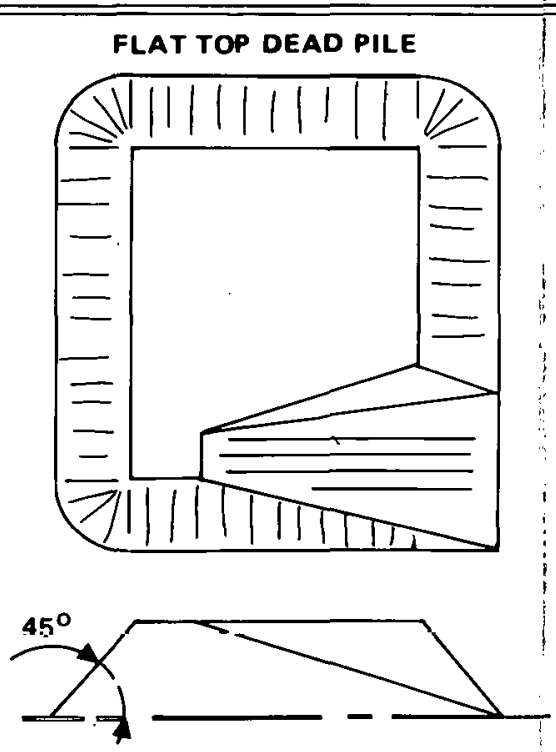

TRAUELING STACKER AND MOBLLE
EOUIPMENT

MOBILE BUCKET WHEEL RECLAIMER

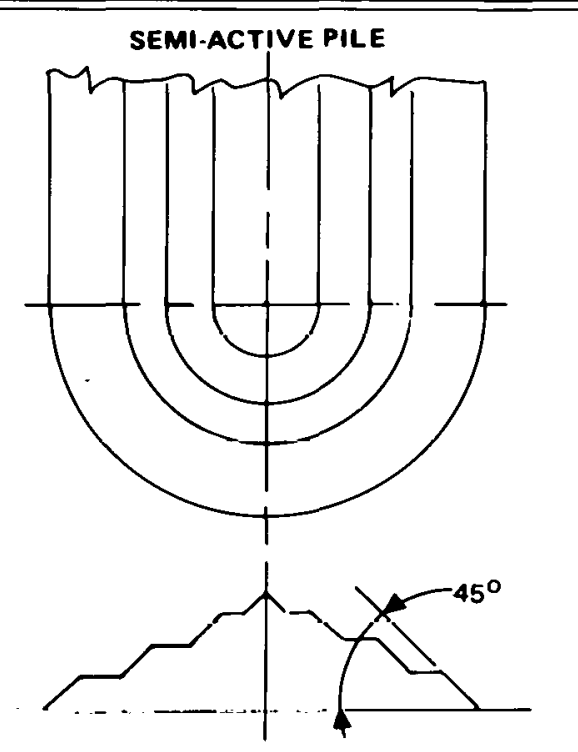

TRAVELING STACKER AND MOBILE
EQUIPMENT TRACK MOUNTED BUCKET WHEEL
RECLAIMER

Figure 5-2 OPEN COAL STOCKPILE ALTERNATIVES 


\section{THIS PAGE}

\section{WAS INTENTIONALLY \\ LEFT BLANK}




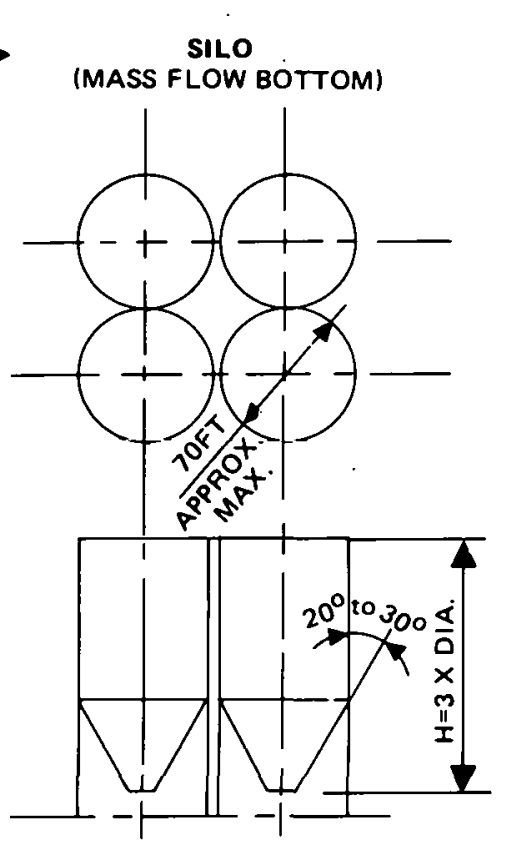

ENCLOSED STORAGE FEED METHOD $\longrightarrow$ BELT CONVEYOR

ENCLOSED STORAGE RECLAIM METHOD $\rightarrow$ BELT OR VIBRATING FEEDERS

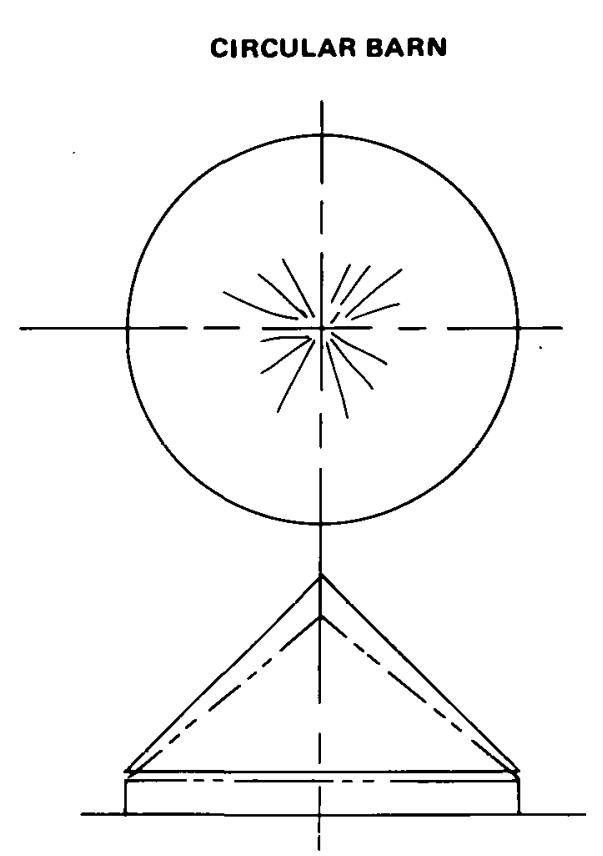

BELT CONVEYOR

BELT OR VIBAATING FEEDERS

ROTARY PLOW
GEODESIC DOME

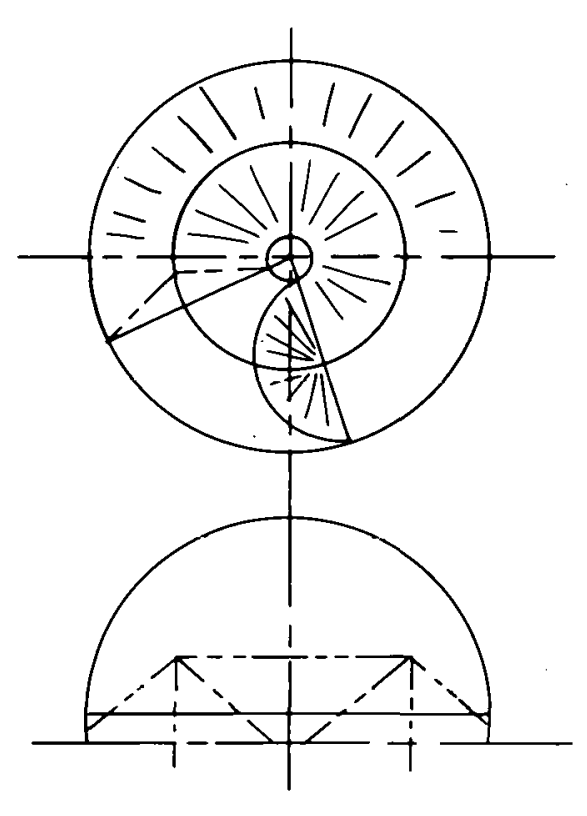

ROTATING BELT CONVEYOR

BRIDGE TYPE BUCKET WHEEL RECLAIMER
WIDE SPAN BARN

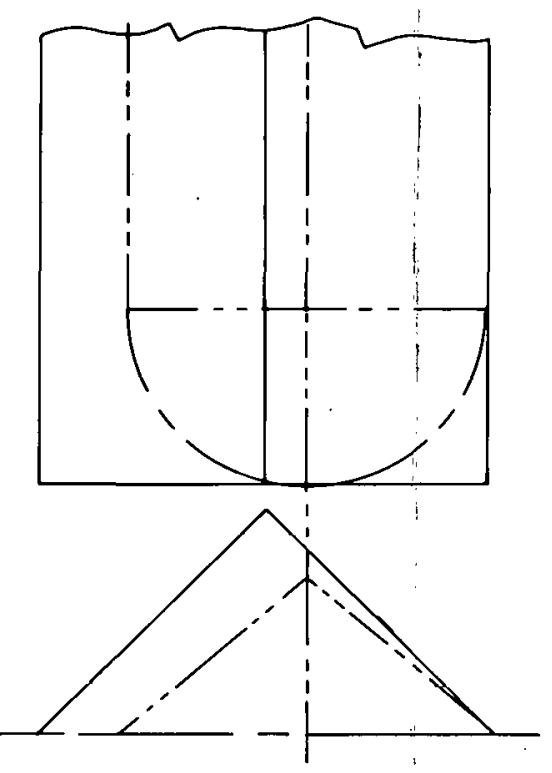

TRAVELING STACKER

IDGE TYPE BUCKET WHEEL RECLAIMEA

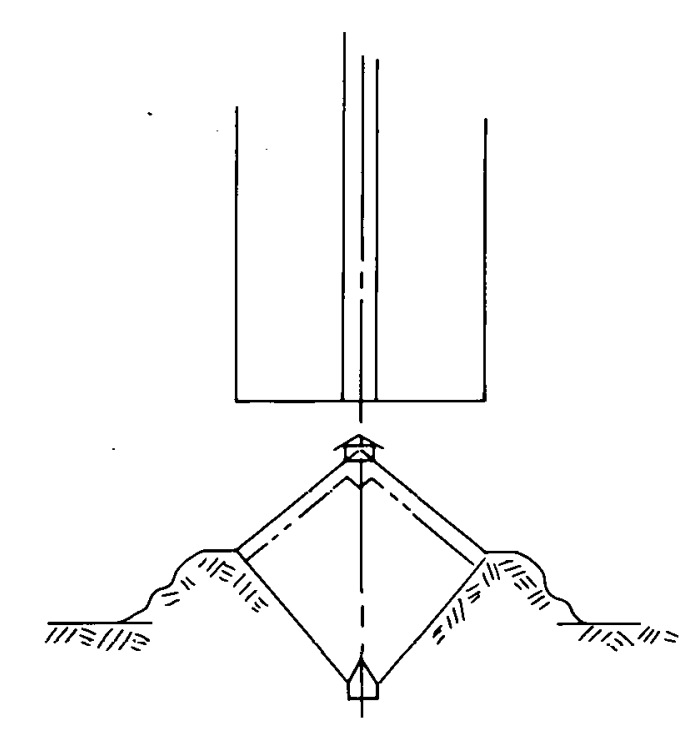

TRIPPER CONVEYOR

Figure 5-3 ENCLOSED COAL STORAGE ALTERNATIVES 


\section{THIS PAGE WAS INTENTIONALLY LEFT BLANK}


cross section. Building of windrow piles is more complicated than chevron piles due to the slewing movement required by the traveling stacker booms. Booms on stackers for windrow layering are also usually longer than those on stackers used to build chevron piles.

Unless future fugitive particulate emission regulations prevent it or the conversion plant is located in an area with severe winters, open stockpiles would most likely be used for live storage. Alșo, it is believed that at least intermediate blending would be justified. No conceptual flow sheet, however, is presented for this type of live storage-blending operation. The open stockpile flow sheet and major equipment list presented in the coal mine-coal conversion plant interface evaluation project final report (1) are believed sufficient for Union Carbide's equipment requirements survey. The interface project open stockpile consists of four, long wedge piles which are built with two traveling stackers and reclaimed in full cross section by two rotary drum reclaimers. Coal design feed rates to and from this live storage-blending facility are slightly larger than those required for the flow sheets presented in this report. The specific interface final report flow sheet showing the live storage-blending facility and drawings of this facility are:

- Live storage-blending facility flow sheet:. PFD-1, (Volume 1)

- Live storage-blending facility plot plan: Drawing D-20 (Volumes 1 and 2)

- Open stockpile live storage facility sections: Drawing D-22 (Volume 2)

- Open stockpile live storage facility major equipment 1ist: Section 10.2 (Volume 2)

A conceptual flow sheet has been developed for enclosed coarse coal live storage-blending. This flow sheet, FS-2-I, is considered as an alternative to multiple wedge open stockpile storage-blending. It consists of three 
V-bunkers. This type of enclosed storage structure and wide span barns are best suited for storage of the extremely large quantities of coal judged to be required for coal conversion. As shown in Figure 5-3, a wide span barn is essentially a covered wedge stockpile. It would use stackers very similar to those used for building open wedge stockpiles. These rail-mounted stackers would move along one barn side only and, hence, would have only a single boom. Bridge-type bucket wheel and drum reclaimers used with wide span barns are identical to those for open stockpiles. Conveyor systems required for wide span barns are very similar to those required for analogous wedge open stockpile facilities. The main deciding factor between use of V-bunkers and wide span barns for large-capacity enclosed live storage-blending is cost.

In addition to three concrete and steel construction V-bunkers (Drawing D-23 in Volume 2 of the coal mine-coal conversion plant interface evaluation final report presents a conceptual design for a typical V-bunker), the V-bunker storage-blending facility consists of the conveying systems required to feed coal to and reclaim it from these bunkers and to divert it to coal conversion or to the steam/power plant. Total combined design live storage capacity for the three identical V-bunkers is 500,000. wet tons; a 10 day supply of conversion plant coal. These bunkers could receive coal from either a cleaning plant or trom a rail and/or barge receiving facility or from dead coal storage.

Coarse coal (2 inch $x$ ) is fed to the V-bunker facility by a 72-inch-wide live storage feed conveyor which terminates at a transfer tower (see flow sheet FS-2-1). Here a flop gate diverts coal to either the No.1 V-bunker or to a 72-inch-wide live storage feed transfer conveyor. The transfer conveyor conveys coal to bunker No.2 or to another transfer conveyor which feeds bunker No.3. One V-bunker is filled while one of the other two is being reclaimed. Tripper conveyor systems, consisting of a conveyor and a mobile tripper car which moves along the conveyor, are used to 


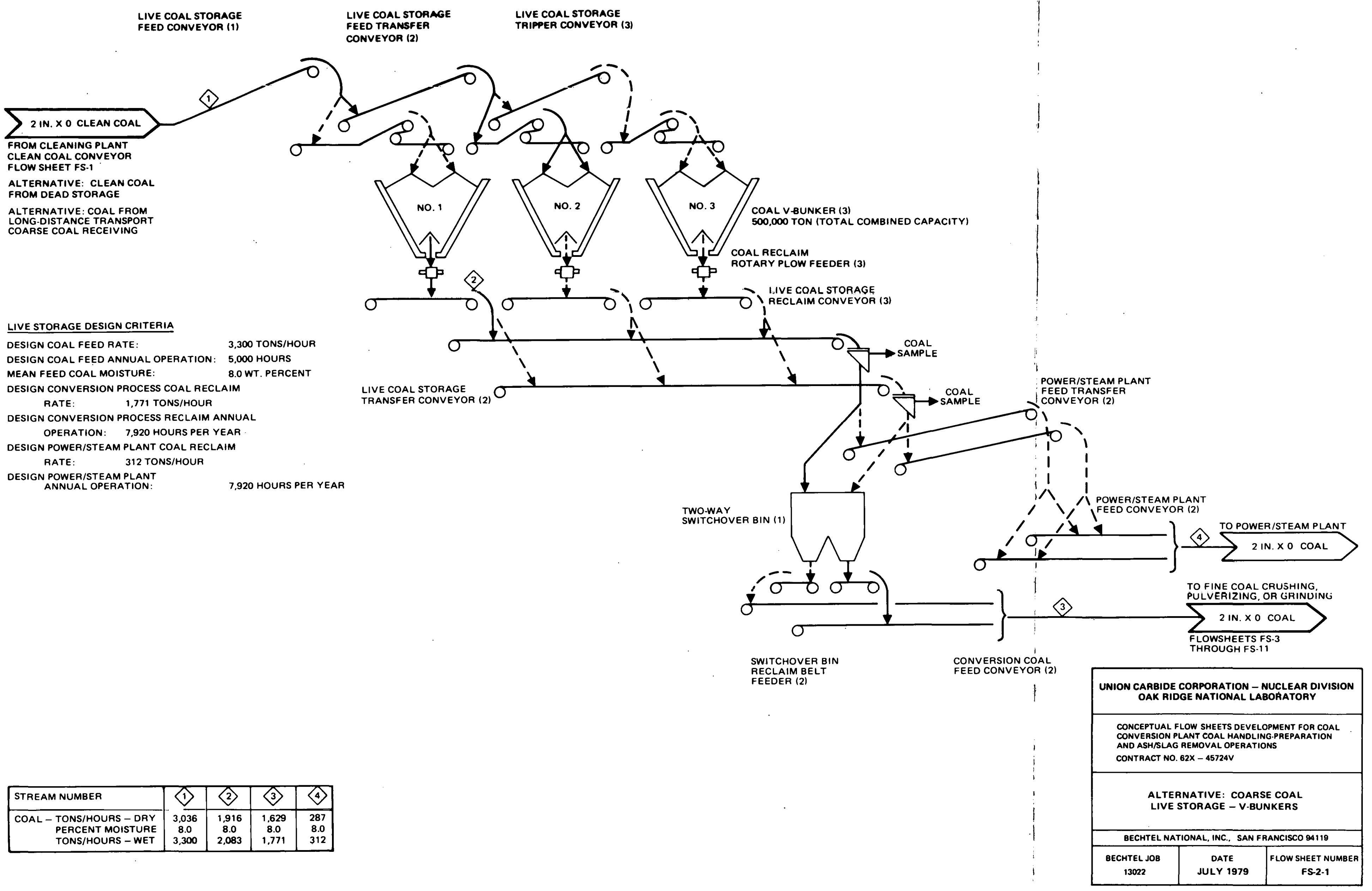


THIS PAGE

WAS INTENTIONALLY

LEFT BLANK 
MAJÓR EQUIPMENT LIST

COARSE COAL LIVE STORAGE-V-BUNKERS ALTERNATIVE FLOW SHEET FS-2-1

\begin{tabular}{|c|c|c|c|c|}
\hline $\begin{array}{c}\text { Number } \\
\text { Required }\end{array}$ & Equipment Title & $\begin{array}{c}\mathrm{HP} \\
\text { Each }\end{array}$ & Design Rating and Description & Specification Requirements and Comments \\
\hline 1 & Live Coal Storage Feed Conveyor & 750 & $\begin{array}{l}\text { Design Capacity: } \\
\text { Belt Width: }\end{array}$ & See General Conveyọr Specification. \\
\hline 2 & $\begin{array}{l}\text { Live Coal Storage Feed Transfer } \\
\text { Conveyor }\end{array}$ & 250 & $\begin{array}{l}\text { Design Capacity: } \\
\text { Belt Width: }\end{array}$ & See General Conveyor Specification. \\
\hline 3 & Live Coal Storage Tripper Conveyor & 500 & $\begin{array}{l}\text { Design Capacity: } \\
\text { Belt Width: }\end{array}$ & See General Conveyor Specification. \\
\hline 3 & Coal Reclaim Rotary Plow Feeder & 30 & Design Capacity: & $\begin{array}{l}\text { Rotary plow feeders of this capacity are avail- } \\
\text { able as standard equipment. }\end{array}$ \\
\hline 3 & Live Storage Reclaim Conveyor & 150 & $\begin{array}{l}\text { Design Capacity: } \\
\text { Belt Width: }\end{array}$ & See General Conveyor Specification. \\
\hline 2 & Live Coal Storage Transfer Conveyor & 200 & $\begin{array}{l}\text { Design Capacity: } \\
\text { Belt Width: }\end{array}$ & See General Conveyor Specification. \\
\hline 2 & $\begin{array}{l}\text { Power/Steam Plant Feed Transfer } \\
\text { Conveyor }\end{array}$ & 75 & $\begin{array}{l}\text { Design Capacity: } \\
\text { Belt Width: }\end{array}$ & See General Conveyor Specification. \\
\hline 1 & Two-Way Switchover Bin & - & Dimensions: $30 \mathrm{ft} \times 15 \mathrm{ft} \times 25 \mathrm{ft}$ & Mass flow surge bin. \\
\hline 2 & Switchover Bin Reclaim Belt Feeder & 50 & $\begin{array}{l}\text { Design Capacity: } \\
\text { Belt Width: }\end{array}$ & See General Belt Feeder Specification. \\
\hline 2 & Power/Steam Plant Feed Conveyor & 75 & $\begin{array}{l}\text { Design Capacity: } \\
\text { Belt Width: }\end{array}$ & See General Conveyor Specification. \\
\hline 2 & Conversion Coal Feed Conveyor & 300 & $\begin{array}{l}\text { Design Capacity: } \\
\text { Belt Width: }\end{array}$ & See General Conveyor Specification. \\
\hline
\end{tabular}


THIS PAGE

\section{WAS INTENTIONALLY \\ LEFT BLANK}


evenly fill each V-bunker. These tripper conveyor systems are located in the center of the bunker enclosing structure in a conveyor gallery. Coal is discharged into a bunker on both sides of the tripper car through chute work and continuous slots in the gallery floor. Continuous seal belts on the floor slots control escape of dust from the actual bunker into the conveyor gaílery.

Coal is reclaimed from a V-bunker by a rotary plow feeder which travels the entire length of the bunker. Reclaimed coal is discharged from this feeder onto a reclaim conveyor located in a tunnel under the bunker. These conveyors, one per bunker, discharge to one of two transfer conveyors. These conveyors can divert coal to either the power/steam plant or to a twoway switchover bin which feeds coal to conversion. As coal discharges from the transfer conveyor, it is sampled by a sampling system identical to that presented in Figure 5-1.

V-bunker facility filling and reclaiming is completely automatic. Highand low-level instrumentation, tripper car, and reclaimer position indicators provide necessary information to the coal storage operations control room for monitoring and scheduling filling and reclaiming activities. Coal temperature is continuously monitored by thermocouples built into the bunker walls. The thermocouples are connected to a microprocessor which can locate the place of any dangerously elevated coal temperature. To remove hot coal, the rotary plow reclaimer is positioned under its location and is used to reclaim coal from the entire section involved.

In order to obtain high availability, good operating flexibility, and rapid surge bin filling, two conveyors, each capable of meeting normal conversion plant feed requirements, are fed from a two-way switchover bin. Bln discharge outlets are stainlcss eteel lined. 
No flow sheets have been developed for dead coal storage. The multiple dead pile arrangement presented in the coal mine-coal conversion plant interface final report is judged to be well suited for coal conversion plants. In the scheme developed in the interface project, unit dead piles are built, maintained, and reclaimed as follows:

- Dead pile construction - Coal placed in a loose pile by a stacker is spread by rubber-tired dozers and then picked up by 40-cubic-yard scrapers. The scrapers are used to build square packed piles containing approximately 250,000 tons of coal. Once built, the pile tops and sides are covered with an airtight seal of asphalt, road tar, or water-soluble acrylic polymer crusting agent.

- Dead pile maintenance - Piles are inspected visually and by an infrared scanner at least nnce a week. Pile seal cracks are repaired as soon as located.

- Dead pile reclaim - For reclaim, dozers are used to cut a ramp in a sealed pile nearest a reclaim slot. A reclaim slot consists of a rotary plow feeder capable of reclaiming coal piled over it and a below-grade conveyor to which the rotary plow discharges. Once a ramp is built, scrapers are used to move coal to the reclaim slot.

\subsection{COAL FINE CRUSHING CONCEPTUAL FLOW SHEETS}

Nine conceptual flow sheets and major equipment lists have been developed for coal crushing and grinding. Reasons for development of this number of fine crushing flow sheets are: eight of the nine coal conversion processes considered require fine coal feed; the range of different required coal feed size consists within the fine coal classification; possible alternative fine coal crushing approaches; and, a possible need to minimize ultrafines formation during coal fine crushing. Coal fine crushing equipment is also required to prepare coal for the power/steam plant atmospheric pressure fluidized bed (AFB) steam generators. The feed coal top size desirable for AFB steam generators, however, could be as high as $1 / 2$ inch. Though this is a slightly coarser top size than that defined for fine coal flow sheets development, it is well within the capabilities of the type of flow sheets developed to provide $1 / 4$ inch $\times 0$ and $1 / 8$ inch $\times 0$ coal 
for the U-Gas and COGAS processes, respectively. (Fine coal, previously, defined in Subsection 4.3 , is coal which contains particles not greater than $1 / 4$ inch, but not all smaller than 20 mesh in size. Note: a less specific definition of fine coal is used in Subsection 5.2, Coal Cleaning Conceptual Flow Sheets, to be consistent with coal cleaning industry terminology.)

Table 5-2.summarizes most of the different approaches - different fine crushing circuits - for which flow sheets and major equipment lists are presented. These circuits are arranged according to the coal conversion processes for which they were developed. The table also.identifies crusher 'designs specified for each circuit.

In Table 5-2, the proposed fine crushing circuit for each conversion process is that judged, on current technical information, to provide the best combination of reliability and operating flexibility. For most processes this judgement is subjective, could change if ultrafines minimization is important, and is not based on direct comparison of actual costs for competing crushing circuits. Many factors could result in replacement of a proposed circuit by an alternative or completely new circuit. These factors include more definitive conversion reactor.coal feed requirements (particularly for the SRC-I and SRC-II processes), detailed circuit cost estimates, conversion process demonstration plant results, and possible advances in fine crushing technology.

A further principal factor that would determine fine crushing circuit design and equipment specification for an actual commercial coal conversion plant is results of a fine crushing test program. Such a test program would be completely justifiable for crushing facilities of the capacities required for coal conversion. A possible exception would be when the commercial plant feed coal is used in a demonstration plant. In this case a fine crushing assessment program would be part of the demonstration plant test 
Table 5-2

COAL FINE CRUSHING ALTERNATIVES SUMMARY

\begin{tabular}{|c|c|c|c|c|c|c|c|}
\hline Coal & Conversion Process & v-Cas & COGAS & HYCAS & $\begin{array}{c}\text { Texaco Partial } \\
\text { Oxidat fon }\end{array}$ & $\begin{array}{l}\text { Exxon Donor Solvent } \\
\text { And Catalytic } \\
\text { Casification } \\
\end{array}$ & SRC-I And SRC-II \\
\hline 1.0 & $\begin{array}{l}\text { CONVERSION REACTOP } \\
\text { COAL FEED } \\
\text { REQUIREMENTS }\end{array}$ & & & & & & - \\
\hline 1.1 & Size Consist & $\begin{array}{l}100 \text { Percent Minus } \\
1 / 4 \text { Inch. }\end{array}$ & $\begin{array}{l}100 \text { Percent Minus } \\
1 / 8 \text { Inch }\end{array}$ & $\begin{array}{l}100 \text { Percent Minus } \\
14 \text { Mesh }\end{array}$ & $\begin{array}{l}100 \text { Percent Minus } \\
20 \text { Hesh }\end{array}$ & $\begin{array}{l}100 \text { Percent Minus } \\
8 \text { Mesh }\end{array}$ & $\begin{array}{l}100 \text { Percent Minus } \\
12 \operatorname{Mesh}(1)\end{array}$ \\
\hline 1.2 & Fines Lioltations & $\begin{array}{l}\text { Up to } 10 \text { Percent } \\
\text { Minus } 200 \text { Mesh }\end{array}$ & None Reported & $\begin{array}{l}\text { Minimum Minus } \\
100 \text { Mesh }\end{array}$ & Minimum Ultrafines & None Reported & None Reported \\
\hline 1.3 & Total Molsture & $\begin{array}{l}\text { As Recelved (Pitts- } \\
\text { burgh Seam Coal Msy } \\
\text { Requ1,y Yrot, teatment } \\
\text { to Control } \\
\text { Agflomeration? }\end{array}$ & $\begin{array}{l}\text { Drying is Part of } \\
\text { Converston Process }\end{array}$ & $\begin{array}{l}\text { Cóal is Dried During } \\
\text { Prẹtreatment }\end{array}$ & As Recelved & $\begin{array}{l}\text { Drying 1s Part of } \\
\text { Both Sonveroton } \\
\text { Processes }\end{array}$ & $\begin{array}{l}\text { Drying is Part of } \\
\text { nutl Ouriveis luil } \\
\text { Processes }\end{array}$ \\
\hline 2.0 & $\begin{array}{l}\text { FINE CRUSHING } \\
\text { CIRCUITS }\end{array}$ & & . & & & . & \\
\hline 2.1 & $\begin{array}{l}\text { Plupused Pluw } \\
\text { Sheet ard Circult }\end{array}$ & 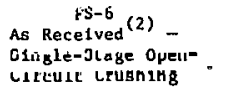 & $\begin{array}{l}\text { FS-6 (2) } \\
\text { As Recelved } \\
\text { SIngle-scage Upén- } \\
\text { Circult truoh1ng }\end{array}$ & $\begin{array}{l}\text { FS-4 (2) } \\
\text { As Recefved } \\
\text { Two-Sțase Qpen- } \\
\text { Citcuit CiusliLitg }\end{array}$ & $\begin{array}{l}\text { FS-4 } \\
\text { As Recelved } \\
\text { Thn-Srape Onen= } \\
\text { Citcult Crushling }\end{array}$ & $\begin{array}{l}-\quad \text { FS-3 } \\
\text { As Recelved }{ }^{(2)}- \\
\text { Singla-srnon mas. } \\
\text { Circult Crushing }\end{array}$ & 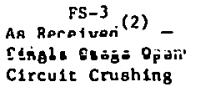 \\
\hline 2.2 & $\begin{array}{l}\text { Alternotive Flow } \\
\text { Sheet and Circult }\end{array}$ & \begin{tabular}{l}
\multicolumn{1}{c}{ FS-8 } \\
Dry to 3 Percent \\
Total Molsture, (3) \\
Screen, and Crush \\
Oversize Coal in \\
Slnigle-Stage, Open- \\
Circuit to Minimize \\
Fines .
\end{tabular} & - & $\begin{array}{l}\quad \text { FS-4-1 (2) } \\
\text { As Recelved } \\
\text { Two-8tage Opcn- } \\
\text { Clrcult Crushing, } \\
\text { Scacked Milis }\end{array}$ & $\begin{array}{l}\text { FS-4-1 }^{(2)} \\
\text { As Received } \\
\text { Two-3tage OptII- } \\
\text { C1rcult Crushing, } \\
\text { Stacked Mills }\end{array}$ & $\begin{array}{l}\quad \text { FS-S }(2)- \\
\text { As Received } \\
\text { S1ngle-Stege llosed- } \\
\text { C1rcuit Crushing }\end{array}$ & $\begin{array}{l}\text { FS-5 } \\
\text { As Recelved (2) - } \\
\text { Single-Stage Closed- } \\
\text { Circult Crushing }\end{array}$ \\
\hline 2.3 & $\begin{array}{l}\text { Alternative Flow } \\
\text { Sheet and Ċircult }\end{array}$ & - & - & $\begin{array}{l}\text { TE-5 }(2)- \\
\text { As Recefved } \\
\text { Singlo-Stage Closed- } \\
\text { Circult Crushing }\end{array}$ & $\begin{array}{l}\quad \text { TOS (í) } \\
\text { As Recelved } \\
\text { S1ngle-Stage Clused- } \\
\text { Circuit Crushing }\end{array}$ & - & - \\
\hline 2.4 & $\begin{array}{l}\text { Altemative flow } \\
\text { Sheet and C1rcult }\end{array}$ & - & - & - & $\begin{array}{l}\text { Fs-10 } \\
\text { As Recelved (2) - } \\
\text { S1ngle-Stage Open- } \\
\text { Circult Grinding }\end{array}$ & . & -. \\
\hline 3.0 & $\begin{array}{l}\text { TYPE OF FINE } \\
\text { CRISSHJNG ERUTPMENT }\end{array}$ & & & & & & \\
\hline 3.1 & Proposed Circult & $\begin{array}{l}\text { Four } 72-\text { Inch, 2-Row } \\
\text { Cage M111s, 600 tph } \\
\text { Each M111 } \\
\text {. }\end{array}$ & $\begin{array}{l}\text { Four } 72-\text { Inch, 2-Row } \\
\text { Cage Mills, } 600 \text { tph } \\
\text { Each M111 }\end{array}$ & 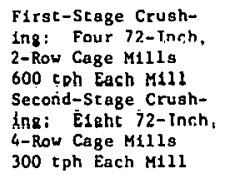 & $\begin{array}{l}\text { First-Stage Crush- } \\
\text { 1ng: Four 72-Inch, } \\
\text { 2-Row Cage M111s } \\
\text { 600 rph Rarh M111 } \\
\text { Second-Stage Crush- } \\
\text { ing: E1ght 12-Tnrh, } \\
\text { 4-Row Cage Mills } \\
\text { 300 tph Each M111 }\end{array}$ & $\begin{array}{l}\text { Six 72-Inch, 4-Row } \\
\text { Cagc M11s, } 400 \mathrm{tph} \\
\text { Each M111 }\end{array}$ & $\begin{array}{l}\text { S1x } 72-\text { Inch, 4-Row } \\
\text { Cage ML118, } 400 \text { tph } \\
\text { Each MIll }\end{array}$ \\
\hline 3.2 & $\begin{array}{l}\text { Alternative } \\
\text { Clrcuit }\end{array}$ & $\begin{array}{l}\text { Four } 60-\text { Inch } x \\
\text { l10-Inch-W1de } \\
\text { Center Feed, } \\
\text { Reversible Harmer- } \\
\text { mills, } 600 \text { tph Each } \\
\text { M111(4) }\end{array}$ & - & 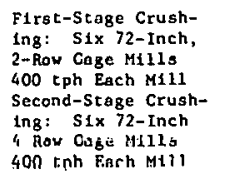 & 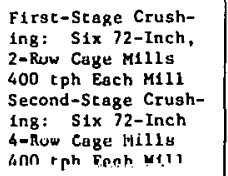 & $\begin{array}{l}\text { Six 72-Inch, 2-Row } \\
\text { Cage Mi11s, } 400 \mathrm{cph} \\
\text { Each M111 }\end{array}$ & $\begin{array}{l}\text { Six 72-Inch, 2-Row } \\
\text { Cage Mil1s, } 400 \mathrm{tph} \\
\text { Each MI11 }\end{array}$ \\
\hline 3.3 & $\begin{array}{l}\text { Alternative } \\
\text { Cipelito }\end{array}$ & $\begin{array}{l}\text { Four } 12-\text { Inch, 2-Row } \\
\text { Cage N111a, 600 eph } \\
\text { Each M111 }(5)\end{array}$ & $\dot{-}$ & $\begin{array}{l}\text { Six } 72 \text {-Inch, 2-Rns } \\
\text { Cage mi11s, 40ü cpn } \\
\text { Eacl M111 }\end{array}$ & 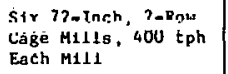 & - & .' \\
\hline 3.4 & $\begin{array}{l}\text { Altemative } \\
\text { idteult }\end{array}$ & - & - & - & $\begin{array}{l}\text { Thirtaan lat-fre } \\
\text { Diametce } x \text { io-ft- } \\
\text { Long Rod Mills } \\
180 \mathrm{tph} \text { Esch M111 }\end{array}$ & - & . \\
\hline
\end{tabular}

Notes:

(1) Gulf Mineral Resources co. Is currently evaluating a range of conversfon reactor coal feed size consists for SRC-I and SRC-II demonstration plants. These range from 100 percent minus 6 mesh (approximately $1 / 8$ inch) to 100 percent minus so mesh.

(2) As Received coal has a noninal size consist of 2 inch $x 0$ and can have up to 10 wt percent total moisture.

(3) Flow Sheet FS-7 1s for soa:se coa! thermal drying.

(4) This alternative crushing equipment is for Flow Sheet FS-6.

(5) This alternative crushing equipment is for Flow Sheet FS-8. 
program. A typical fine crushing test program would be performed using a large representative conversion coal sample and involve testing of several crusher designs, a wide range of crusher operating conditions, and probably different crushing circuits. Its results would quantify for a specific coal the effect of crusher designs and operating conditions on crushed coal size consist. From this information and cost estimates a best crushing circuit design would be achieved.

Unfortunately, as far a's could be determined, results of any comprehensive fine crushing test program on either Pittsburgh or Kentucky No. 9 Seam coals has not been published or otherwise made available in the public domain. As a result; the flow sheets and crusher selections presented in this report are based on general coal fine crushing experience and crusher manufacturer performance estimates.

With, one exception (Flow Sheet FS-10 in Table 5-2), all fine crushing flow sheets use multi-row cage mills. These mills are well suited to conversion coal fine crushing because:

- They have high capacities - on the order of 50,000 tons per day of coal can be crushed with a reasonable number of mills (eight is the maximum number of mills specified for any of the fine crushing flow sheets)

- Compared with other types of fine crushers, ultrafines production is usually lower

- They are of relatively simple design

- Reliability is high

- Maintenance is comparatively easy (cage mills can be designed for rapid cage and lining replacements)

- They are compact in size

- They accept coal with as-received total moisture (crushed coal quality and mill capacity, however, deteriorate as coal moisture concentration increases) 
- They readily accept 2 inch $x 0$ and coarser coal

- Within limits, mill operating conditions, particularly cage speeds and configuration, can be easily changed, if necessary, to accommodate changes in coal comminution characteristics

- Coal conveying-drying gas is not required

- They have comparatively low capital cost

Cage mills crush material primarily by impaction: A typical, high-capacity, multi-row cage mill consists of two or more concentric cages with adjacent cages rotating in opposite directions. Each cage consists of rows of round bars supported at both ends by rings. Alternate rings are connected through shafts to separate drives for counter-rotation of adjacent cages. Coal is gravity fed into the center of the revolving inner cage. Centrifugal force impacts it against the inner cage bars and successive cages until it finally impacts against breaker plates lining the mill housing. After some rebounding back into the cages, crushed coal exits at the mill base.

Major cage mill variables which affect final product size consist are:

- Cage sperds

- Cage bar spacing

- Number of cages (rows)

- Whether or not the mill is in an open or closed crushing circuit. (In closed-clrcult crushing, mill product is classified and oversize material is returned to the mill for further crushing.)

- Number of crushing stages

With exception of FS-10, in which wet rod mills are used to produce 100 percent minus 20 mesh coal slurry, all fine crushing flow sheets use belt conveyors for coarse and fine coal transport; bins for coal surge storage; gravimetric 
belt feeders for cage mill feeding; and, cage mills: Design capacities established for these components are based on reliability considerations and the need to provide coal to a postulated five-train coal conversion plant. With exception of FS-4, two cage mill capacities were judged to meet these general requirements: 600 and 400 tons per hour. Use of these two design capacities results in:

- A reasonable number of cage mili trains

- No extrapolation of current cage mill designs

- Sufficient excess mill capacity when required

- Specification of fine coal conveyors well within existing conveyor capacities

Flow sheets that are consistent with the level of current cage mill coal crushing performance data

Major equipment list specified cage mill power requirements are based on use of the largest drives (multi-row cage mills require two drivers, one for each cage, set) recommended by manufacturers for a given mill size. Actual mill power consumption would normally not reach the specified rates. However, the cost savings associated with specifying lower power drives, such as 1,000 instead of $1,200 \mathrm{hp}$, is insignificant compared with fine crushing facilịty capital cost and sacrifices operating flexibility. Specification of maximum design power for crushers is normal practice in the minerals beneficiation industry.

The number of cage mills required for a flow sheet establishes the number of mill feeders and surge bins required. Each mill is supplied by a single graviimetric belt feeder and a single surge bin. Belt feeders capable of feeding up to 600 tons per hour of coal appear to be technically feasible. However, if necessary multiple feeders could be used for a single cage mill. 
Fine crushing surge bin design capacities are based on providing an approximate coal residence time of one hour. This is sufficient for the surge storage filling tripper conveyor systems to maintain bins sufficiently full at all times. Design of multiple surge bin systems of the types presented in the flow sheets is very involved. In addition to the bin design considerations mentioned in the beginning of this section, it requires design of the complete system used to sequentially fill all bins. The bin design capacities presented in the major equipment lists are only estimates. Detailed engineering and cost trade-offs could result in somewhat different bin capacities.

Coal is conveyed to and from all fine crushing operations by belt conveyors. For both applications two full-capacity conveyor systems are provided. Each coal conveyor system has a 1.33 equipment design capacity to plant design capacity ratio. The equipment design capacity is that specified for equipment procurement. (Equipment design capacities are the capacities presented in major equipment lists.) Plant design capacity for all fine crushing flow sheets is 1,771 tons per hour ( $t p h)$ of coal having a total moisture concentration of 8.0 wt percent. This is equivalent to 42,500 tons per day of conversion reactor feed coal or 85 percent of the entire conversion plant design daily coal culsumiption of 50,000 tone per day. I'the other 15 percent of daily coal consumption is consumed in the power/steam plant. Plant design capacities at various points in the fine crushing flow sheets are presented in the material balances associated with each tlow shèer.

The conveyor system equipment design/plant design capacities ratio of 1.33 was established because it provides:

- Extra conveyor capacity to avoid spillage due to inadvertent overloading

- Faster fine crushing surge storage filling when required 
- A safety margin for off-specification crusher performance

- For near plant design surge storage bin filling with a single conveyor system, i.e., when the other bin filling conveyor system is out of service

In all coal fine crushing flow sheets, surge storage bins were postulated as being located in a single row. This configuration is well suited for providing coal to a conversion plant consisting of five, parallel coal conversion trains. Efficient transfer of coal to the conversion reactor feed systems could be achieved by location of the fine crushing facility at the coal feed ends of the conversion trains with the surge bin row perpendicular to the train centerlines. Obviously, many layouts for matching of coal fine crushing and conversion reactor feed systems are possible. However, evaluation of such layout alternatives is beyond the scope of this report.

Use of an in-line bin layout results in an uncomplicated filling tripper conveyor system and bin discharging operation. It also would be easy to expand in stages; new bins being added at one end. Feed to the entire row of surge bins was postulated as being at one end of the row. A center feed point could, however, have advantages for a large number of in-row bins.

The coal fine crushing flow sheets provide both high operating reliability and operating flexibility. However, it should be recognized that different design approaches could result in flow sheets with comparable operating reliability and flexibility. Actual commercial fine crushing plant designs are always a compromise between achievement of high reliability, operating flexibility considerations, capital costs, and operating costs.

\subsubsection{Coal Fine Crushing Without U1trafines Removal}

Flow Sheet FS-3 is the proposed fine crushing circuit for preparing 8 mesh $x$ ? coal (coal feed for the Exxon Donor Solvent and Exxon Catalytic Gasification Processes) and 12 mesh $x 0$ coal (coal feed for the 
SRC-I and SRC-II Processes). These two different crushed coal size distributions could be obtained by use of different cage mill speeds and possibly slightly different cage bar spacings. Cage mill design capacities and installed powers would, however, be identical or very similar for both size distributions.

Coarse coal ( 2 inch $\times 0$ ) is conveyed from live storage by a parallel conveyor system consisting of two, 2,400 tons per hour, 60-inch-wide conveyors. Length of these conveyors is dependent on live storage facility type and layout, coal conversion plant layout, and fine crushing surge storage height. Since plant layouts are not part of conceptual flow sheets development, no lengths, and as a result no installed power, have been estimated for these conversion coal fine crushing feed conveyors. Suitable conveyors for this service are commerically available.

Fine crushing feed conveyors are provided with tramp iron magnets, and for non-magnetics removal, electronic type metal dectectors. The tramp iron magnets are self-cleaning. Removed metal is collected in a bin and periodically removed. When a metal detector senses a. sufficiently large piece of metal it marks its location with a paint spray and sounds an alarm. Frequently such metal detectors are interlocked with their conveyor to stop it when metal is detected. Metal is then removed manually. Removal of tramp metal is important for protection of the cage mills and other coal handling equipment.

Each fine crushing feed conveyor discharges onto a surge storage tripper conveyor syștem. Two independent tripper conveyor systems are provided for filling of fine crushing surge bins. Each system is similar to those described in subsection 5.3 for V-bunker live coal ecorage. Each conslsts of a level belt conveyor running over the tops of in-line surge bins and a self-propelled tripper car. The tripper car can discharge coal from the conveyor into any bin. When one bin is full the car is moved to another bin where coal is required. Tripper cars of the capacities required for 


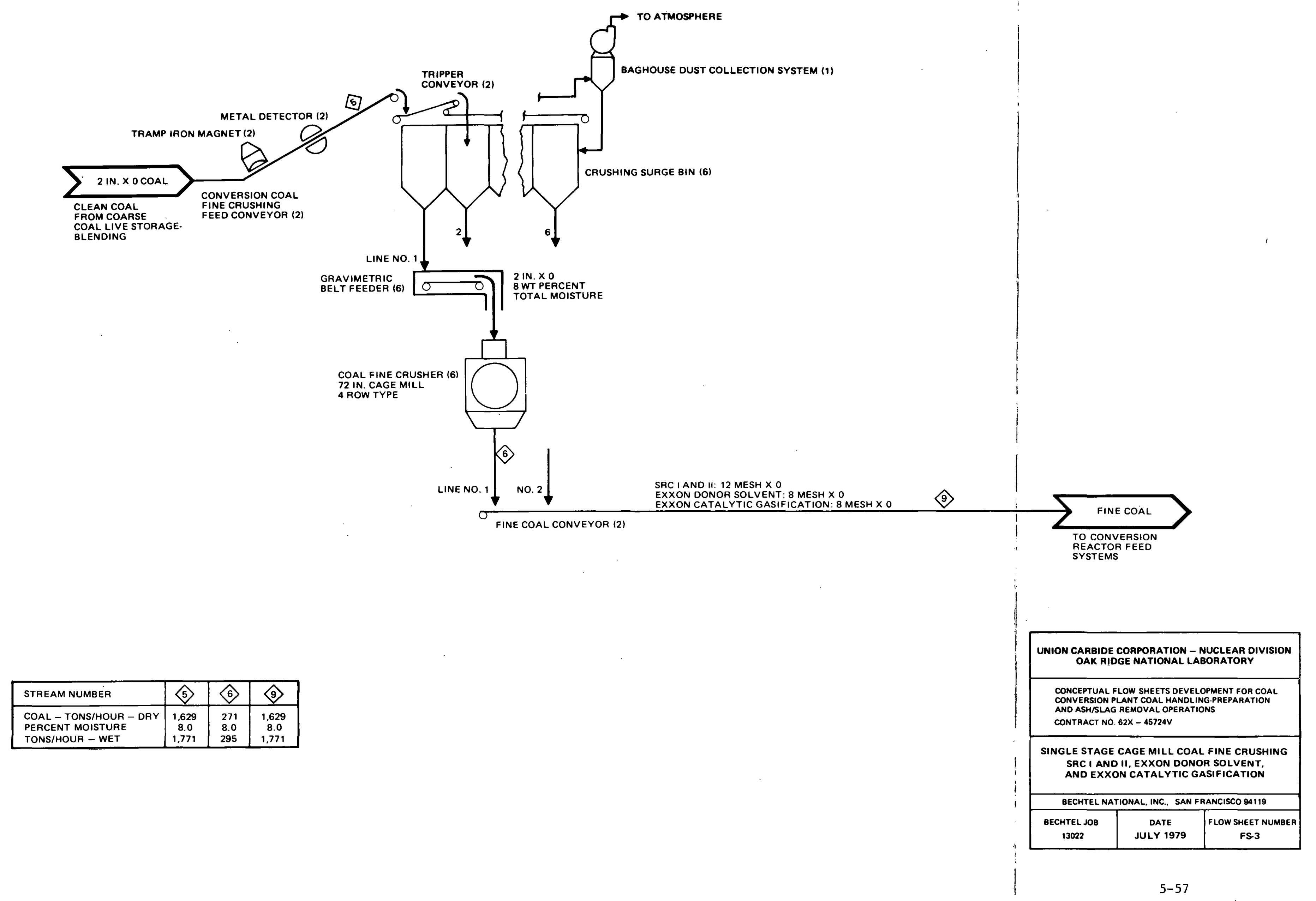


THIS PAGE

\section{WAS INTENTIONALLY \\ LEFT BLANK}


MAJOR EQUIPMENT LIST

SINGLE-STAGE CAGE MILL COAL FINE CRUSHING FLOW SHEET FS-3

\begin{tabular}{|c|c|c|c|c|}
\hline $\begin{array}{l}\text { Number } \\
\text { Required }\end{array}$ & Equipment Title & $\begin{array}{c}\mathrm{HP} \\
\text { Each }\end{array}$ & Design Rating and Description & Specification Requirements and Comments \\
\hline 2 & $\begin{array}{l}\text { Fine Crushing Surge Storage } \\
\text { Tripper Conveyor System }\end{array}$ & 150 & $\begin{array}{l}\text { Design Capacity: } \\
\text { Belt Width: }\end{array}$ & See General Conveyor Specification. \\
\hline 6 & Fine Crushing Surge Bin & - & $\begin{array}{cc}\text { Design Capacity: } & 300 \text { tons } \\
(1,800 \text { tons, total combined capacity })\end{array}$ & $\begin{array}{l}\text { Mass flow bin with lined bottom for even flow } \\
\text { promotion. }\end{array}$ \\
\hline 1 & $\begin{array}{l}\text { Fine Crushing Surge Bins Baghouse } \\
\text { Dust Collection System }\end{array}$ & 60 & Design Capacity: & Standard Baghouse System. \\
\hline 6 & $\begin{array}{l}\text { Fine Crushing Gravimetric Belt } \\
\text { Feeder }\end{array}$ & 25 & $\begin{array}{lr}\text { Design Capacity: } & 400 \mathrm{tph} \\
\text { Belt Width: } & 72 \mathrm{in.}\end{array}$ & See General Gravimetric Belt Feeder Specification. \\
\hline 6 & Coal Fine Crusher & 1,400 & $\begin{array}{l}\text { Design Capacity: } \quad 400 \text { tph } \\
\text { Type: Four Row Cage Mill } \\
\text { Size: }\end{array}$ & See General Cage Mill Specification. \\
\hline 2 & Fine Coal Conveyor & 300 & $\begin{array}{l}\text { Design Capacity: } \\
\text { Belt Width: }\end{array}$ & See General Conveyor Specification. \\
\hline
\end{tabular}


THIS PAGE

\section{WAS INTENTIONALLY \\ LEFT BLANK}


surge storage filling would be specially designed. Their design would provide for such features as minimization of dust generation during conveyor discharge, rapid movement, and highly automated, and possible computer controlled, bin filling. Tripper car operation could be monitored by a closed-circuit television system.

Coal is discharged from the mass flow surge bins by sealed gravimetric belt feeders. Height of the downspout connecting feeders and bins is designed to provide a head seal against feeder operating pressure. Each feeder discharges directly into a cage mill feed chute. Spinning of mill cages produces a certain amount of air flow which must be controlled. This is accomplished by the pressurized, sealed feeders.

Actual coal crushing is accomplished in six, 72-inch, four-row cage mills ( 72 inch is the diameter of the outer mill cage). Each mill is driven by two motors: an 800-hp motor for the large cage and a 600-hp motor for the small cage. Crushed coal is discharged from each mill by means of flow switching chutes onto one of two fine coal conveyors. For the EDS Process, SRC-I, and SRC-II these conveyors convey coal to a series of coal-solvent slurrying vessels.

Flow sheet FS-4 is the proposed fine crushing circuit for preparing 14 mesh $x 0$ coal (HYGAS coal feed) and 20 mesh $x 0$ coal (Texaco Partial Oxidation Gasification coal feed). : First-stage crushing is very similar to FS-3; the main difference being use of larger capacity, 2-row-type cage mills.

Coal from first-stage crushing is conveyed by a scissor conveyor system to a second tripper conveyor system which fills eight, in-line second stage crushing surge bins. Feed of coal from these bins is identical to that for first-stage crushing. Second-stage crushing is accomplished in 
eight, 72-inch, four-row cage mills. These mills discharged to one of two fine coal conveyors.

Flow sheet FS-4-1 presents an alternative two-stage open-circuit fine crushing arrangement. It makes use of stacked mills which avoids use of conveyors and surge bins between first and second stage crushings. Capital cost of this arrangement is usually less than for that presented in FS-4. However, it has less operating flexibility and is less efficient than the FS-4 arrangeiment.

Flow sheet FS-5 is an alternative flow sheet for both FS-3 and FS 4 . Instead of open circuit crushing, it uses closed-circuit fine crushing. The main advantages of this flow scheme are reduced ultrafines production and higher crushing efficiency, i.e., the power consumption required for closed-circuit crushing is less than for comparable open-circuit crushing. A disadvantage is its greater complexity compared with open-circuit crushing and, as a result, higher cost.

In FS-5 coal classification is achieved in air classifiers. Classification oversize is conveyed by a scissor conveyor system to surge storage befure additional size reduction. Coarse coal feed from live storage is also conveyed by this same scissor conveyor system to surge storage. Coal is fed from surge storage to cage mills in a manner analogous to that described for FS-3 and $\mathrm{F}^{\mathrm{S}} \mathrm{-}-4$.

Crushed coal gravity flows from each cage mill into the feed spout of an air classifier. Here $1 \mathrm{t}$ is pluked up by a iulating distributing plate hub. Centrifugal force, imparted to the coal particles by the hub, Lhruws Lliem through a series of openings onto a distributing plate. The coarsest (heaviest) particles after leaving this plate settle into a tailings cone. Finer particles are entrained in ascending air currents created by an internal classifier fan. These particles are swept through radial selector blades which impart additional centrifugal force. In this secondary classification, the finest particles are retained in the classifier circulating air. 


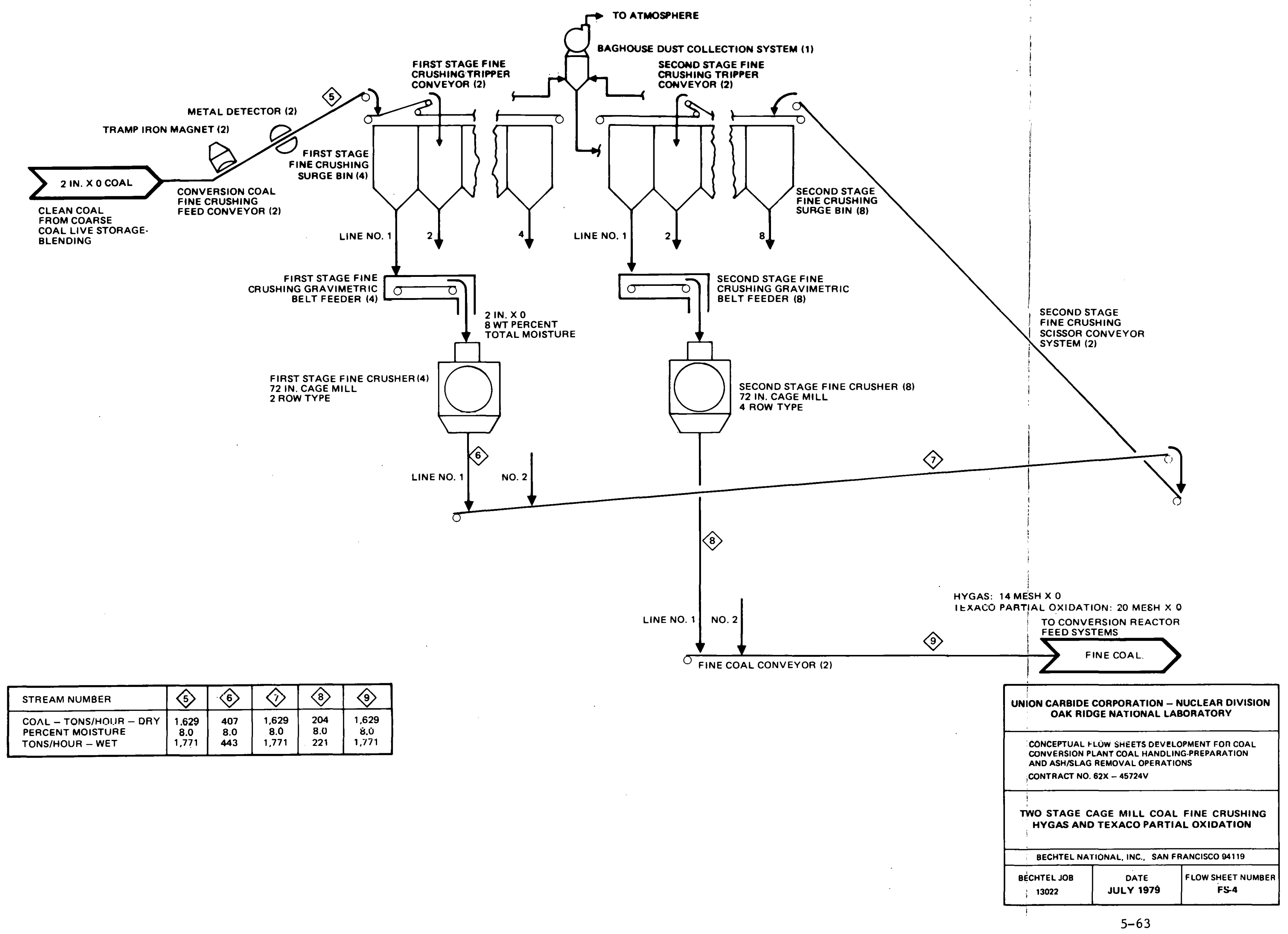


THIS PAGE

WAS INTENTIONALLY

LEFT BLANK 
MAJOR EQUIPMENT LIST

TWO-STAGE CAGE MILL COAL FINE CRUSHING FLOW SHEET FS-

\begin{tabular}{|c|c|c|c|c|}
\hline $\begin{array}{l}\text { Number } \\
\text { Required }\end{array}$ & Equipment Title & $\begin{array}{l}\mathrm{HP} \\
\text { Each }\end{array}$ & Design Rating and Description & Specification Requirements and Comments \\
\hline 2 & $\begin{array}{l}\text { First-Stage Fine Crushing Surge } \\
\text { Storage Tripper Conveyor System }\end{array}$ & 150 & $\begin{array}{l}\text { Design Capacity: } \\
\text { Be1t Width: }\end{array}$ & See General Conveyor Specification. \\
\hline 4 & $\begin{array}{l}\text { First-Stage Fine Crushing Surge } \\
\text { Bin }\end{array}$ & - & $\begin{array}{l}\text { Design Capacity: } 225 \text { tons } \\
\text { ( } 900 \text { tons, total combined capacity) }\end{array}$ & $\begin{array}{l}\text { Mass flow bin with lined bottom for even flow } \\
\text { promotion. }\end{array}$ \\
\hline 4 & $\begin{array}{l}\text { First-Stage Fine Crushing Gravi- } \\
\text { metric Belt Feeder }\end{array}$ & 30 & $\begin{array}{l}\text { Design Capacity: } \\
\text { Belt Width: }\end{array}$ & $\begin{array}{l}\text { See General Gravimetric Belt Feeder } \\
\text { Specification. }\end{array}$ \\
\hline 4 & First-Stage Coal Fine Crusher & 1,200 & $\begin{array}{lr}\text { Design Capacity: } & 600 \mathrm{tph} \\
\text { Type: } & \text { Two Row Cage Mill } \\
\text { Size: } & 72 \text { in. diameter }\end{array}$ & See General Cage Mill Specification. \\
\hline 2 & $\begin{array}{l}\text { Second-Stage Fine Crushing } \\
\text { Scissor Conveyor System }\end{array}$ & 500 & $\begin{array}{l}\text { Design Capacity: } \\
\text { Belt Width: }\end{array}$ & See General Conveyor Specification. \\
\hline 2 & $\begin{array}{l}\text { Second Stage Fine Crushing Surge } \\
\text { Storage Tripper Conveyor System }\end{array}$ & 200 & $\begin{array}{l}\text { Design Capacity: } \\
\text { Belt Width: }\end{array}$ & See General Conveyor Specification. \\
\hline 8 & $\begin{array}{l}\text { Second-Stage Fine Crushing Surge } \\
\text { Bin }\end{array}$ & - & $\begin{array}{lc}\text { Design Capacity: } & 225 \text { tons } \\
(1,800 \text { tons, } \text { total combined capacity })\end{array}$ & $\begin{array}{l}\text { Mass flow bin with lined bottom for even flow } \\
\text { promotion. }\end{array}$ \\
\hline 8 & $\begin{array}{l}\text { Second-Stage Fine Crushing Gravi- } \\
\text { metric Belt Feeder }\end{array}$ & 20 & $\begin{array}{l}\text { Design Capacity: } \\
\text { Belt Width: }\end{array}$ & $\begin{array}{l}\text { See General Gravimetric Belt Feeder } \\
\text { Specification. }\end{array}$ \\
\hline 8 & Second-Stage Coal Fine Crusher & 1,400 & $\begin{array}{ll}\text { Design Capacity: } & 300 \mathrm{tph} \\
\text { Type: } & 4 \text { Row Cage Mill } \\
\text { Size: } & 72 \text { in. diameter }\end{array}$ & See General Cage Mill Specification. \\
\hline 2 & Fine Coal Conveyor & 300 & $\begin{array}{lr}\text { Design Capacity: } & 2,400 \mathrm{tph} \\
\text { Belt Width: } & 60 \mathrm{in} .\end{array}$ & See General Conveyor Specification. \\
\hline 1 & $\begin{array}{l}\text { Fine Crushing Surge Bins Baghouse } \\
\text { Dust Collection System }\end{array}$ & 150 & Design Capacity: & Standard Baghouse System. \\
\hline
\end{tabular}


THIS PAGE

WAS INTENTIONALLY

LEFT BLANK 


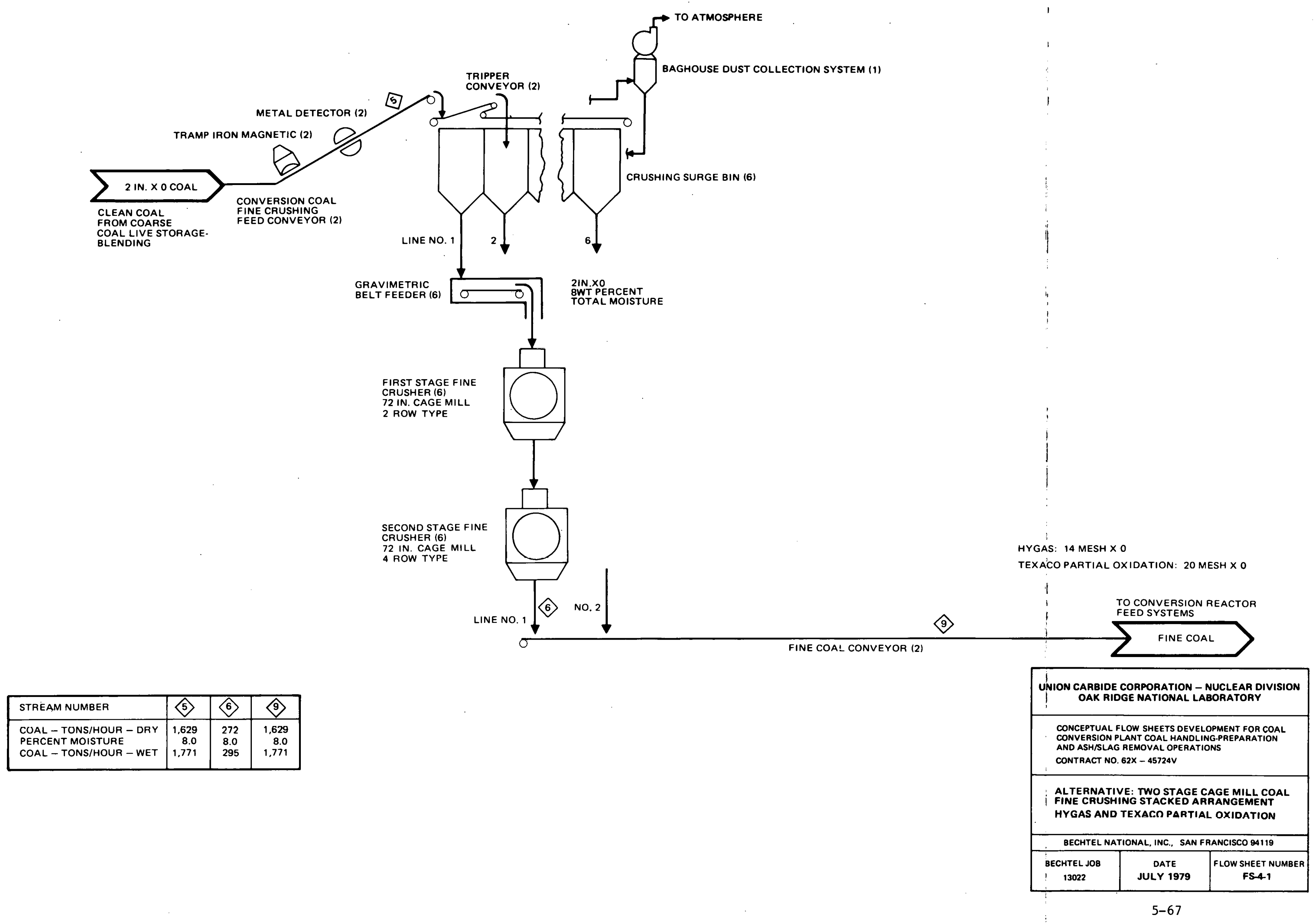


THIS PAGE

\section{WAS INTENTIONALLY LEFT BLANK}


MAJOR EQUIPMENT LIST

TWO-STAGE CA'GE MILL COAL FINE CRUSHINC STACKED CRUSHER ARRANGEMENT ALTERNATIVE FLOW SHEET FS-4-

\begin{tabular}{|c|c|c|c|c|}
\hline $\begin{array}{l}\text { Number } \\
\text { Required }\end{array}$ & Equipment Title & $\begin{array}{c}\mathrm{HP} \\
\text { Each }\end{array}$ & Design Rating and Description & Specification Requirements and Comments \\
\hline 2 & $\begin{array}{l}\text { Fine Crushing Surge Storage Tripper } \\
\text { Conveyor System }\end{array}$ & 150 & $\begin{array}{l}\text { Design Capacity: } \\
\text { Belt Width: }\end{array}$ & See General Conveyor Specification. \\
\hline 6 & Fine Crushing Surge Bin & - & $\begin{array}{lc}\text { Design Capacity: } & 300 \text { tons } \\
(1,800 \text { tons, total combined capacity })\end{array}$ & $\begin{array}{l}\text { Mass flow bin with lined bottom for even flow } \\
\text { promotion. }\end{array}$ \\
\hline 6 & Fine Crushing Gravimetric Belt Feeder & 30 & $\begin{array}{l}\text { Design Capacity: } \\
\text { Belt Width: }\end{array}$ & $\begin{array}{l}\text { See General Gravimetric Belt Feeder } \\
\text { Specification. }\end{array}$ \\
\hline 6 & First-Stage Coal Fine Crusher & 1,200 & $\begin{array}{ll}\text { Design Capacity: } & 400 \mathrm{tph} \\
\text { Type: } & \text { Two Row Cage Mill } \\
\text { Size: } & 72 \text { in. diameter }\end{array}$ & See General Cage Mill Specification, \\
\hline 6 & Second-Stage Coal Fine Crusher & 1,400 & $\begin{array}{ll}\text { Design Capacity: } & 400 \mathrm{tph} \\
\text { Type: } & 4 \text { Row Cage Mill } \\
\text { Size: } & 72 \text { in. diameter }\end{array}$ & See General Cage Mill Specification. \\
\hline 2 & Fine Coal Conveyor & 300 & $\begin{array}{lr}\text { Design Capacity: } & 2,400 \mathrm{tph} \\
\text { Belt Width: } & 60 \mathrm{in} .\end{array}$ & See General Conveyor Specification. \\
\hline 1 & $\begin{array}{l}\text { Fine Crushing Surge Bins Baghouse } \\
\text { Dust Collection System }\end{array}$ & 60 & Design Capacity: & Standard Baghouse System. \\
\hline
\end{tabular}


THIS PAGE

\section{WAS INTENTIONALLY \\ LEFT BLANK}


THIS PAGE

WAS INTENTIONALLY

LEFT BLANK 
MAJOR EQUIPMENT LIST

SINGLE-STAGE CLOSED-CIRCUIT CAGE

MILL COAL FINE CRUSHING

TO MINIMIZE ULTRAFINES

PRODUCTIUIV

ALTERNATIVE FLOW SHEET FS-5

\begin{tabular}{|c|c|c|c|c|}
\hline $\begin{array}{l}\text { Number } \\
\text { Required }\end{array}$ & Equipment Title & $\begin{array}{c}\mathrm{HP} \\
\text { Each }\end{array}$ & Design Rating and Description & Specification Requirements and Comments \\
\hline 2 & $\begin{array}{l}\text { Coal Fine Crushing Recirculation } \\
\text { Scissor Conveyor System }\end{array}$ & 300 & $\begin{array}{l}\text { Design Capacity: } \\
\text { Belt Width: }\end{array}$ & See General Conveyor Specification. \\
\hline 2 & $\begin{array}{l}\text { Fine Crushing Surge Storage Tripper } \\
\text { Conveyor System }\end{array}$ & 200 & $\begin{array}{l}\text { Design Capacity: } \\
\text { Belt Width: }\end{array}$ & See General Conveyor Specification. \\
\hline 6 & Fine Crushing Surge Bin & - & $\begin{array}{l}\text { Design Capacity: } \quad 300 \text { tons } \\
(1,800 \text { tons, total combined capacity })\end{array}$ & $\begin{array}{l}\text { Mass flow bin with lined bottom for even flow } \\
\text { promotion. }\end{array}$ \\
\hline 6 & $\begin{array}{l}\text { Fine Crushing Gravimetric Belt } \\
\text { Feeder }\end{array}$ & 30 & $\begin{array}{lr}\text { Design Capacity: } & 400 \text { tons } \\
\text { Belt Width: } & 72 \text { in. }\end{array}$ & $\begin{array}{l}\text { See General Gravimetric Belt Feeder } \\
\text { Specification. }\end{array}$ \\
\hline 6 & Coal Fine Crusher & 1,000 & $\begin{array}{lr}\text { Design Capacity: } & 400 \mathrm{tph} \\
\text { Type: } & 2 \text { Row Cage Mill }\end{array}$ & See General Cage Mill Specification. \\
\hline 6 & Crushed Coal Air Classifier & 400 & $\begin{array}{l}\text { Design Capacity: } \quad 400 \mathrm{tph} \\
\text { Type: } \quad \text { Mechanical Centrifugal } \\
\text { Size: } \\
\text { Air Separator } \\
\quad 22 \mathrm{ft} \text { diameter }\end{array}$ & $\begin{array}{l}\text { Air separators of up to } 24 \mathrm{ft} \text { in diameter are } \\
\text { currently used for closed-circuit cement } \\
\text { grinding. } \\
\text { Abrasion resistant steel lined. }\end{array}$ \\
\hline 2 & Fine Coal Conveyor & 300 & $\begin{array}{lr}\text { Design Capacity: } & 2,400 . \mathrm{tph} \\
\text { Belt Width: } & 60 \mathrm{in} .\end{array}$ & See General Conveyor Specification. \\
\hline 1 & $\begin{array}{l}\text { Fine Crushing Surge Bins Baghouse } \\
\text { Dust Co11ertion System }\end{array}$ & 60 & Design Capacity: & Standard Baghouse System: \\
\hline
\end{tabular}




\section{THIS PAGE}

WAS INTENTIONALLY

LEFT BLANK 
Oversize particles are thrown out of the accelerated ascending air and settle into the same tailings cone as the coarsest particles. From here they are discharged to a recirculation scissor conveyor system by means of rotary valves and flow switching chute work. Fines swept through secondary classification are cycloned in a fines chamber formed by the conical classifier housing. Removed fines are collected in a fines cone from which they are discharged by rotary valves and flow switching chute work to one of two fine coal conveyors.

Air classifiers of the type specified are widely used in closed-circuit cement grinding. Currently these classifiers are available in diameters up to at least 24 feet. Particle classification size is controlled primarily by changing the number and size of the secondary classification selector blades. During operation classification size is controlled by adjusting air circulation volume. This is accomplished with a series of peripheral vanes which are actuated remotely.

Flow sheet FS-6 is the proposed fine crushing circuit for preparing $1 / 4$ inch $x 0$ coal (U-Gas coal feed) and $1 / 8$ inch $x 0$ coal (COGAS coal feed). Except for the number of parallel trains and fine crusher specification, this flow sheet is similar to FS-3. The FS-3 general coal flow pattern description also applies to this flow sheet.

Two crusher alternatives are specified for production of $1 / 4$ inch $x 0$ coal: two-row-type cage milis and hammermills. Use of hammermills would result in more fines, but save in power comsumption. Hammermills, however, are not recommended to produce minus $1 / 8$ inch $x 0$ coal due to their excessive production of oversize material.

In addition to closed-circuit fine crushing, FS-5, two other flow sheets were developed with ultrafines minimization $1 \mathrm{~m}$.nd. Buth of the re rcquirs relatively dry coal feed. Therefore, a coarse coal drying flow sheet was

\section{Preceding page blank $5-75$}


dcveloped. This flow sheet, FS-7, uses a conventional fluid-bed coal dryer. Drying gas for this dryer is, however, obtained from the power/steam plant. This approach has two main advantages compared with the conventional approach of using dryer product coal as an energy source. It is more energy-efficient. And, second, since the power/steam plant uses fluidized-bed steam generators with limestone injection, the drying flue gas does not require sulfur oxides removal following coal drying.

In FS-7, before drying, coal is handled in equipment very similar to that described for FS-3. Gravimetric bolt feeders are used to fued coal from three in-line surge bins to three identical, parallel fluid-bed coal dryers. Fine coal entrained in dryer flue gas is removed by cyclones and baghouses in series. Fine coal recovered by the dryer cyclones is discharged through rotary valves and flow switching chute work to one of two parallel fine coal conveyors. Here it combines with coarse coal discharged directly from the dryers. Ultrafine coal removed by the dryer baghouse systems could be combined with the coarse coal on the fine coal conveyors without further preparation if ultrafines are acceptable conversion reactor feed. If ultrafines are detrimental to conversion reactor operation they could be conveyed by mass flow conveyors to an ultrafines treatment nperation. Thic second ultrafines alternative is the one shown in FS-7.

FS- 8 is a flow sheet for minimizing ultrafines in $1 / 4$ inch $\times 0$ crushed coal (U-Gas coal feed). Dried coarse cnal, 2 inch $x$, is jerèened in duubledeck, vibrating screens to separate minus $1 / 4$ inch coal. Undcrsize roal. is discharged directly to fine coal conveyors for conveying to the II-fias reactor lock feed system or pretreater. Screen oversize is conveyed by a scissor conveyor system in series with a tripper conveyor system to surge" storage. From here it is crushed to minus $1 / 4$ inch top size in two-row cage mills. These discharge directly to the fine coal conveyors where crushed coal and screening undersize are combined. 
MAJOR EQUIPMENT LIST

SINGLE-STAGE CAGE MILL COAL FINE CRUSHING FLOW SHEET FS-6

\begin{tabular}{|c|c|c|c|c|}
\hline $\begin{array}{l}\text { Number } \\
\text { Required }\end{array}$ & Equipment Title & $\begin{array}{c}\mathrm{HP} \\
\mathrm{Each}\end{array}$ & Design Rating and Description & Specification Requirements and Comments \\
\hline 2 & $\begin{array}{l}\text { Fine Crushing Surge Storage } \\
\text { Tripper Conveyor System }\end{array}$ & 150 & $\begin{array}{lr}\text { Design Capacity: } & 2,400 \mathrm{tph} \\
\text { Belt Width: } & 60 \mathrm{in} .\end{array}$ & See General Conveyor Specification. \\
\hline 4 & Fine Crushing Surge Bin & - & $\begin{array}{l}\text { Design Capacity: } 225 \text { tons } \\
(900 \text { tons, total combined capacity). }\end{array}$ & $\begin{array}{l}\text { Mass flow bin with lined bottom for flow } \\
\text { promotion. }\end{array}$ \\
\hline 1 & $\begin{array}{l}\text { Fine Crushing Surge Bins Baghouse } \\
\text { Dust Collection System }\end{array}$ & 60 & Design Capacity: & Standard Baghouse System. \\
\hline 4 & $\begin{array}{l}\text { Fine Crushing Gravimetric Belt } \\
\text { Feeder }\end{array}$ & 40 & $\begin{array}{l}\text { Design Capacity: } \\
\text { Belt Width: }\end{array}$ & See General Gravimetric Belt Feeder Specification. \\
\hline 4 & Coal Fine Crusher & 1,200 & $\begin{array}{l}\text { Design Capacity: } 600 \text { tph } \\
\text { Type: Two Row Cage Mill } \\
\text { Size: }\end{array}$ & See General Cage Mill Specification. \\
\hline 4 & $\begin{array}{l}\text { Alternative U-Gas Process Coal } \\
\text { Fine Crusher - Hammermill }\end{array}$ & 600 & $\begin{array}{l}\text { Design Capacity: } \quad 600 \mathrm{tph} \\
\text { Type: Center Feed, Reversible } \\
\text { Size: } \\
\begin{array}{c}60 \text { in. diameter } \mathrm{x} \\
\\
\end{array}\end{array}$ & See General Cage Mill Specification. \\
\hline 2 & Fine Coal Conveyor & 300 & $\begin{array}{lr}\text { Design Capacity: } & 2,400 \mathrm{tph} \\
\text { Belt Width: } & 60 \mathrm{in} .\end{array}$ & See General Conveyor Specification. \\
\hline
\end{tabular}


THIS PAGE

WAS INTENTIONALLY

LEFT BLANK 


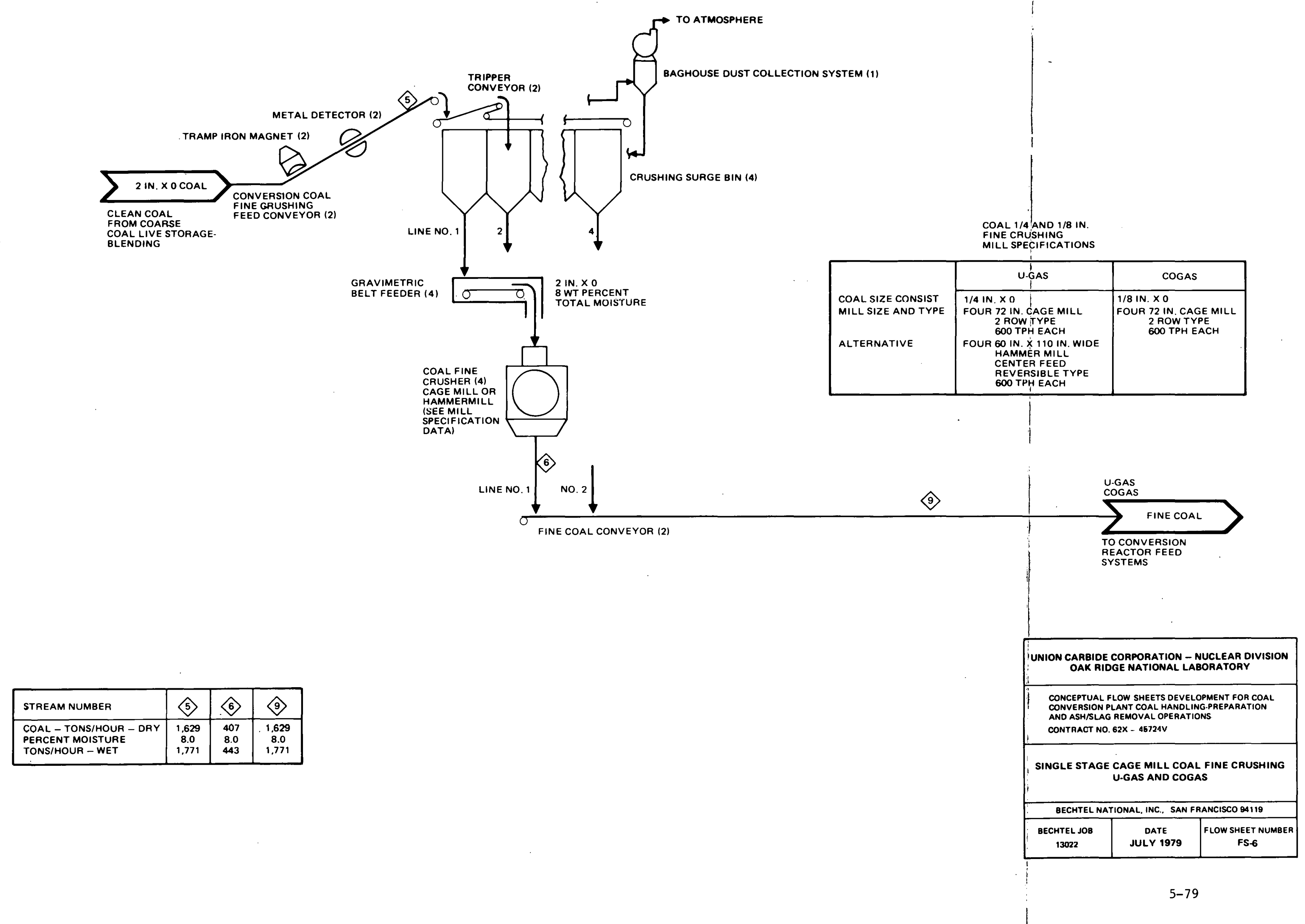




\section{THIS PAGE}

\section{WAS INTENTIONALLY \\ LEFT BLANK}




\begin{tabular}{|c|c|c|c|c|}
\hline $\begin{array}{c}\text { Number } \\
\text { Required }\end{array}$ & Equipment Title & $\begin{array}{c}\mathrm{HP} \\
\text { Each }\end{array}$ & Design Rating and Description & Specification Requirements and Comments \\
\hline 2 & $\begin{array}{l}\text { Coal Dryer Surge Bin } \\
\text { Tripper Conveyor System }\end{array}$ & 100 & $\begin{array}{l}\text { Design Capacity: } \\
\text { Belt Width: }\end{array}$ & See General Conveyor Specification. \\
\hline 3 & Coal Dryer Surge Bin & 3 & $\begin{array}{l}\text { Design Capacity: } 135 \text { tons } \\
(400 \text { tons, total combined capacity) }\end{array}$ & $\begin{array}{l}\text { Mass flow bin with lined bottom for even flow } \\
\text { promotion. }\end{array}$ \\
\hline 3 & $\begin{array}{l}\text { Coal Dryer Gravimetric Belt } \\
\text { Feeder }\end{array}$ & 50 & $\begin{array}{l}\text { Design Capacity: } \\
\text { Belt Width: }\end{array}$ & $\begin{array}{l}\text { See General Gravimetric Belt Feeder } \\
\text { Specification. }\end{array}$ \\
\hline 3 & Fluid Bed Coal Dryer & $\begin{array}{l}2,300 \\
\text { (Total } \\
\text { System) }\end{array}$ & $\begin{array}{l}\text { Design Capacity: } \quad \begin{array}{r}850 \mathrm{tph} \\
\text { Size: }\end{array} \quad 16 \mathrm{ft} \text { diameter }\end{array}$ & $\begin{array}{l}\text { Fluid bed coal dryers of this capacity are currently } \\
\text { available. } \\
\text { Use of flue gas from a power/steam plant instead of } \\
\text { direct firing of coal will require some design } \\
\text { modifications. } \\
\text { Dryers of this capacity are all specially engi- } \\
\text { neered and custom fabricated. }\end{array}$ \\
\hline 18 & Coal Dryer Cyclone & - & $\begin{array}{lr}\text { Design Capacily: } & 62,500 \text { acfm } \\
\text { Size: } & 84 \text { in. diameter }\end{array}$ & $\begin{array}{l}\text { Cyclones of this size are of standard design. } \\
\text { Cyclones are manifolded together in a single } \\
\text { cluster which share a single underflow bin. }\end{array}$ \\
\hline 3 & $\begin{array}{l}\text { Coal Dryer Baghouse } \\
\text { Particulate Coal Collection } \\
\text { System }\end{array}$ & - & $\begin{array}{lr}\text { Design Capacity: } & 500,000 \text { acfm } \\
\text { Area/Baghouse: } & 250,000 \mathrm{ft}^{2} \\
\text { Number of Compartments : } & 16 \\
\text { Bag Material: } & \text { Fiberglass }\end{array}$ & $\begin{array}{l}\text { Baghouse collectors of this capacity are custom } \\
\text { designed and fabricated. } \\
\text { The baghouse is equipped with an explosion detec- } \\
\text { tion and suppression system. } \\
\text { The baghouse systems include coal collection bins } \\
\text { and interconnecting mass flow conveyors. }\end{array}$ \\
\hline 6 & $\begin{array}{l}\text { Fluid Bed Dryer Induced Draft } \\
\text { Fan }\end{array}$ & $\begin{array}{l}\text { Included in } \\
\text { Fluid Bed } \\
\text { Dryer Power }\end{array}$ & $\begin{array}{l}\text { Design Capacity: } \\
\text { Static Pressure: }\end{array}$ & $\begin{array}{l}\text { Fans of this capacity and head are used in power } \\
\text { plants for flue gas. }\end{array}$ \\
\hline 2 & $\begin{array}{l}\text { Coal Dryer Discharge } \\
\text { Conveyor }\end{array}$ & 300 & Design Capacity: & See General Conveyor Specification. \\
\hline 1 & $\begin{array}{l}\text { Coal Dryer Surge Bin } \\
\text { Baghouse Dust Collection } \\
\text { System }\end{array}$ & 60 & Design Capacity: & Standard Baghouse System. \\
\hline
\end{tabular}


THIS PAGE

\section{WAS INTENTIONALLY LEFT BLANK}




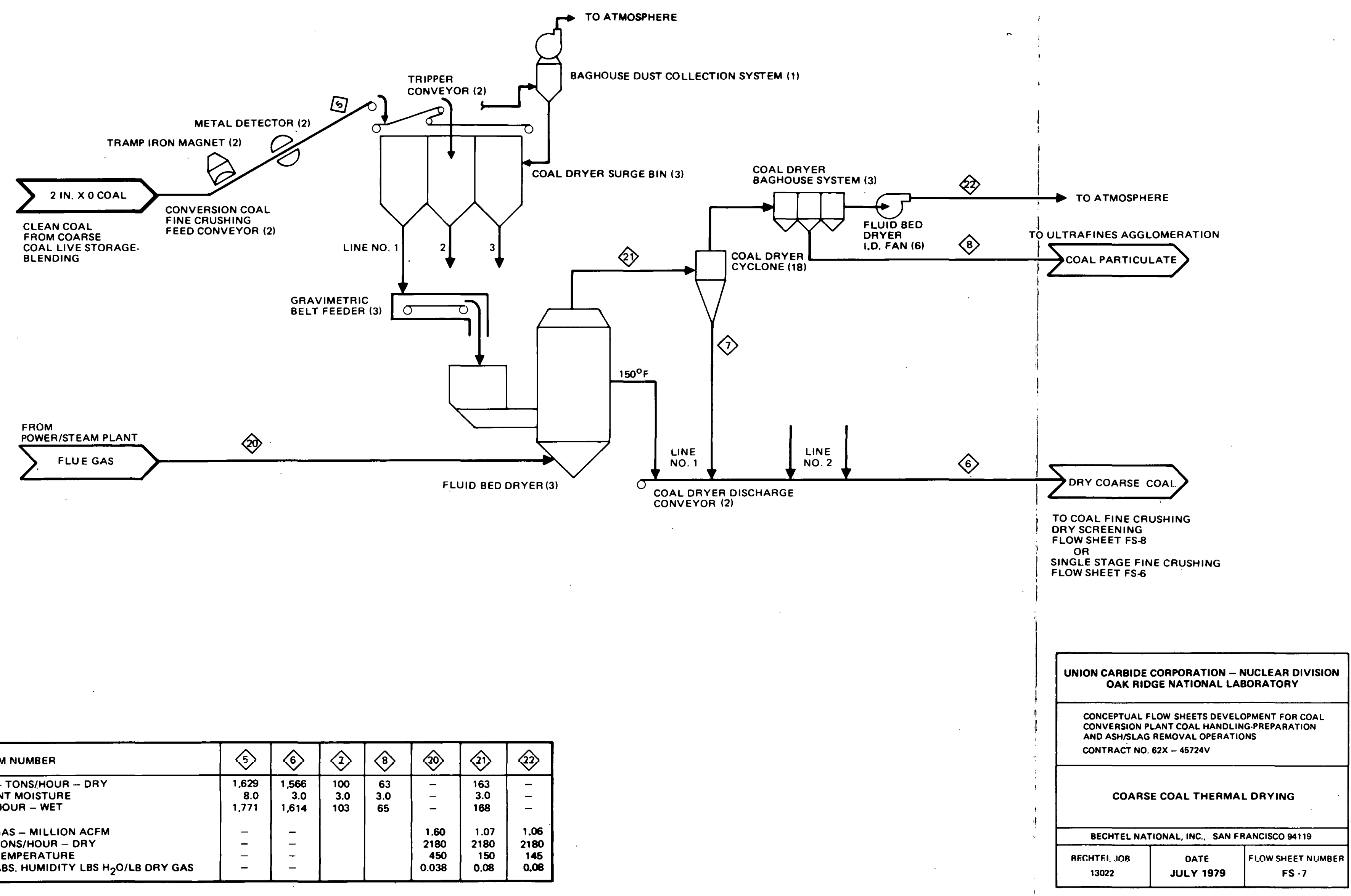


THIS PAGE

\section{WAS INTENTIONALLY \\ LEFT BLANK}




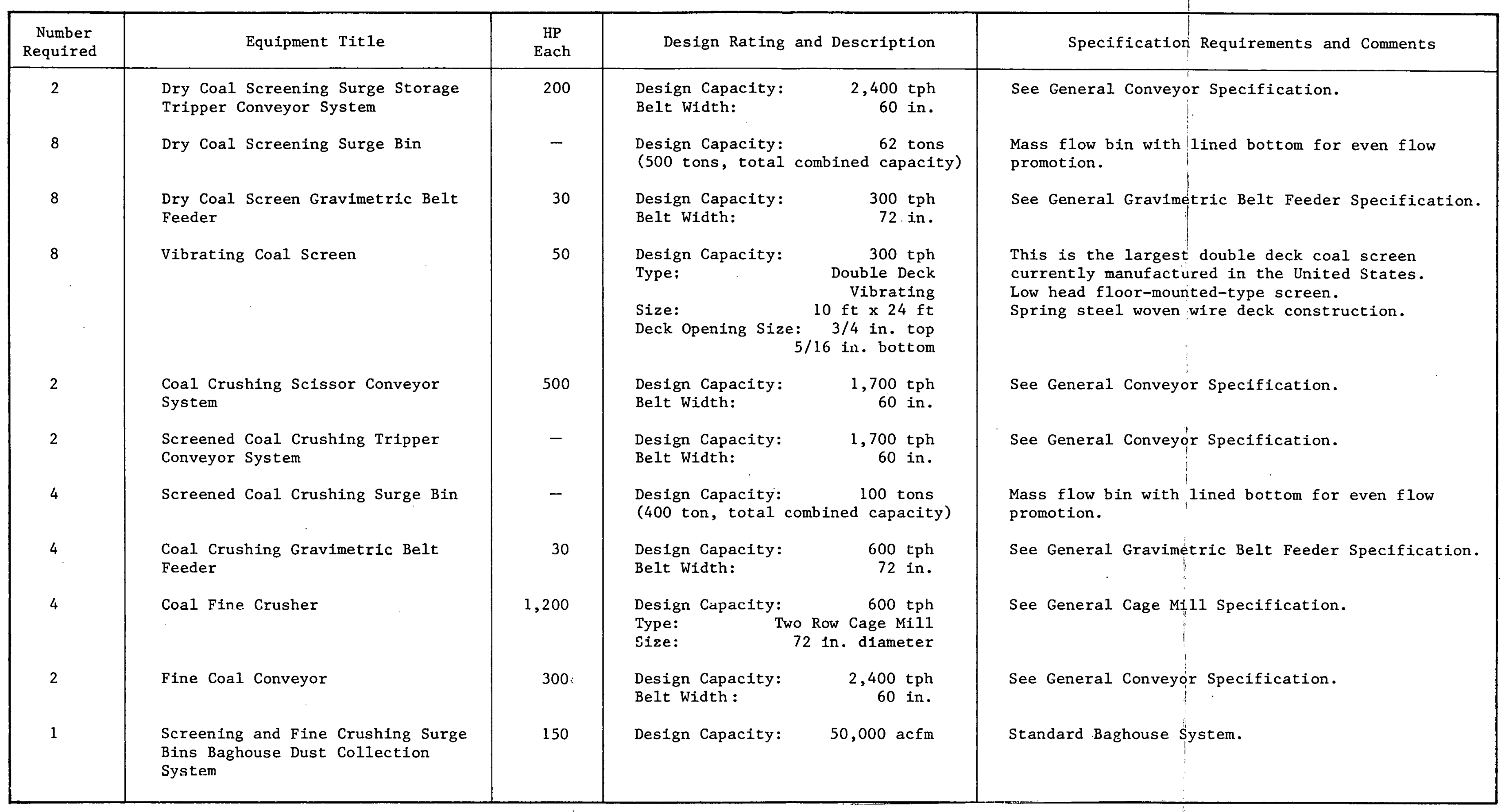


THIS PAGE

WAS INTENTIONALLY

LEFT BLANK 


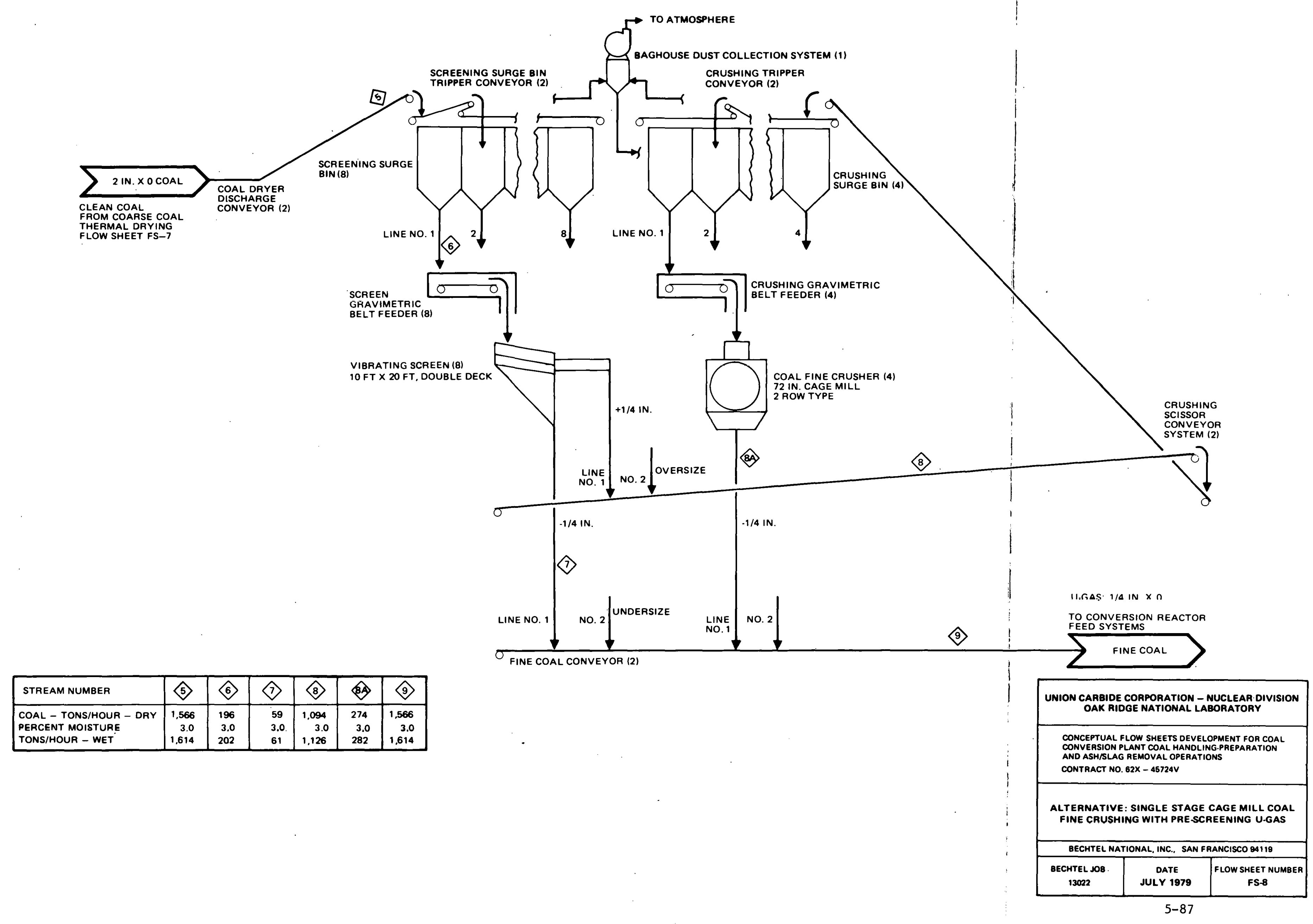




\section{THIS PAGE . \\ WAS INTENTIONALLY \\ LEFT BLANK}


Dry coal screening at $1 / 4$ inch represents an approximate practical lower size limit and requires relatively dry coal. Because of this, FS-8 was only considered as a possible ultrafines minimization approach for U-Gas and the coal entering FS-8 was specified as coming from FS 7 , Coarse Coal Thermal Drying. Screening of coal at sizes finer than $1 / 4$ inch results in rapidly decreased screen loadings, i.e., the screen area required increases rapidly.' Also, the amount of coal surface moisture that can be tolerated without deterioration of screen efficiency becomes increasingly smaller. Coal surface moistures on the order of several percent are sufficient to blind fine dry screens.

The Texaco Partial Oxidation Gasification Process uses a coal feed system in which a high solids concentration coal-water slurry is injected by positive displacement pumps into an entrained flow gasifier. Gasifier operating pressure is $500-1,500$ psig depending on synthesis gas requirements and coal composition. To produce feed slurry for their gasifier Texaco has proposed rod mill wet grinding. (Because of rod mill use the term grinding is used even though the coal size consist produced fits the definition of coal fine crushing established in this report. This usage is consistent with current mineral beneficiation industry terminology.)

FS-10 is a possible Texaco Partial oxidation wet grinding or fine crushing flow sheet. Coarse coal, 2 inch $\times 0$, after surge storage is ground to 100 percent minus 20 mesh in wet rod mills in open circuit. Water is slurried with coal fed to the mills to produce a slurry containing $60 \mathrm{wt}$ percent coal. Thirteen, 14-1/2 foot-diameter by 20-foot-1ong rod mills are specified to grind 1,771 tons per hour of coarse coal. These rod mills were specified using an estimated power consumption of $10 \mathrm{hp} / \mathrm{hr}$-ton of coal feed.

The reason for spec1ficarlon of rod mills rather than ball mills in f'S-lu is that they produce a narrower size range product. They produce very 
little oversize and few ultrafines. A disadvantage of rod mills and the reason so many are specified is that they are capacity limited. Due to the unavailability of rods that will perform properly in large rod mills their length is limited to approximately 20 feet. Rods longer than this will not stay straight during grinding and break into pieces that are discharged from the mill as large chunks. The largest rod mills currently installed are 15 feet in diameter.

\subsubsection{Coal Fine Crushing With Ultrafines Removal}

As indicated in Subsection 4.3.3, a conceptual fine coal ultrafines separation flow sheet was developed. This flow sheet is presented in FS-9. It could be used with any of the other fine crushing flow sheets provided the crushed coal is sufficiently dry. The FS-10 plant design material balance is a continuation of that presented in FS-3 for SRC-I and II feed coal crushing. Crushed ultrafines separation feed coal total moisture is 8.0 wt percent.

In FS-9 fine coal is conveyed to a series of surge bins. From each bin it is fed by a gravimetric belt feeder to an air classifier. These air classifiers are similar to those described in FS-5, Cage Mill Closed-Circuit coal Fine crushing. The main difference is that hot flue gas (450 $0^{\circ}$ ) from the power/steam plant is injected into the ultrafines classifiers to reduce coal moisture. Ultrafine coal is discharged from each classifier at two locations: the classifier fines cone and entrained in exiting dry flue gas. Ultrafines collected in the tines cone are discharged by rotary lock valves to one of two mass flow conveyors. Ultrafines entrained in the drying flue gas are removed by cyclones in series with multicompartment baghouses. Collected coal from both the cyclones and baghouses are discharged to the same mass flow conveyors as ultrafines collected in thic ilisifier fines cones. 
MAJOR EQUIPMENT LIST

\begin{tabular}{|c|c|c|c|c|}
\hline $\begin{array}{l}\text { Number } \\
\text { Required }\end{array}$ & Equipment Title & $\begin{array}{c}\text { HP } \\
\text { Each }\end{array}$ & Design Rating and Description & Spectification Requirements and Comments \\
\hline 2 & $\begin{array}{l}\text { Ultrafines Separation Surge } \\
\text { Storage Tripper Conveyor System }\end{array}$ & 150 & $\begin{array}{lr}\text { Design Capacity: } & 2,400 \mathrm{tph} \\
\text { Belt Width: } & 60 \mathrm{in} .\end{array}$ & See General Conveyor Specification. \\
\hline 6 & U1trafines Separation Surge Bin & - & $\begin{array}{l}\text { Design Capacity: } 300 \text { tons } \\
(1,800 \text { tons, total combined } \\
\text { capacity) }\end{array}$ & $\begin{array}{l}\text { Mass flow bin with lined bottom for even flow } \\
\text { promotion. }\end{array}$ \\
\hline 6 & $\begin{array}{l}\text { Air Classifier Gravimetric Belt } \\
\text { Feeder }\end{array}$ & 30 & $\begin{array}{l}\text { Design Capacity: } \\
\text { Belt Width: }\end{array}$ & See General Gravimetric Belt Feeder Specification. \\
\hline 6 & Crushed Coal Air Classifier & 500 & $\begin{array}{l}\text { Design Capacity: } \quad 400 \mathrm{tph} \\
\text { Type: Mechanical Centrifugal } \\
\cdot \quad \text { Air Classifier with } \\
\text { Size: } \quad \text { Drying Gas Injection } \\
\quad 22 \mathrm{ft} \text { diameter }\end{array}$ & $\begin{array}{l}\text { Air Classifiers of up to } 24 \mathrm{ft} \text { in diameter are } \\
\text { currently used for closed-circuit cement grinding. } \\
\text { Hot flue gas is added to control coal surface } \\
\text { moisture for efficient classification. } \\
\text { Abrasion resistant steel lined. }\end{array}$ \\
\hline 24 & $\begin{array}{l}\text { Ai.r. Classifier Exhaust Gas } \\
\text { Cyclone }\end{array}$ & - & $\begin{array}{l}\text { Design Capacity: } 20,000 \text { acfm } \\
\text { Type: Centrifugal Gas Cyclone } \\
\text { Number of Cyclone Clusters: } 6 \\
\text { Size: } \quad 6 \mathrm{ft} \text { diameter }\end{array}$ & $\begin{array}{l}\text { Cyclones of this size are of standard design and } \\
\text { are widely used for gas particulate separation. } \\
\text { Cyclones are manifolded together in clusters of } \\
\text { four cyclones which have a common underflow bin. } \\
\text { Abrasion resistant steel lined }\end{array}$ \\
\hline 3 & $\begin{array}{l}\text { Particulate Coal Collection } \\
\text { System Multi-Compartment } \\
\text { Baghouse }\end{array}$ & 60 & $\begin{array}{l}\text { Design Capacity: } 200,000 \text { acfm } \\
\text { Number of Compartments: } 6 \\
\text { Design Pressure Drop: } 8 \text { in. } \mathrm{H}_{2} \mathrm{O} \\
\text { Area: } \quad 120,000 \mathrm{ft}^{2} \\
\text { Bag Material: } \quad \text { Fiberglass }\end{array}$ & $\begin{array}{l}\text { Baghouse collectors of this capacity are custom } \\
\text { designed and fabricated. } \\
\text { The baghouse is equipped with an explosion detec- } \\
\text { tion and suppression system. } \\
\text { The baghouse systems include coal collection bins } \\
\text { and interconnecting mass flow conveyors. }\end{array}$ \\
\hline 3 & Baghouse Induced Draft Fan & 1,000 & $\begin{array}{l}\text { Design Capacity: } 200,000 \text { acfm } \\
\text { Design Head: } \quad 30 \text { in. } \mathrm{H}_{2} \mathrm{O} \\
\text { Design Temperature: } \quad 180^{\circ} \mathrm{F}\end{array}$ & Standard Design Flue Gas Fan. \\
\hline 2 & U1trafines Mass Flow Conveyor & 300 & $\begin{array}{lr}\text { Design Capacity: } & 600 \mathrm{tph} \\
\text { Type: Chainflight mass flow } \\
\text { Width: } & 40 \mathrm{in} .\end{array}$ & $\begin{array}{l}\text { This type of totaliy enclosed conveyor has not been } \\
\text { demonstrated on ultrafine coal. } \\
\text { Equipment development may be required. }\end{array}$ \\
\hline 2 & Fine Coal Conveyor & 300 & $\begin{array}{l}\text { Design Capacity: } \\
\text { Width: }\end{array}$ & See General Conveyor Specification. \\
\hline 1 & $\begin{array}{l}\text { Ultrafines Surge Bins Baghouse } \\
\text { Dust Collection System }\end{array}$ & 150 & Design Capacity: 50,000 acfm & Standard Baghouse System. \\
\hline
\end{tabular}




\section{THIS PAGE \\ WAS INTENTIONALLY \\ LEFT BLANK}


THIS PAGE

\section{WAS INTENTIONALLY LEFT BLANK}


MAJOR EQUIPMENT LIST ROD MILL COAL WET GRINDINC FLOW SHEET FS-10

\begin{tabular}{|c|c|c|c|c|}
\hline $\begin{array}{l}\text { Number } \\
\text { Required }\end{array}$ & Equipment Title & $\begin{array}{l}\mathrm{HP} \\
\text { Each }\end{array}$ & Design Rating and Description & Specification Requirements and Comments \\
\hline 2 & $\begin{array}{l}\text { Grinding Surge Storage Tripper } \\
\text { Conveyor System }\end{array}$ & 200 & $\begin{array}{lr}\text { Design Capacity: } & 2,400 \mathrm{tph} \\
\text { Belt Width: } & 60 \mathrm{in} .\end{array}$ & See General Conveyor Specification. \\
\hline 13 & Grinding Surge Bin & - & $\begin{array}{l}\text { Design Capacity: } 140 \text { tons } \\
(1,800 \text { tons, total combined capacity })\end{array}$ & $\begin{array}{l}\text { Mass flow bin with lined bottom for even } \\
\text { flow promotion. }\end{array}$ \\
\hline 13 & $\begin{array}{l}\text { Rod Mill Gravimetric Belt } \\
\text { Feeder }\end{array}$ & 20 & $\begin{array}{l}\text { Design Capacity: } \\
\text { Belt Width: }\end{array}$ & See General Gravimetric Belt Feeder Specification. \\
\hline 13 & Coal Grinding Rod Mill & 1,800 & 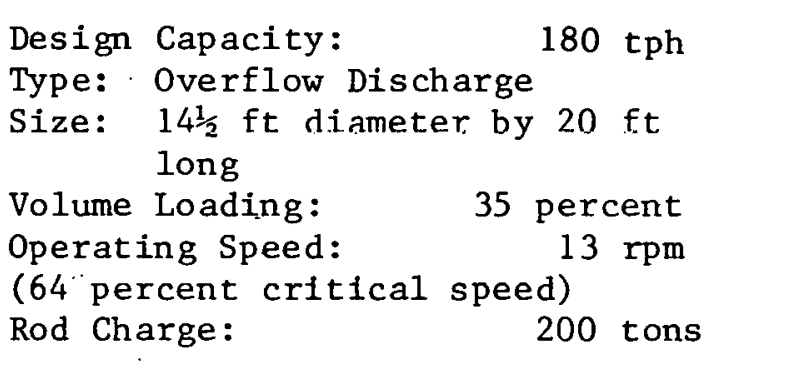 & $\begin{array}{l}\text { Wet rod mills of this size are currently used } \\
\text { for ore and coal grinding. } \\
20 \mathrm{ft} \text { is an approximate maximum length for a } \\
\text { rod mill. }\end{array}$ \\
\hline 13 & Rod Mill Discharge Sump & - & Design Capacity: $\quad 200 \mathrm{ft}^{3}$ & Concrete Construction Sump. \\
\hline 13 & Rod Mill Discharge Pump & 40 & $\begin{array}{lr}\text { Design Capacity: } & 1,000 \mathrm{gpm} \\
\text { Design Head: } & 50 \mathrm{ft} \\
\text { Type: Horizontal centrifugal. }\end{array}$ & Construction: Ni-Hard Impeller and Casing. \\
\hline 1 & $\begin{array}{l}\text { Grinding Surge Bins Baghouse } \\
\text { Dust Collection System }\end{array}$ & 150 & Design Capacity: & Standard Baghouse System. \\
\hline
\end{tabular}


THIS PAGE

\section{WAS INTENTIONALLY \\ LEFT BLANK}




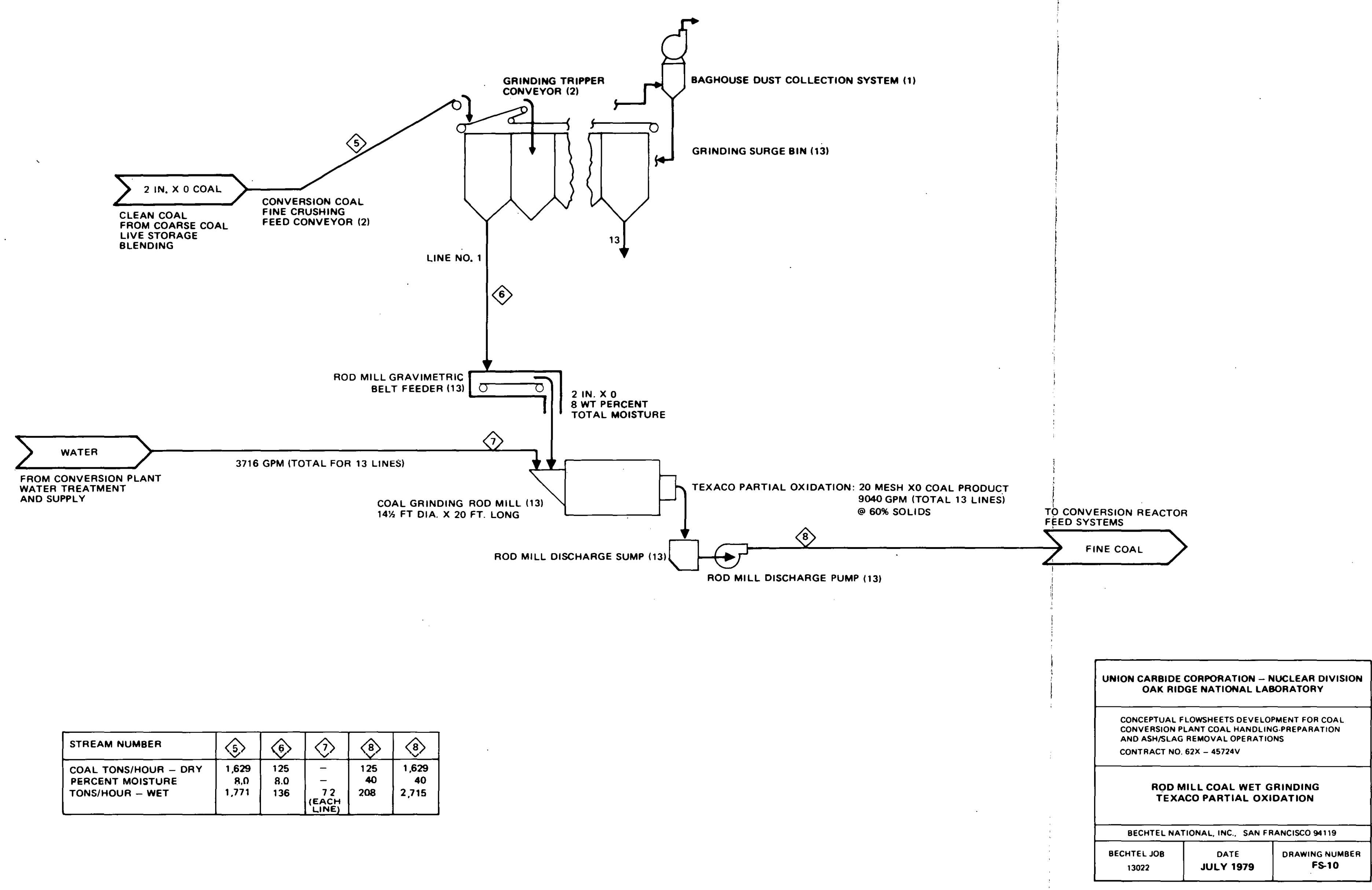


THIS PAGE

\section{WAS INTENTIONALLY \\ LEFT BLANK}


Ultrafines free coal is discharged from the air classifiers by rotary lock valves and flow switching chutes to one of two fine coal conveyors. These conveyors convey it to conversion reactor coal feed systems.

Reliable and efficient operation of air (gas) classifiers is very dependent on feed coal surface moisture. How much moisture is acceptable depends on the coal, classifier feed size consist, and separation particle size. By hot flue gas injection both Pittsburgh and Kentucky No. 9 Seam coals can probably be successfully classified at feed sizes down to 100 percent minus 20 mesh; the finest crushed coal size consist considered. Actual quantities of drying flue gas required and classifier internals design would for actual classification facilities be determined by testing. The material balance values presented in FS-9 are only estimated values.

Depending on feed coal size consist a different number of classification trains than the six shown in FS-9 could be required. The number of trains also depends on the ultrafines size. For development of FS-9, ultrafines coal was defined to be coal containing particles all 100 mesh or finer.

In assessing flow sheet FS-9 it should be recognized that, as far as could be determined, dry coal classification at the sizes and capacities that would be required for conversion coal ultrafines removal has never been commercially practiced. Large-scale fine particulates classification is, however, used for production of other materials, notably cement. This technology, totally or partially, may be adaptable to large-scale coal classification if it is required.

If fine coal ultrafines removal is required or justified for a specific conversion process, something must be done with the ultrafines.. Consideration of processes for treating ultrafines, however, was not part of the undertaking covered by this project. Possible ultrafines uses include: 
- Direct firing in pulverized coal-fired steam generators

- Possible firing in fluidized-bed steam generators by injection of ultrafines into the bottom of the fluidized bed by entraining them in the fluidizing air

- Agglomeration followed by combustion in a fluidized-bed steam generator or feeding to a conversion reactor

Ultrafines could be agglomerated by either briquetting or pelletizing. Briquetting with a binder would probably be used if a high strength agglomerate is required. Coal briquetting technology is well developed, but is expensive. Conversion of agglomerated coal in any of the conversion reactors identified in Table 4-1 has, as far as known, never been tested. Coal briquetts have, however, been successfully gasified in fixed bed gasifiers.

In addition to ultrafines utilization, another potential problem that could be associated with ultrafines removal is their transport. Both ultrafines size consist and explosion characteristics complicates their transport. In FS-9 mass flow conveyors are specified for ultrafines transport. This type of conveyor has been successfully used to transport very fine, hazardous solids and can be designed to minimize air infiltration. However, they have never been used to transport large quantities of ultrafine. coal. And, development/demonstration would be required before actual use of mass flow conveyors. This is particularly true if ultrafines require significant elevation as part of their transport.

Other transport alternatives that could be considered for coal ultrafincs includc:

- Dilute phase transport in inert gas

$\dot{0}$ Dense phase transport in inert gas

- Screw conveyors

- Water or other fluid slurry transport if compatible with ultrafines utilization 
5.5 COAL PULVERIZING AND GRINDING CONCEPTUAL FLOW SHEETS

As reviewed in Subsection 4.3.4, there are two ways of producing pulverized or ground coal as reportedly required by H-Coal: "dry pulverizing and liquefaction solvent grinding. This subsection presents a conceptual flow sheet for the latter alternative. Conceptual flow sheets, material and enthalpy balances, and major equipment lists for two drying-pulverizing alternatives are presented in the coal mine-coal conversion plant interface evaluation and conceptual design project final report (1).

The two coal pulverizing alternatives presented in the coal mine-coal conversion plant interface final report are: ball tube mill and roller mill coal pulverizing. In both alternatives large quantities of hot flue gas $\left(450^{\circ} \mathrm{F}\right)$ from the power/steam plant are used to transport coal through the mills and simultaneously dry it from as received to $2.0 \mathrm{wt}$ percent total moisture. After pulverizing to 70 percent minus 200 mesh, coal is deentrained from the conveying-drying flue gas in cyclone clusters in series with large, multicompartment baghouses. Specific interface report flow sheets and conceptual drawings concerned with coal pulverizing and pulverized coal separation are:

- Conversion reactor coal pulverizing ball tube mill flow sheet: PFD-5 (Volume 1)

- Gas flow schematic - ball tube mill system: Figure 5-9 (Volume 1)

- Conversion rcaçtor coal pulverizing rniler mill flow sheet: PFD-6 (Volume 1)

- Gas flow schematic-roller mill system: Figure 5-10 (Volume 1)

- Ball tube mill coal pulverizing/separation facility description, major equipment 1ist, and conceptual design drawings: (Section 11.1 (Volume 2)

- Roller mill coal pulverizlng/separation facility description, major equipment list, and conceptual design drawings: Section 11.2 (Volume 2) 
Both the ball tube and roller mills specified in the interface pulverizing flow sheets are rated at 250 tons per hour of feed coal. To date, the largest coal ball tube mill is rated at approximately 80 tons per hour and the largest coal roller mill at approximately 100 tons per hour. Scale up of both mill designs to the 250 ton per hour range judged required for commercial coal conversion plants does appear technically feasible. This conclusion is based on discussions with major, large coal mill designer-manufacturers; Bechtel experience with dry coal mills for the utility industry and large wet and dry mille for the metals industry; and, reported experience with large dry mills in the cement inductry. Certain design areas, pallicularly mill drive systems, will, however, require additional development and demonstration. To date there has been no incentive to develop coal mills larger than 100 tons/hour. This, rather than technical reasons, is why larger coal mills have not been built.

Pulverized coal produced by both interface report flow sheets would have to be transported from the cyclones and baghouses used to deentrain it from mill system transport drying flue gas to the H-Coal coal feed system. Comments in Subsection 5.4 .2 concerning ultrafine coal transport alco apply to the 70 percent minus 200 mesh, dried roal produced by these flow sheets. However, in the case of H-Coal the pulverized conal transport distances could probably be kept short and the need for excessive coal. elevation avoided.

FS-11 presents a conceptual flow sheet for grinding of coal in liquefaction process recycle solvent. In order to meet the H-Coal Process feed coal moisture requirement, coal fed to FS-11 is shown as first being dried in F's-/, Coarse Coal Thermal Drying. If grinding recycle solvent is sufficiently hot this drying may not be required. However, use of solvent heat for simullaneuus coal drying-grinding would require a steam flash separation following grinding. 


\begin{tabular}{|c|c|c|c|c|}
\hline $\begin{array}{l}\text { Number } \\
\text { Required }\end{array}$ & Equipment Title & $\begin{array}{c}\mathrm{HP} \\
\text { Each }\end{array}$ & Design Rating and Description & Specification Requirements and Comments \\
\hline 2 & $\begin{array}{l}\text { Coal Grinding Surge Storage Tripper } \\
\text { Conveyor System }\end{array}$ & 200 & $\begin{array}{lr}\text { Design Capacity: } & 2,400 \mathrm{tph} \\
\text { Belt Width: } & 60 \mathrm{in} .\end{array}$ & See General Conveyor Specification. \\
\hline 9 & Coal Grinding Surge Bin & - & $\begin{array}{lc}\text { Design Capacity: } & 200 \text { tons } \\
(1,800 \text { tons, total combined capacity })\end{array}$ & $\begin{array}{l}\text { Mass flow bin with lined bottom for even flow } \\
\text { promotion. }\end{array}$ \\
\hline 9 & $\begin{array}{l}\text { Coal Grinding Gravimetric Belt } \\
\text { Feeder }\end{array}$ & 30 & $\begin{array}{l}\text { Design Capacity: } \\
\text { Belt Width: }\end{array}$ & See General Gravimetric Belt Feeder Specification. \\
\hline y & Coarse Coal Crusher & 800 & $\begin{array}{ll}\text { Design Capacity: } & 300 \mathrm{tph} \\
\text { Type: } & 2 \text { Row Cage Mill } \\
\text { Size: } & 72 \text { in. diameter }\end{array}$ & See General Cage Mill Specification. \\
\hline 9 & Crushed Coal Screw Conveyor & 40 & $\begin{array}{ll}\text { Design Capacity: } & 300 \mathrm{tph} \\
\text { Type: Double Helicoid Flights } \\
\text { Flight Diameter: } & 10 \text { in. }\end{array}$ & $\begin{array}{l}\text { Screw Conveyors of this capacity are standard } \\
\text { equipment. }\end{array}$ \\
\hline 9 & Coal Ball Mill & 6,000 & $\begin{array}{lr}\text { Design Capacity: } & 300 \mathrm{tph} \\
\text { Type: } & \text { Overflow Discharge } \\
\text { Size: } & 18 \mathrm{ft} \text { diameter by } \\
& 28 \frac{1}{2} \mathrm{ft} \text { long } \\
\text { Volume Loading: } & 40 \text { percent } \\
\text { Operating Speed: } & 13 \mathrm{rpm} \\
\text { (68.7 percent critical speed) } \\
\text { Ball Charge: } & 393 \text { tons }\end{array}$ & $\begin{array}{l}\text { Wet ball mills of this size are currently used for } \\
\text { ore grinding, but not coal. } \\
\text { Solvent coal grinding has yet to be demonstrated. } \\
\text { Mill system vapor scaling is an area where devel- } \\
\text { opment is required. }\end{array}$ \\
\hline 9 & Ball Mill Discharge Sump & - & $\begin{array}{lr}\text { Design Capacity: } & 300 \mathrm{ft}^{3} \\
\text { Construction: } & \text { Concrete }\end{array}$ & This sump would require a vapor control system. \\
\hline 9 & Ball Mill Discharge Pump & 75 & $\begin{array}{l}\text { Design Capacity: } \quad 1,800 \mathrm{gpm} \\
\text { Type: Horizontal Centrifugal } \\
\text { Construction: Ni-Hard Impeller } \\
\quad \text { and Casing }\end{array}$ & $\begin{array}{l}\text { Pumps for handling of pulverized coal-solvent } \\
\text { slurry are being developed as part of coal con- } \\
\text { version process development and demonstration } \\
\text { projects. }\end{array}$ \\
\hline 1 & $\begin{array}{l}\text { Coal Grinding Surge Bins Dust } \\
\text { Collection System }\end{array}$ & 60 & Design Capacity: & Standard Baghouse System. \\
\hline
\end{tabular}


THIS PAGE

\section{WAS INTENTIONALLY \\ LEFT BLANK}




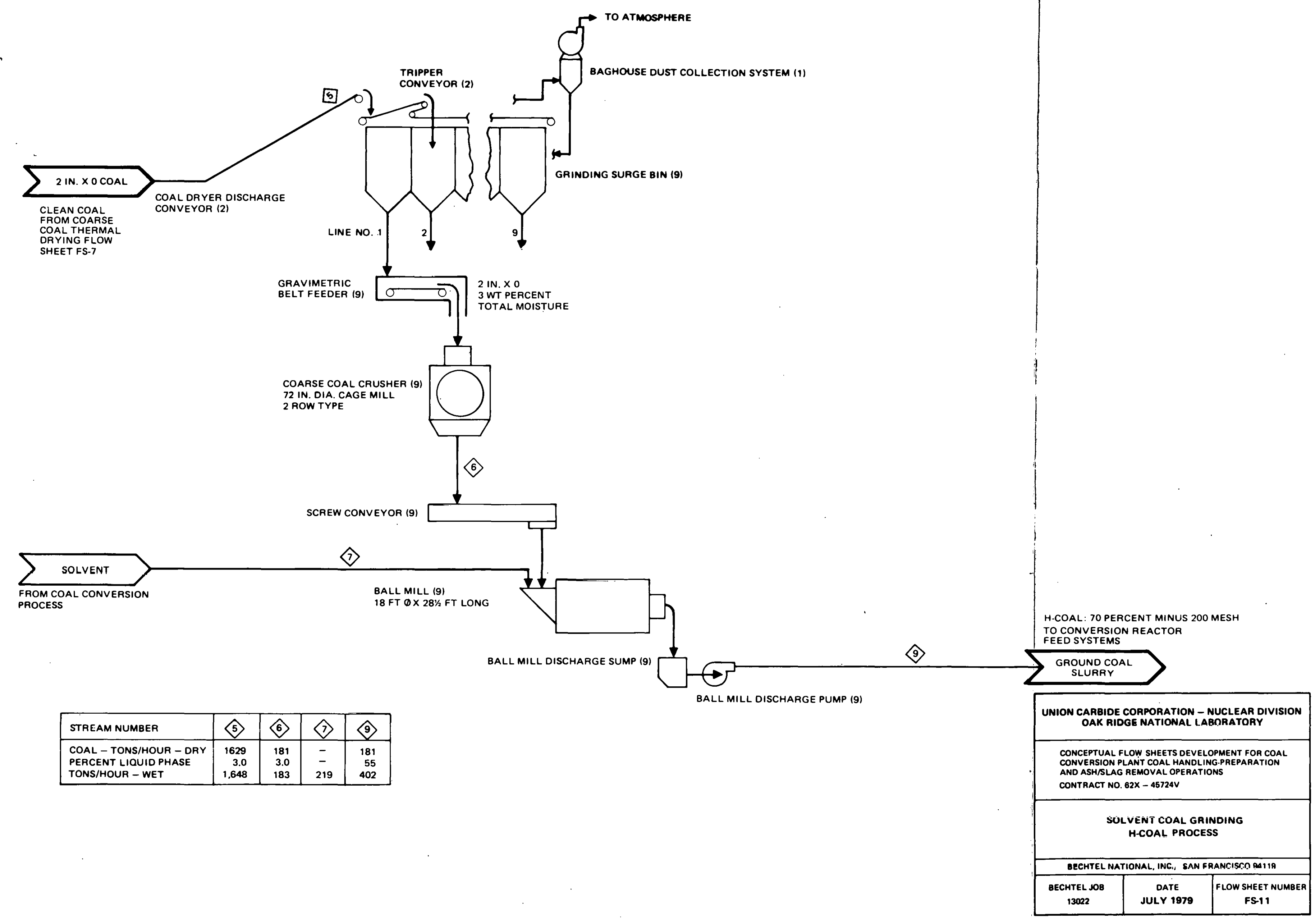

5-105 
THIS PAGE

\section{WAS INTENTIONALLY LEFT BLANK}


In FS-11 dry coal is conveyed by two, parallel, full design capacity conveyors to two, parallel surge storage tripper conveyor systems which discharge it into in-line surge bins. From here it is discharged by gravimetric belt feeders to fine crushing cage-mills. Surge storage, mill feeding, and fine crushing operations are very similar to those described in FS-3, Single-Stage Cage Mill Fine Crushing. Fine crushing is used before grinding to reduce overall comminution power requirement, i.e., power required for the approach shown in FS-11 is considerably less than direct feeding of 2 inch $x$. coal.to a ball mill.

Coal-crushed to nominally $1 / 8$ inch $\mathrm{x} 0$ is discharged from the cage mills. to screw conveyors which convey it to 18 -foot-diameter by $281 / 2$ foot-long ball mills. Estimated installed power requirement for each mill is 6,000 hp. Ball mills of the specified size are currently available commercially. Two copper concentrators, Bougainville in Papua New Guinea and Pinto Valley in Arizona, used 18 foot-diameter ball mills for primary grinding. Use of ore grinding ball mills with diameters in excess of 20 feet and lengths of up to $40 \mathrm{feet}$ is anticipated in the near future. The 6,000 hp mill power specified is slightly higher than that for currently operating ball mills 5,000 hp, but within the capability of current mill drive systems.

Pulverized coal as' a 45 wt percent coal-solvent slurry discharges from the ball mills to sumps. From here it would likely be pumped to high pressure conversion reactor coal-solvent injection pumps.

In FS-11 coal is assumed to be dried before grinding. The material balance feed coal total moisture concentration is 3.0 wt percent; one percentage point more than the $\mathrm{H}$-Coal feed moisture requirement presented in Table 4-1. This difference is not considered significant, but, if required, coarse coal could probably be dried to 2.0 wt percent moisture in FS-7 or a similar drying flow sheet. In the EDS, SRC-1, and SRC-II conversion processes coal 
is dried after solvent slurrying by heating and steam flashing. This drying method could also presumably be used with H-Coal. This would not affect ball mill solvent grinding, i.e., 8.0 wt percent total moisture coal is acceptable ball mill feed.

As stated in Subsection 4.3.4, Kennedy Van Saun Corporation is under a DOE contract performing limited testing of solvent-coal slurry grinding (9). To simulate a coal liquefaction recycle solvent, No. 4 and No. 6 fuel oil are being used in these tests. Test results to date indicate that there may be significant differences between wet grinding of coal in oil and wet grinding of coal in water. One result is llal puwer leyuilemenls appear to be higher for oil grinding. However, much additional research... is required to quantify power requirements and product size distributions in terms of mill design and operation for solvent-coal slurry. grinding.

Grinding of coal in liquefaction process solvent is clearly a new grinding approach whose technical feasibility has yet to be demonstrated. Major potential problems associated with solvent-coal grinding include:

- Contról of cóảl solveñe cemperarure - Must 11quefacllun processes use recycle slurrying solvents that would have to be heated to reduce their viscosity to values suitable for grinding. To prevent excesslve energy loss mill insulation could be required.

- Mill eystem sealing - The entire mill system wolld have to be sealed in order to prevent solvent vapor losses. In additlun lu pussibly irepiesenting product and energy losses, the solvent vapor could contain carcinogenic compounds.

- Mill coal feeding - A system for feeding large quantities of crushed coal to a sealed mill system would have to be demonstrated.

- Coating of balls by a coal-solvent paste that would reduce grinding efficiency. 


\subsection{ASH/SLAG REMOVAL CONCEPTUAL FLOW SHEETS}

As presented in Table 4-2 and Figure 4-8, ash and slag are discharged from conversion reactors in two general forms: as water slurries and as dry solids. These are also the two forms considered for moderate distance, on the order of 5 miles, transport to an ultimate, environmentally acceptable disposal site. That is, transport as low-moisture concentration solids or as a water slurry.

Solids from the SRC-I process represent a special case. Solid waste from this process was postulated to be washed and dried filter cake from pressurized filtration of SRC-1 1iquid. Further, this filter cake was postulated to contain significant amounts of unreacted carbon and liquids that could dissolve or be extracted by water slurrying. Because of these characteristics, only transport as a solid was considered practical for SRC-I solid wastes.

Flow sheet FS-12 presents two ash and slag dewatering alternatives to produce material suitable for transport in trucks, rail cars, or on cross country conveyors. These two alternatives are vacuum filtration and spiral separation. Filtration would be used to dewater fine ash slurries, such as those believed to result from the HYGAS, Exxon Donor Solvent, and Exxon Catalytic Gasification gasifiers. Spiral separators are suited to dewatering only coarse solids, such as granulated slag from the Texaco Partial Oxidation gasifier and COGAS cyclone char combustor, and possibly U-Gas agglomerated ash. Separate material balances are presented for each alternative. The unlettered balance is for ash-water slurry dewatering and the 'A' balance applies to granulated slag slurry dewatering.

As indicated in Table 4-2, ash and slag characteristics for a specific gasifier depends on the material gasified and gasifier operation conditions. Also, for most of the gasifiers, ash/slag characteristics have yet to be quantified. Therefore, the rough estimates of ash and slag characteristics presented in Table 4-11 were used to develop FS-12. 
In FS-12 ash or slag after dewatering is combined with dry solids produced at the power/steam plant. The dry steam generator solids (see Subsection 4.3.5 for estimated composition) would likely be conveyed to the solids mixing operation by some type of pneumatic conveying system. Such systems capable of handling the quantities of steam generator solids estimated for coal conversion are currently available.

Combined gasifier slag or ash and power/steam plant solids are conveyed to a surge storage silo. Depending on gasifier type, slagging or ash pro ducing, estimated feed to surge storage is 367 or 222 tons per hour of wastes. This quantity of dewatered solid wastes plus the larger quantity $(1,200$ tons per hour) of coal cleaning solid refuse would probably be transported to a disposal site by either a closed-circuit, dedicated rail system or a cross country conveyor system. Though technically feasible, trucking would probably not be economically feasible for a transport distance on the order of five miles. A very large fleet of trucks would be required to transport the quantity of solid wastes shown in the two FS-12 material balances.

Loadout for rail transport is shown in FS-12. In the rrnss country conveying alternative, the surge silo feeder would discharge coal directly to the conveyor system. Coal cleaning plant refuse would be discharged onto this conveyor system directly from the coal rleaning plant refufe rnnveyor or intermediate conveyors, if required. Cross country conveyor systems of the capacities required to meet the conditions presented in FS-12 are currently used for moderate distance transport of coal and ore.

FS-13 presents a conceptual flow sheet for slurry transport of gasifier, ash or slag, power/steam plant dry solids, and coal cleaning solid refuse. As in FS-12, two llaterlal balances are presented; one for ash producing gasifiers and one for slagging gasifiers ('A' material balance). Both material balances are based on the gasifiers producing 40 wt percent waste solids slurries: If the ash or granulated slag slurries resulting frum 


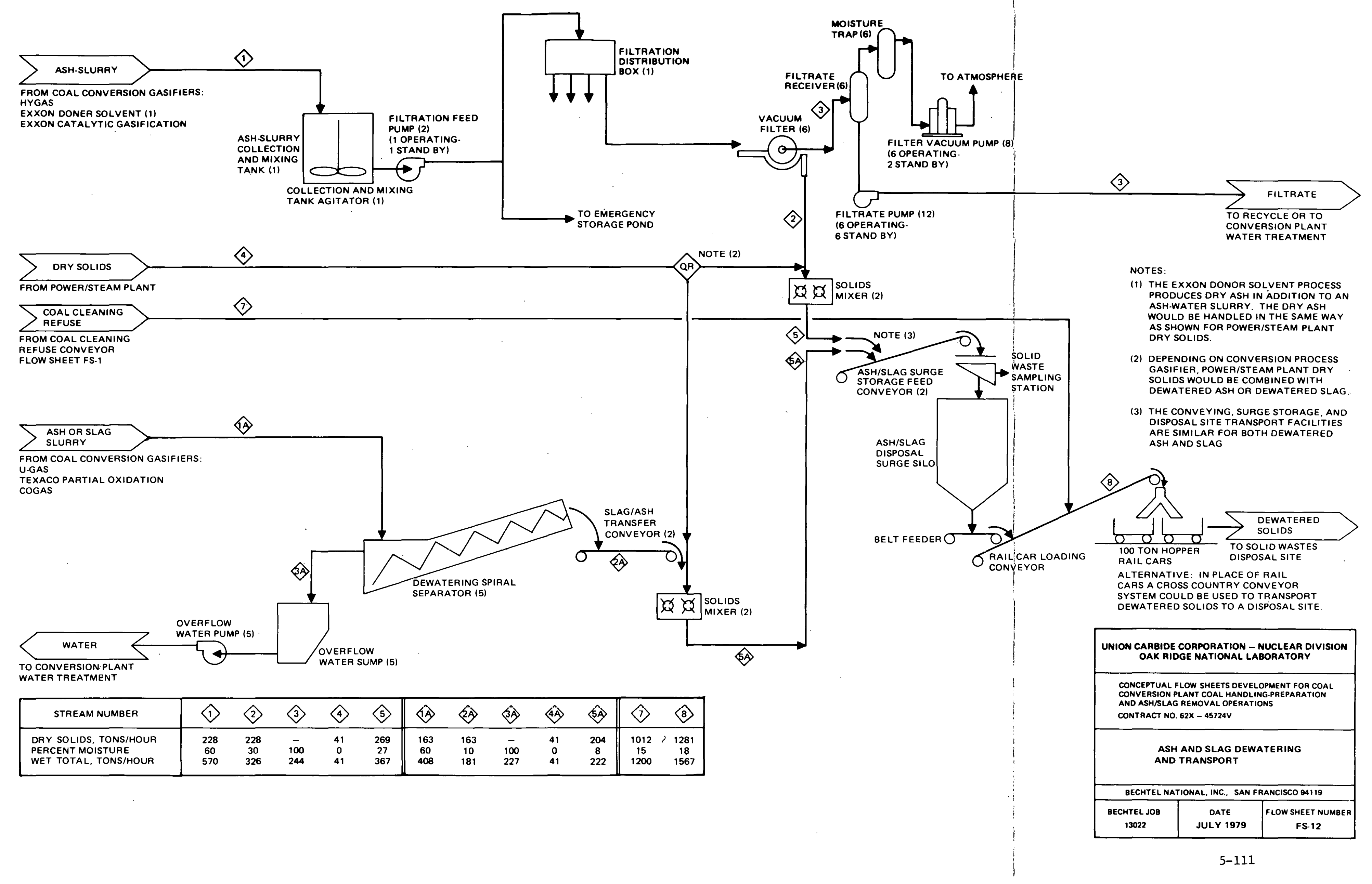


THIS PAGE

\section{WAS INTENTIONALLY \\ LEFT BLANK}


MAJOR EQUIPMENT LIST

ASH AND SLAG DEWATERING AND TRANSPOR? FLOW SHEET $\cdot$ FS- 12

\begin{tabular}{|c|c|c|c|c|}
\hline $\begin{array}{l}\text { Number } \\
\text { Required }\end{array}$ & Equipment Title & $\begin{array}{c}\mathrm{HP} \\
\text { Each }\end{array}$ & Design Rating and Description & Specification Requirements and Comments \\
\hline 1 & $\begin{array}{l}\text { Ash Slurry Collection and } \\
\text { Mixing Tank }\end{array}$ & - & $\begin{array}{lr}\text { ASH SLURRY VACUUM FILTER DEWATERING } \\
\text { Design Capacity: } & 36,000 \mathrm{ga} 1 \\
\text { Effective Volume: } & 4,955 \mathrm{ft}^{3} \\
\text { Overall Dimensions: } & \begin{array}{r}20: \mathrm{ft} \text { diameter } \\
\text { by } 18 \mathrm{ft} \text { high }\end{array}\end{array}$ & $\begin{array}{l}\text { Concrete circular tank - partially covered by floor } \\
\text { for mounting of agitator mechanism and.access }\end{array}$ \\
\hline 1 & $\begin{array}{l}\text { Ash Slurry Collection and Mixing } \\
\text { Tank Agitator }\end{array}$ & 50 & Propeller & Rubber lined shaft and propeller \\
\hline 2 & Filtration Feed Pump & 125 & $\begin{array}{lr}\text { Design Capacity: } & 2,300 \mathrm{gpm} \\
\text { Design Head: } & 100 \mathrm{ft} \\
\text { Type: Horizontal-Centrifugal-Slurry } \\
\text { Slurry Specific Gravity: }\end{array}$ & $\begin{array}{l}\text { Wetted parts to be of NiHard } \\
\text { Two required of which one will be an installed } \\
\text { standby } \\
\text { Slurry pump of this capacity are standard } \\
\text { equipment }\end{array}$ \\
\hline 6 & Ash Vacuum Filter & $\begin{array}{l}20 \\
10\end{array}$ & $\begin{array}{l}\text { Design Capacity: } \quad 46 \mathrm{tph} \text { Solids } \\
\text { Type: } \\
\begin{array}{l}\text { Disc Size: Vacuum Filter } \\
\text { Overall Dimensions: } 12 \mathrm{ft} 6 \text { in. diameter by } \\
\end{array} \quad \begin{array}{l}15 \mathrm{ft} \text { by } 29 \mathrm{ft} \\
\text { by } 14 \mathrm{ft} 6 \text { in. }\end{array}\end{array}$ & $\begin{array}{l}\text { Standard design disc vaccum filter with standard } \\
\text { accessories }\end{array}$ \\
\hline 6 & $\begin{array}{l}\text { Ash Vacuum Filter Filtrate } \\
\text { Receiver }\end{array}$ & - & $\begin{array}{r}\text { Overall Dimensions: } 84 \text { in. diameter } \\
\text { by } 84 \text { in. long }\end{array}$ & Steel construction \\
\hline 12 & $\begin{array}{l}\text { Ash Vacuum Filter Filtrate } \\
\text { Pump }\end{array}$ & 10 & 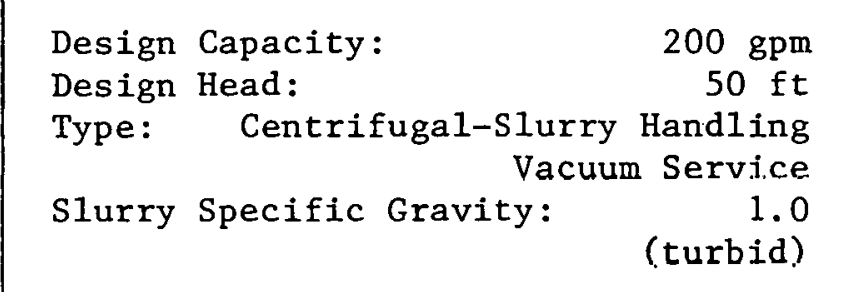 & $\begin{array}{l}\text { Slurry duty - horizontal filter pump } \\
\text { Wetted parts to be NiHard }\end{array}$ \\
\hline 8 & Ash Filter Vacuum Pump & 400 & $\begin{array}{lr}\text { Design Capacity: } & 8,000 \mathrm{cfm} \text { at } \\
& 20 \mathrm{in} . \text { of } \mathrm{Hg} \\
\text { Type: Horizontal-Centrifugal slurry }\end{array}$ & Wet type standard vacuum pump \\
\hline 2 & Solids Mixer & 75 & $\begin{array}{l}\text { Design Capacity: } 500 \mathrm{tph} \\
\text { ASH OR SLAG SPIRAL SEPARATOR DEWATERING }\end{array}$ & $\begin{array}{l}\text { Double-paddle type standard design solids mixer } \\
\text { Several types of solids mixers are available for } \\
\text { this application }\end{array}$ \\
\hline 5 & Dewatering Spiral Separator & 15 & $\begin{array}{lr}\text { Pool Area: } & 200 \mathrm{ft}^{2} \\
\text { Spiral Diameter: } & 60 \mathrm{in} . \\
\text { Tank Slope: } & 31 / 2 \text { in. } / \mathrm{ft} \\
\text { Pitch: } & \text { Double }\end{array}$ & $\begin{array}{l}\text { Standard design steel tank with hydraulic lift } \\
\text { for spiral } \\
\text { Complete with accessories }\end{array}$ \\
\hline
\end{tabular}


THIS PAGE

WAS INTENTIONALLY

LEFT BLANK 


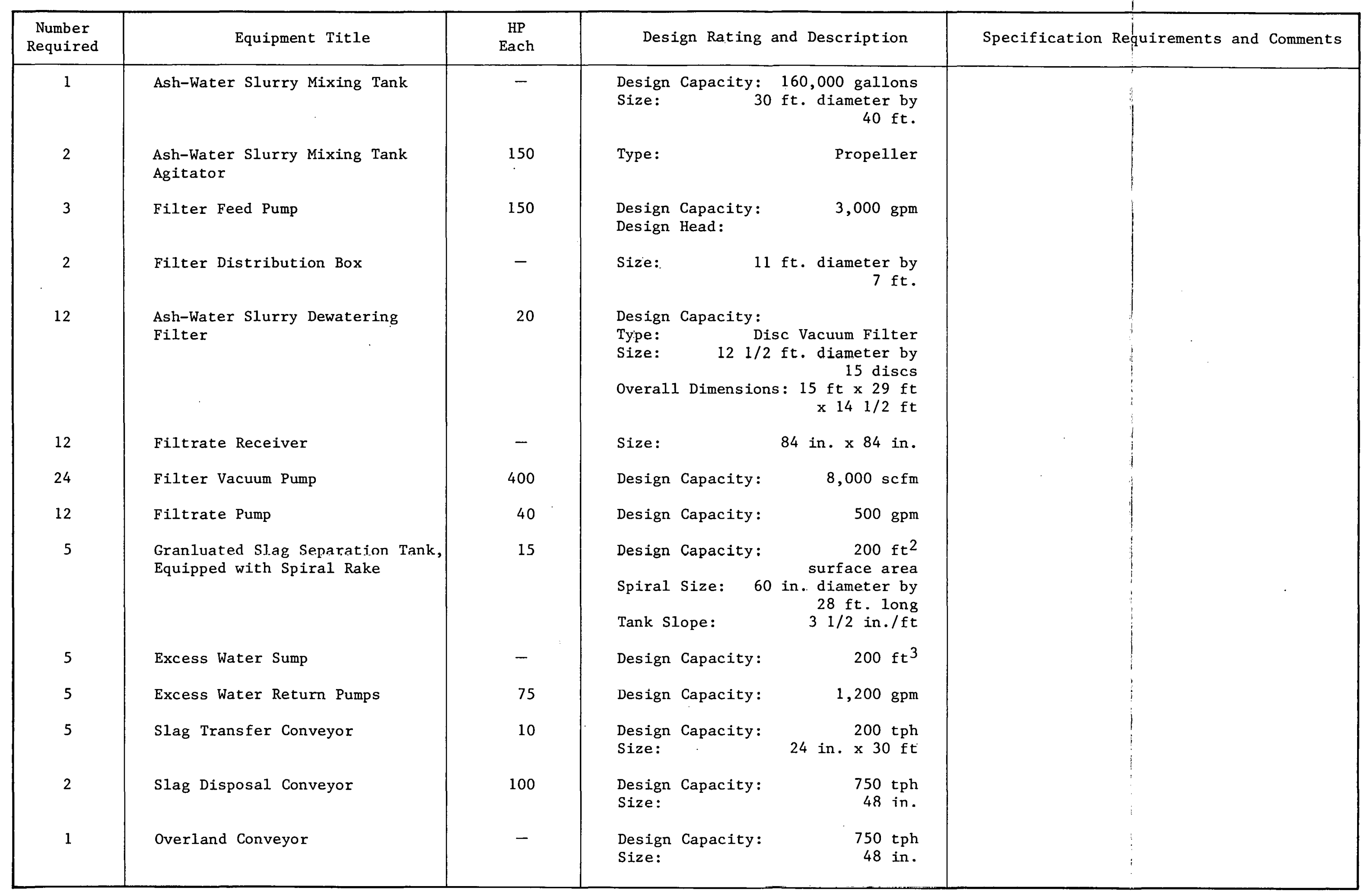


THIS PAGE

\section{WAS INTENTIONALLY \\ LEFT BLANK}




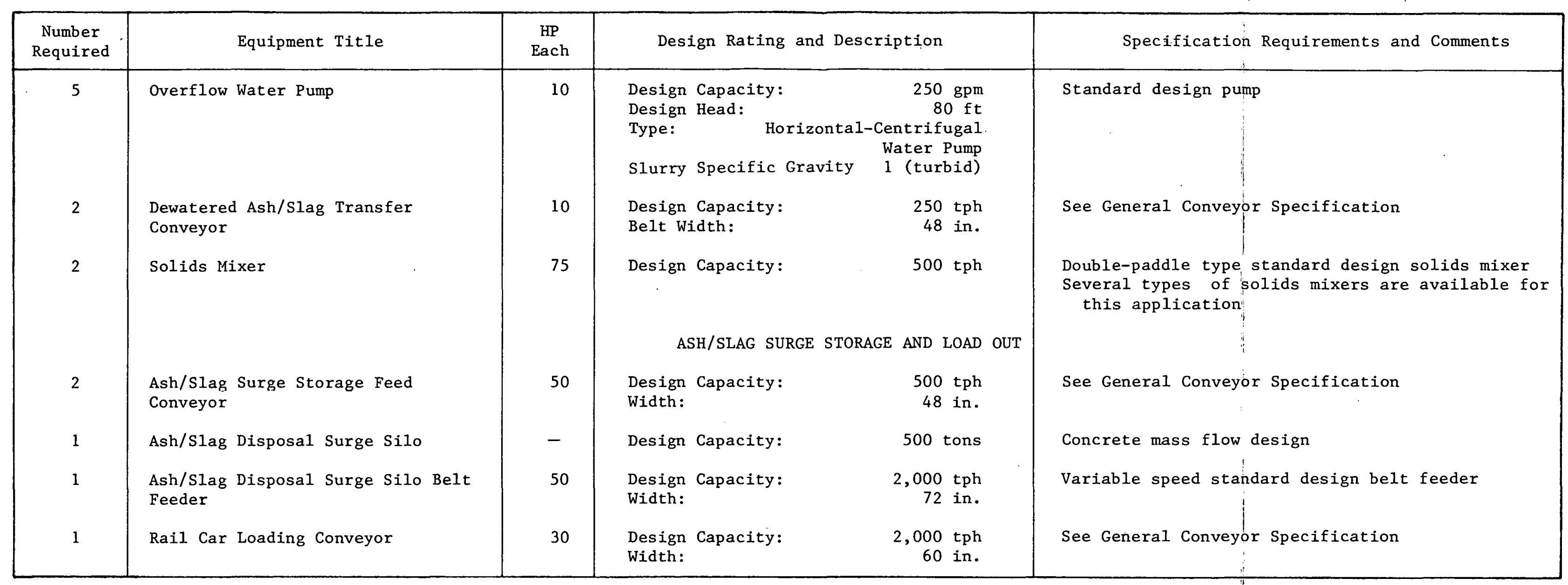


THIS PAGE

WAS INTENTIONALLY

LEFT BLANK 


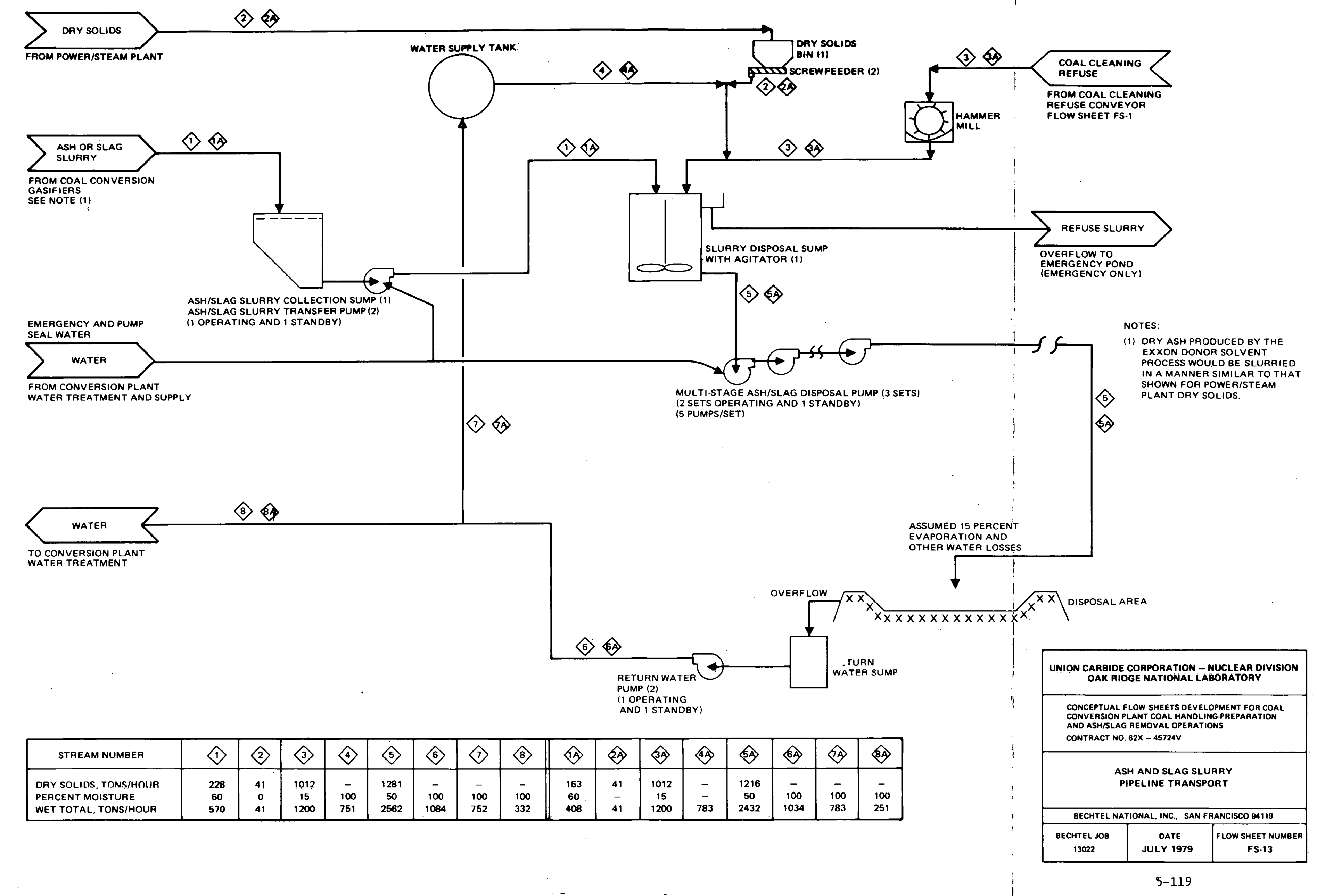


THIS PAGE

WAS INTENTIONALLY

LEFT BLANK 
MAJOR EQUIPMENT LIST

ASH AND SLAG SLURRY PIPELINE TRANSPORT FLOW SHEET FS-13

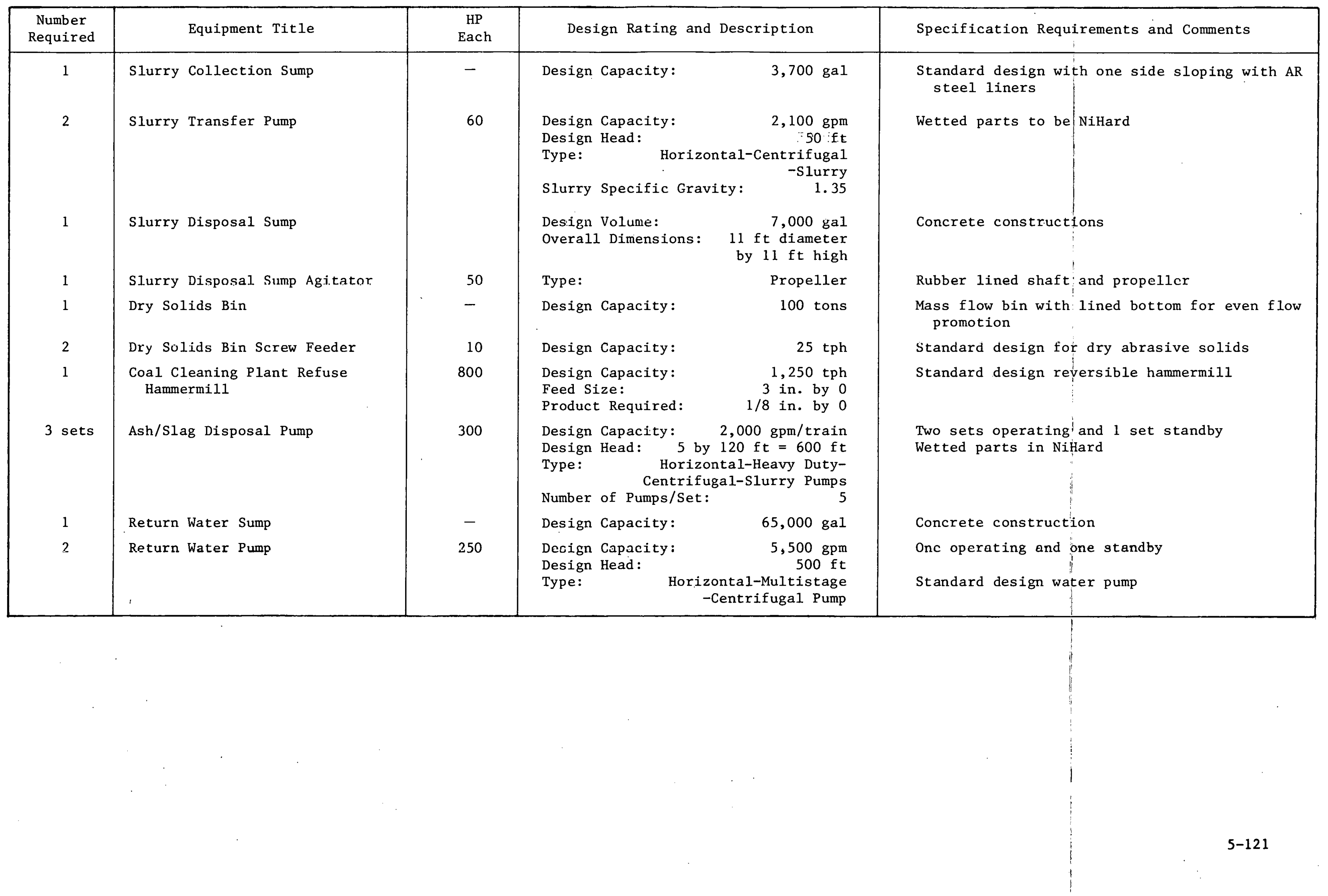


THIS PAGE

\section{WAS INTENTIONALLY LEFT BLANK}


gasification are of significantly lower solids concentration, it could be practical to concentrate them up to $40 \mathrm{wt}$ percent solids or higher. Waste solids could be concentrated by methods similar to those used in FS-12 or by use of thickeners:

The impoundment site shown in FS-13 would probably have to be fully lined with hypalon or similar lining material for impermeability. Decant from this impoundment could be recovered with a barge and floating pipe system. From here it would be returned to the conversion plant water treatment facility or part of it reused directly for solid wastes slurrying.

Slurry pipelines could be advantageous if use of fixing agents is required. Fixing compounds could be added to the FS-13 disposal sump. These compounds would be thoroughly mixed with the solid wastes during pipelining. This fixation approach is currently being used at the 1,760-MW Bruce Mansfield power plant of Ohio Edison for stabilization and disposal of flue gas desulfurization sludge. At the plant site, sludge is mixed with a proprietary stabilizing agent, transported approximately seven miles by pipeline, and deposited at a surface landfill site behind an earthfiil impoundment dam. The treated sludge cures at the disposal site, forming a stabilized landfill mass. Design capacity of the entire Bruce Mansfield sludge slurry disposal system is 21,000 wet tons per day.

Equipment identified in flow sheets FS-12 and FS-13 and their major equipment lists are currently available in the presented design capacities. Areas where additional data would be of value in engineering actual conversion plant solid wastes preparation and transport facilities are:

- Chemical composition and physical properties of conversion processes solid wastes

- Conversion processes solid wastes size constst dala

- Establishment of requirements for environmentally acceptable disposal of conversion processes solid wastes 
- Establishment of fugitive particulates emissions permissible during solid wastes transport

- Investigation of materials for fixing of conversion.processes solid wastes if required to control leaching of harmful compounds 


\subsection{GENERAL}

Cage mills of the capacities specified 'in the major equipment lists would be purchased from a limited number of manufacturers which have provided similar mills. Each manufacturer has his own proven design, parts of which may be protected by patents, and fabrication methods. Provision of mills that depart significantly in design from that used by a given manufacturer is unlikely and would probably not result in any guarantees.

This general specification identifies some major components that are recommended for conversion coal fine crushing cage mills. A detalled procurement specification would likely contain more design details than covered here. These could include drive design specification, assembly and erection procedures, safety devices; finish details, and performance and workmanship guarantees.

\subsection{CAGE MILL DESIGN AND CONSTRUCTION}

2.1 Cage mills will be manufacturer's normal. design for the service specified. Standard replacement parts shall be readily available.

2.2 Cage mill will be provided with quick-opening inspection doors, fitted with dust-tight seals for easy access to internals and rotor-type assemblies.

2.3 The feeder box will be designed to ensure positive penetration of feed into the cage path.

2.4 Breaker plates and impact bars will be of the reversible type to distribute wear evenly. 
2.5 All parts subject to wear will be cast in wear-resisting steel alloys.

2.6 Each rotor assembly will be balanced statically and dynamically for smooth operation.

2.7 All bearings will be heavy duty and equipped with. taconite dusttight seals.

2.8 All welding will be in accordance with the latest issue of the Structure Welding Code of the Welding Society - AWS-D1. 
GENERAL CONVEYOR SPECIFICATION

\subsection{GENERAL}

Conveyors specified in major equipment lists are really transport systems. Each conveyor system would be specially engineered, but would use standard components - belting, idlers, pulley assemblies, take-ups, drives, belt cleaners, and controls.

This general specficiation identifies some major design requirements recommended for large-capacity coal and solid refuse conveyor systems. Items covered in this specification represent only a small selection of the design requirements that would constitute the technical portion of an actual conveyor system procurement specification. The technical portion of such a specification is typically in excess of 10 pages.

\subsection{CONVEYOR SYSTEM DESIGN AND CONSTRUCTION}

\section{$2.1 \quad$ General Design Requirements}

2.1.1 The conveyor design will, in general, be based on standards adopted by CEMA (Conveyor Equipment Manufacturer's Association, 1000 Vermont Avenue, N.W., Washington, D.C. 2005, U.S.A. Reference: "Belt Conveyors for Bulk Materials", Cahners Publishing Co. Inc., Boston, Mass., 02116,U.S.A.).

2.1.2 Conveyor belt sizes and belt speeds will be established in accordance with the CEMA load cross-section tabulations and coal design data as defined in Section I Paragraph 5.0. A belt is considered 100 percent loaded when the coal is at the CEMA standard distances from the edge of the belt and angle of repose is $20^{\circ}$. Conveyor belt percentage loading will be as follows:

- For controlled feed conditions, e.g., from a belt feeder or from another cunveyor: 95 percent.

- For uncontrolled feed condition, e.g., from a reclaimer: 80 percent. 
2.1.3. Wherever possible, all conveyors will be installed in enclosed galleries and supported from the gallery ceiling. Al1 outside conveyors operating with rail-mounted stackers and reclaimers will be covered (except where interference occurs) or equipped with removable windboards.

2.1.4 Conveyor components will be specified for which replacements are readily avallable.

\subsection{Conveyor Idlers}

2.2.1 Impact 1dlers will be provided at all conveyor loading points except for tunnel reclaim conveyors and will be sized to sutt maximum load conditions in the overall conveyor system.

2.2.2 Carrying idlers will be rigid frame, $35^{\circ}$ trough, three equal rolltype minimum 6-inch-diameter rolls.

2.2.3 Transition idlers will be provided adjacent to head and tail pulleys to provide proper support of the loaded belt without excessive stress and stretch of the belt edges and will be adjustable in not over $2-1 / 2^{\circ}$ increments.

2.2.4 Training idlers will be provided, as necessary, for belt training purposes on the carrying side of fabric belts only and will be installed so as to prevent disturbance to material flow.

2.2.5 Return idlers will be of the rigid-frame-mounted, two (2) equal roll "Vee" type, with minimum $15^{\circ}$ troughing angle. The idler rolls will be mounted off-set on their respective frames to minimize build up of dribble. 


\section{2. $3 \quad$ Pulley Assemblies}

2.3.1. It is intended to have a minimum number of pulley assemblies on each conveyor. Therefore, all drive pulleys will have $180^{\circ}$ angle of wrap and snub pulleys will be provided only on secondary drives.

2.3.2 All conveyor pulleys for steel cord and fabric belting will be custom designed to the specific loads and will be flat face type. The pulleys will be of the rigid and disc design with hub construction suitable for Ringfeder type locking devices. The face of all conveyor pulleys will be 8 inches wider than the belt. The face of pulleys for belt feeders will be 6 inches wider than the bẹt.

2.3. 3 All drive pulleys will have herringbone grooved, $1 / 2$ inch thick, rubber lagging.

2.3.4 All pulley assemblies within their respective class (drive, tail, snub) will be standarized for interchangeability to the maximum extent possible.

\subsection{Take-Ups}

2.4.1 Take-ups will be located at the tail pulley wherever possible and will be carriage-mounted motorized-winch type for take-up travel over 4 feet and motorized-screw type for take-up travel of less than 4 feet.

2.4.2 Gravity or autnmatir t.ake-ilps will be installed on fabric belts, when the belt elongation does not permit the use of fixed take-up devices. Gravity or automatic take-ups will also be installed where:

- Control of curve radius is critical.

- A precision scale is installed on the conveyor.

2.4.3 Gravity take-ups will include provision for supporting the counterweight. High overhead counterweights will be avoided by the use of suspension cables. Safety guards or fences will be provided. 


\subsection{Conveyor Drives \\ 2.5.1 Drives will be located at the head end unless conveyor complexity dictates otherwise.}

2.5.2 All drives and conveyor components will be sized to start the conveyor under full design load.

2.5.3 All motors $100 \mathrm{hp}$ and below will be squirrel-cage type with fluid couplings to provide a controlled acceleration.

2.5.4 Conveyor drive motors over 100 hp will be wound-rotor type complete. with secondary resistor accelerating controls.

2.5.5 The average conveyor acceleration torque will not exceed 150 percent of the normal running torque.

2.5.6 Where required, the drive unit will have a braking system to control the coasting time and to prevent roll back.

2.5.7 All speed reducers will conform to AGMA or other buyer approval national standards, and must have helical or double heliral gears with grouind toulli faces.

\section{$2.6 \quad$ Conveyor Belting}

2.6.1 The maximum use of standardization wil1 be made for belt construction, consistent with economy of purchase and spare inventory.

2.6.2 Belting will provide adequate load support while allowing sufficicnt cransucrac flexibility.

2.6.3 Conveyor belts will be selected so that the maximum conveyor accelerating belt tension will not exceed 150 percent of the rated belt tension. 
2.6.4 Climatic conditions and material characteristics will be given careful consideration in selection of the belt. All conveyor belts will be oil and fire resistant and remain flexible at freezing temperatures.

\subsubsection{Steel Cord Belting}

(1) Steel cord belts will be selected to provide an ultimate tensile" strength of at least eight (8) times the maximum running tension calculated for each conveyor.

(2) Steel cable diameter and cable spacing will be of seller's standard design to suit the duty specified. Cable diameter and strand will be uniform throughout the entire length of the belt. Cable centers will lie in a plane parallel to the belt cover surfaces, and will not vary from this plane by more than plus minus $1 \mathrm{~mm}$. Five percent of the total cables will be allowed to exceed this tolerance by plus minus $0.5 \mathrm{~mm}$.

\subsubsection{Fabric Belting}

(1) Fabric belting will be selected to provide an ultimate tensile strength of at least 10 times the maximum running tension.

(2) Molded belt edges will be supplied on all cotton, cottonnylon, rayon, rayon-nylon beltings. Cut edge belting will be considered on other synthetic fabric beltings.

(3) Belt rubber cover thickness will be consistent with the operating conditions, type and length of belt and with economy.

\subsection{Miscellaneous}

2.7.1 Each conveyor will be furnished with a belt cleaner at the head pulley, so located that the dribble will fall into the discharge chute.

2.7.2 Expanded metal safety guards will be provided at all pulleys on the conveyor unless covered by chutes, or other means. 
2.7.3 Adjustable baffle boards will be provided at each transfer chute to regulate flow trajectory.

2.7.4 Belt vulcanizing facilities, including power, water and air supply, and access space will be provided.

2.7.5 Provision will be made to accommodate portable motorized belt reels at each conveyor for belt replacement.

2.7.6 All conveyor belts which are not installed in enrlnsed galleriee will have removable wind boards. 


\section{GENERAL GRAVIMETRIC BELT FEEDER SPECIFICATION}

\section{$1.0 \quad$ GENERAL}

Gravimetric belt feeders are specified to control discharge of coal from storage bins and silos and to measure the quantity of coal fed to conversion. Since these feeders provide the most. accurate measurement of the quantity of coal fed to conversion reactors, they should be carefully specified.

The feeder capacities specified are above or at the upper limits of current feeders. However, current gravimetric feeder designs can be applied to development of higher-capacity feeders when there is demand for such large-capacity feeders. In some situations, multiple feeders could be used in place of the single feeders specified in the major equipment lists. Use of multiple feeders would provide greater operating flexibility since partial capacity feeding would be possible while a single feèder is out of service for maintenance or calibrating. Multiple feeders would also provide greater turn-down accuracy.

This general specification identifies some major components that are recommended for conversion coal gravimetric feeders. A detailed procurement specification would probably contain more design requirements than covered here. These could include variable speed drive design specification, control-sensing system design, calibration procedures, assembly and erection procedures, finish details, and performance and workmanship guarantees.

\subsection{GRAVIMETRIC FEEDER DESIGN AND CONSTRUCTION}

2.1 Gravimetric belt feeders will be totally-enclosed feeders specially constructed for coal service.

2.2 Gravimetric belt feeder accuracy will be at least \pm 0.5 percent of design rating. 
2.3 Gravimetric belt feeders will be heavy duty type, will be horizontally, and designed for a maximum belt speed not exceeing 190 feet per minute.

2.4 All gravimetric belt feeders will have fixed screw type take-ups located at the tail pulley.

2.5 Gravimetric feeders will be provided with guide rollers for positive belt tracking and be designed for rapid belt replacement. 


\section{REFERENCES}

GENERAL

1. Coal Mine-Coal Conversion Plant Interface Evaluation and Conceptual Design, Volumes 1 and 2, Prepared by Bechtel Corporation for the Department of Energy, November 1977, FE-2370-16.

2. Letter to Bechtel from L.J.Kirby of Gulf Mineral Resources Company, Februaly 22, 1979.

3. Exxon Research and Engineering Company, "EDS Coal Liquefaction Process Development Phase IIIA," Exxon Donor Solvent Coal Liquefaction Commercial Plant Study Design, January 1978, FE-2353-13.

4. U.S. Bureau of Mines, Forecasts of Chemical, Physical, and Utilization Properties of Coal for Technical and Economic Evaluation of Coal Seams, RI 7824, 1974.

5. Coal Conversion Systems Technical Data Book, prepared for DOE by the Institute of Gas Technology, HCP/T2286-01, 1978.

6. Verner, R.A. and Sudbury, J.D., "Slagging Coal Gasification in Industry and Government," Proceedings of the Tenth Synthetic Pipeline Gas Symposium, Chicago, Illinois, October 30 - November 1, 1978.

7. Trials of American Coals in a Lurgi Gasifier at Westfield, Scotland, ERDA, FE-105, 1974.

8. Gray, R:W., "MLGW-DOE Industrial Fuel Gas Demonstration Plant," Proceedings of the Tenth Synthet1c Pipeline Gas Symposium, Chicago, Illinois, October 30 - November 1, 1978.

9. Luckie, P.T., "Developing/Modifying Coal Grinding Procedures And Equipment To Produce Predictable Size Distributions During Coal Preparation," Quarterly Progress Report For The Period April-June 1978, prepared for ERDA by Kennedy Van Saun Corp., FE-2475-22, July 15, 1978.

REFERENCES FOR TABLES 4-1, 4-2, and 4-10

1. Handbook of Gasifiers and Gas Treatment Systems, DRAVo Corporation, Pittsburgh, Pennsylvania, 1976, FE-1772-11.

2. Gray, R.W., "MLGW-DOE Industrial Fuel Gas Demonstration Plant," Proceedings of the Tenth Synthetic Pipeline Gas Symposium, Chicago, Illionois, October 30 - November 1, 1978.

3. Bloom, Ralph, Jr., "The Illinois Coal Gasification Group Project Incorporating the COGAS Process," Proceedings of the Eighth Synthetic Pipeline Gas Symposium, Chicago, Illinois, October 18 - 20, 1976. 
4. Lee, Bernard S., "Current Development of the HYGAS Program," Proceedings of the Eighth Synthetic Pipeline Gas Symposium, Chicago, Illinois, October $18-20,1976$.

5. Bair, Wilford G., "HYGAS Process Update," Proceedings of the Tenth Synthetic Pipeline Gas Symposium, Chicago, Illinois, October 30 November 2, 1978.

6. Confidential reports, Bechtel National, Inc.

7. Exxon Research and Engineering Company, "EDS Coal Liquefaction Process Development Phase. IIIA," Exxon Donor Solvent Coal Liquefaction Commercial Plant Study Design, January 1978, FE-2353-13.

8. Furlong, L.E. and Nahas, N.L., "Catalytic Coal Gasification-Process Research and Development," Proceedings of the l'enth Synthetic Pipcline Fàs Sympozium, Clllago, Il'inois, Ocluber 30 - November 1, 1978.

9. Letter to Bechtel from L.J.Kirby of Gulf Mineral Resources Company, February 22, 1979.

10. "Process Engineering Evaluations of Alternative Coal Liquefaction Concepts and a Supplemental Report on the Effect of Purchased Power and Steam Turbine Drives on the Solvent Refined Coal Process," The Ralph M. Parsons Company, EPRI Final Report AF-741, Volume 1, April 1978.

11. Patel, J.G., "Clean Fuel From Coal Is Goal of U-Gas Process," The Oil and Gas Journal, August 1, 1977, Volume 75, No. 31.

12. Eby, R.J., McClintock, N., and Bloom, R.,Jr., "The Illinois Coal. Gasification Group Project - COGAS Process," Proceedings of the Tenth Synthetic Pipeline Cas Symposium, Chicago, Illinois, October 30 November $1,1978$.

13. Bair, W.G., "Status of the HYGAS Program," Procoedings of the Ninth Synthetic Pipeline Gas Symposium, Chicago, Illinois, October 31 November 2, 1977.

14. "Synthetic Fuels," Quarterly Report, Cameron Engineers, Inc., March 1979, Volume 16, No.1.

15. Discussions with COGAS Development Company.

16. Confident1al Bechtel Study.

17. Process Engineering Evaluations of Alternative Coal Liquefaction Concepts, prepared by Ralph M. Parsons Company for EPRI, EPRI AF-741, April 1978. 


\section{TABLE REFERENCES}

1. Handbook of Gasifiers and Gas Treatment Systems, DRAVO Corporation, Pittsburgh, Pennsylvania, 1976, FE-1772-11.

2. Gray, R. W., "MLGW-DOE Industrial Fuel Gas Demonstration Plant," Proceedings of the Tenth Synthetic Pipeline Gas Symposium, Chicago, Illinois, October 30-November 1, 1978.

3. Bloom, Jr., Ralph, "The Illinois Coal Gasification Group Project Incorporating The COGAS Process," Proceedings of the Eighth Synthetic Pipeline Gas Symposium, Chicago, I11inois, October 18-20, 1976.

4. Lee, Bernard S., "Current Development of the HYGAS Program," Proceedings of the Eighth Synthetic Pipeline Gas Symposium, Chicago, Illinois, October 18-20, 1976.

5. Bair, Wilford G., "Hygas Process Update," Proceedings of the Tenth Synthetic Pipeline Gas Symposium, Chicago, Illinois, October 30November 2, 1978 .

6. Confidential reports, Bechtel National, Inc.

7. Exxon Research and Engineering Company, "EDS Coal Liquefaction Process Development Phase 111A," Exxon Donor Solvent Coal Liquefaction Commercial Plant Study Design, January 1978, FE-2353-13.

8. Furlong, L. E. and Nahas, N. C.," Catalytic Coal Gasification-Process Researeh and Development," Proceedings of the Tenth Synthetic Pipeline Gas Symposium, Chicago, Illinois, October 30-November 1, 1978.

9. Letter to Bechtel from L. J. Kirby of Gulf Mineral Resources Co., February 22, 1979.

10. "Process Engineering Evaluations of Alternative Coal Liquefaction Concepts and a Supplemental Report on The Effect of Purchased Power and Steam Turbine Drives on the Solvent Refined Coal Process," The Rilph M. Parsons Company, EPRI Final Repnrt AF-741, Volume 1, Apri1 1978. 
11. Pate1, J. G., "Clean Fuel From Coal Is Goal of U-Gas Process," The Oil and Gas Journal, August 1, 1977, Volume 75, No. 31.

12. Eby, R. J., McClintock, N. and Bloom, Jr., R., "The Illinois Coal Gasification Group Project-COGAS Process," Proceedings of the Tenth Synthetic Pipeline Gas Symposium, Chicago, Illinois, October 30November 1, 1978.

13. Bair, W. G., "Status of The HYGAS Program," Proceedings of the Ninth Synthetic Pipeline Gas Symposium, Chicago, Illinois, October 31November 2, 1977.

14. "Synethetic Fue1s," Quarterly Report, Cameron Engineers, Inc., March 1979, Volume 16, No. 1. 


\section{INTERNAL DISTRIBUTION}

1. P. K. Carlson

2. D. A. Dyslin

3. D. M. Eissenberg

4. J. R. Horton

5. J. E. Jones, Jr.

6. W. A. McAuley

7. R. E. MacPherson

8. B. Niemann

9-28. L. F. Parsly
29. M. D. Silverman

30. 0. W. Thomas

31. F. C. Zapp

32. ORNL Patent Office

33. Central Research Library

34. Document Reference Section

35-36. Laboratory Records Department

37. Laboratory Records, ORNL RC

\section{EXTERNAL DISTRIBUTION}

Department of Energy, Washington, DC 20545

38. T. K. Lau

39. J. L. Powell

40. K. Youssef

DOE Oak Ridge Operations Office, Oak Ridge, TN 37830

41. Office of Assistant Manager for Energy Research and Development

DOE Morgantown Energy Technology Center, P.0. Box 880, Morgantown, WV 26505

42. Don Freeburn

43. Fred V. Karlson, Bechtel National, Inc., P.0. Box 3965, San Francisco, CA 94119

44-45. Technical Information Center, Oak Ridge, TN 37830 